\title{
A MULTI-COUNTRY STUDY OF HOUSEHOLD ENERGY SAVING BEHAVIOUR
}

by

Ela Tabaku, B.Sc., University of Manitoba, 2009

\author{
A project paper \\ presented to Ryerson University \\ in partial fulfillment of the \\ requirements for the degree of \\ Master of Applied Science \\ in the Program of \\ Environmental Applied Science and Management \\ Toronto, Ontario, Canada, 2015 \\ (C) Ela Tabaku 2015
}




\section{AUTHOR'S DECLARATION}

I hereby declare that I am the sole author of this project paper. This is a true copy of the project paper, including any required final revisions.

I authorize Ryerson University to lend this project paper to other institutions or individuals for the purpose of scholarly research.

I further authorize Ryerson University to reproduce this project paper by photocopying or by other means, in total or in part, at the request of other institutions or individuals for the purpose of scholarly research.

I understand that my project paper may be made electronically available to the public. 


\title{
A MULTI-COUNTRY STUDY OF HOUSEHOLD ENERGY SAVING BEHAVIOUR
}

\author{
Ela Tabaku, 2015 \\ Master of Applied Science \\ Environmental Applied Science and Management \\ Ryerson University
}

\begin{abstract}
Due to the increased worldwide demand for electricity, governments and policy makers are looking to identify tools to help reduce household energy consumption. This study examines the relationship between the empirical and attitudinal variables and the likelihood of implementation of household energy conservation measures and investments, using a wide data set involving household level characteristic from 10,252 respondents from ten different countries (Australia, Canada, Czech Republic, France, Italy, Korea, Mexico, Netherlands, Norway, and Sweden). Moreover, the effects of time varying electricity pricing on household energy saving measures and investments is evaluated. Using the multivariable probit model, this project makes comparison across the ten countries incorporating socio-demographic characteristics, and allows for the potential correlation between energy saving decisions (measures and investments).
\end{abstract}




\section{ACKNOWLDEGEMENTS}

First and foremost, I would like to thank my supervisor, Dr. Paul Missios, for the continued help and guidance throughout this work. His support is very much appreciated and I am grateful for the knowledge he has passed on.

I would also like to thank my parents who instilled in me the desire to learn and made many sacrifices so I would have access to a better education and future. 


\section{TABLE OF CONTENTS}

List of Tables ............................................................................................................................

List of Figures........................................................................................................................................ix

List of Appendices.........................................................................................................................................

Acronyms and Abbreviations ...................................................................................................................

1. INTRODUCTION.........................................................................................................................1

1.1.Project Objectives …………………………………...........................................

1.2.Project Questions ..................................................................................................

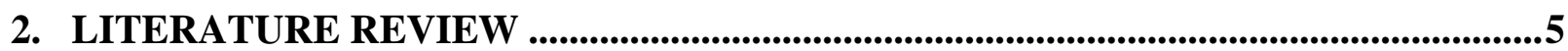

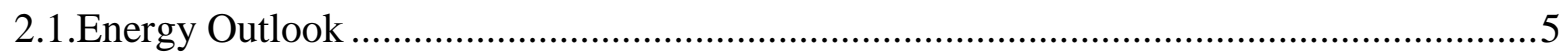

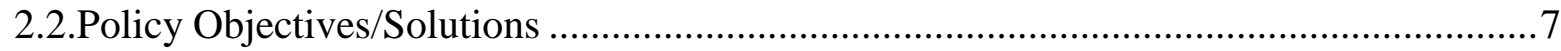

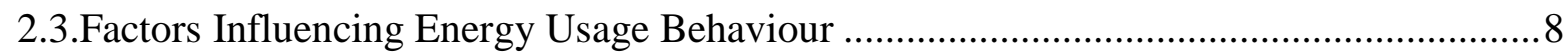

2.3.1. Socio-demographic Factors .....................................................................11

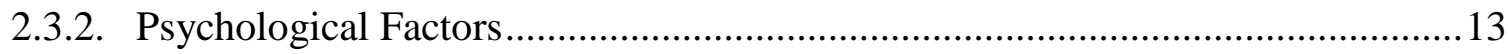

2.3.3. External Factors - Demand Response.............................................................. 14

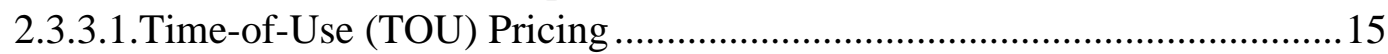

3. EMPIRICAL FRAMEWORK .................................................................................................20

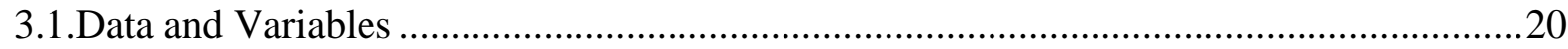

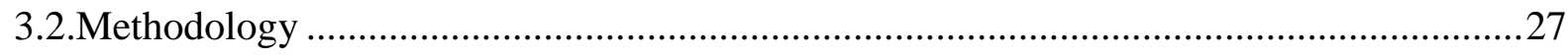

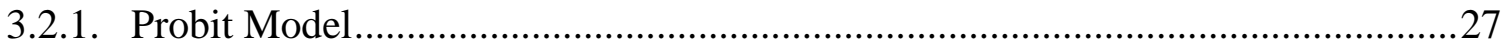

3.2.2. Multivariate and Univariate Probit Analysis of the Effects of Individual

Characteristics, Household Characteristics and Policy Variable on Measures

and Investments ................................................................................................ 30

3.2.3. Probit Analysis of the Effects of Environmental Concern on Renewable

Energy Purchase ............................................................................................. 31

3.2.4. Multivariate Probit Analysis of the Effects of Motivators on Measures and

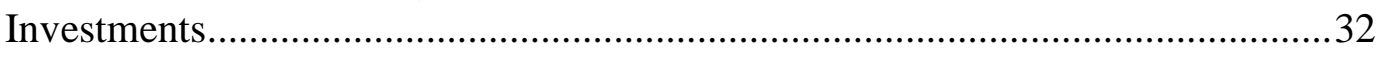

3.2.5. Empirical Analysis of Motivators ......................................................................3

4. RESULTS AND DISCUSSION .................................................................................................34

4.1.Multivariate and Univariate Probit Analysis of the Effects of Individual, Household and Policy Variable on Measures and Investments...........................................................34

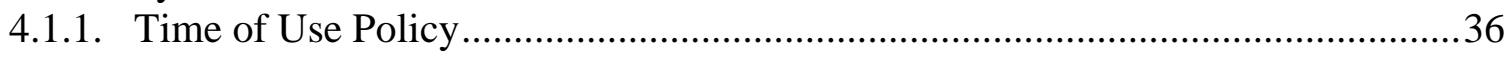

4.1.2. Country Specific Characteristics ......................................................................38

4.1.3. Individual and Household Characteristics..............................................................39

4.2.Probit Analysis of the Effects of Environmental Concern on Renewable Energy

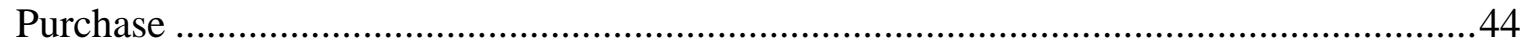


4.3.Multivariate Probit Analysis of the Effects of Motivators on Measures and

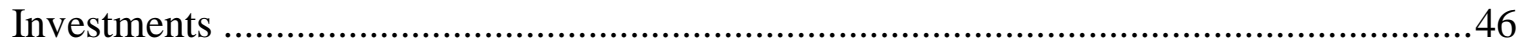

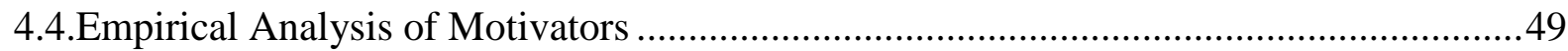

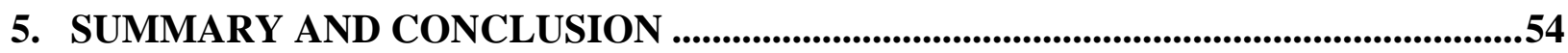

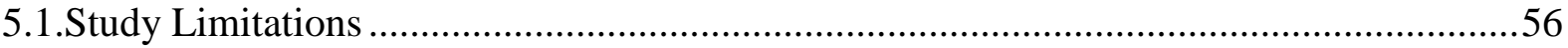

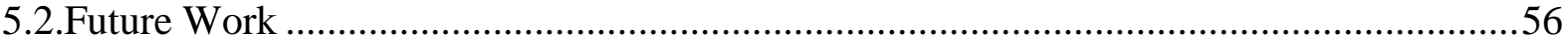

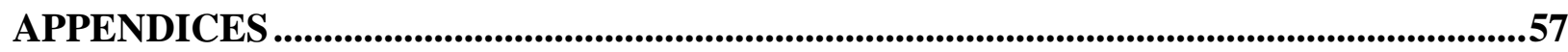

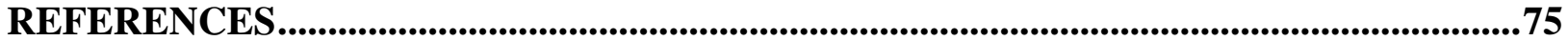




\section{LIST OF TABLES}

Table 2.1 - Key Development in Energy Policy in IEA countries (IEA, 2012). The table marks (x) each country that has implemented a program on each of the six areas of energy policy, with short description of key programs in some of the relevant countries to this research paper

Table 2.2 - Summary of key papers that consider the influence of socio-demographic variables in energy consumption and conservation ..... 18

Table 3.1 - Observations removed for the five different variables .22

Table 3.2 - Number of surveys used in this analysis after the removal of "blank" and "don't know" observations

Table 3.3 - Definition and description of explanatory variables 23

Table 3.4 - Summary statistics for all variables

Table 3.5 - Description of the independent variables used in the analysis of the relationship between purchase of renewable energy and environmental concern

Table 3.6 - Description of the independent variables used in the analysis of the relationship between purchase of renewable energy and environmental concern.

Table 4.1 - Comparison of coefficients from multivariate and univariate binary probit estimation results for energy efficient measures. Statistically insignificant results are marked in red

Table 4.2 - Comparison of coefficients from multivariate and univariate binary probit estimation results for energy efficient investments. Statistically insignificant results are marked in red

Table 4.3 - Results of multivariate probit evaluation of effect of environmental concern on renewable energy purchase. Values in red represent statistically insignificant results

Table 4.4 - Summary of the effects of motivators on Measures and Investments. (+) indicates a positive effect; (-) indicates a negative effect; and (x) indicates an insignificant effect

Table 4.5 - Summary of results of empirical analysis of motivators. Number of participants for each motivator is the number of participants surveyed that claimed that the motivator was fairly and very important

Table A1 - Results of multivariate probit analysis of motivators describing the relation of motivators and energy saving measures

Table A2 - Results of multivariate probit analysis of motivators describing the relation of motivators and energy saving investments 
Table B1 - Multivariate binary probit estimation results for energy efficient measures............58

Table B2 - Multivariate binary probit estimation results for energy efficient investments ........59

Table B3 - rho values from multivariate binary probit model ............................................60

Table C1 - Univariate binary probit estimation results for energy efficient measures ..............61

Table C2 - Univariate binary probit estimation results for energy efficient investments ..........62

Table D1 - Multivariate binary probit estimation results for energy efficient measures for

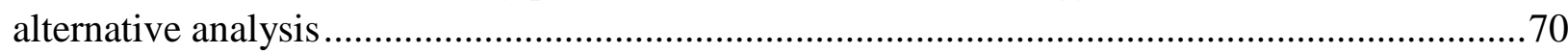

Table D2 - Multivariate binary probit estimation results for energy efficient investments for alternative analysis .......................................................................................... 71

Table D3 - rho values from multivariate binary probit model for alternative analysis ..............72

Table D4 - Univariate binary probit estimation results for energy efficient measures for

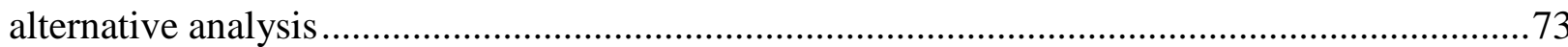

Table D5 - Univariate binary probit estimation results for energy efficient investments for

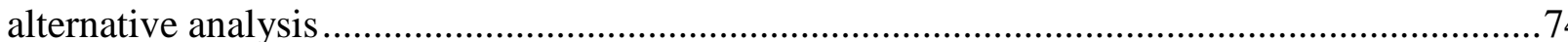




\section{LIST OF FIGURES}

Figure 2.1 - Household electricity consumption per capita (WEC, 2008) …………..................5

Figure 2.2 - World energy consumption by sector for year 2011 (EIA, 2015) ...........................6

Figure 2.3 - Residential energy use in Canada for year 2007 (NRCan, 2010)............................6

Figure 2.4 - Ontario time-of-use electricity chart indicating the varying electricity prices charged depending on the time of use. During on-peak hours the price is almost double the price during off-peak hours ("Electricity Prices," 2014) ............................................................ 16

Figure 3.1 - Number of respondents for each group of individual characteristic variables ........24

Figure 3.2 - Percent participation of each country in energy efficient measures ........................26

Figure 3.3 - Percent participation of each country in energy efficient investments....................26

Figure 3.4 - Model used in the study of the effect of policy and background variables on energy saving measures and investments through the multivariate probit regression.....

Figure 4.1 - Effects of varying electricity pricing on energy saving measures and investments using the multivariate and univariate probit model

Figure 4.2 - Results of probit model, evaluating the relationship between environmental concerns and purchase of renewable energy. The bars in red indicate statistically insignificant results

Figure 4.3 - Multivariate probit analysis of the relationship of motivators and energy saving measures and investments. Positive coefficients indicates that households that consider the motivators important are more likely to partake in energy saving measures and investments. The greater the coefficient the stronger the relation. Bars in black color indicate statistically insignificant results

Figure 4.4 - Importance of selected motivators as factor to reduce energy consumption. Prices obtained from IEA, 2012 and Simshauser, Nelson, \& Doan, 2010 (Price for Australia is the average of Queensland (QLD) and New South Wales (NSW)) ..

Figure 4.5 - Energy consumption per capita (year 2008) and price of electricity (US $\$$ MWh) for year 2008

Figure D1 - Effects of varying electricity pricing on energy saving measures and investments using the multivariate and univariate probit model..... 


\section{LIST OF APPENDICES}

Appendix A - Results of multivariate probit analysis of motivators.....................................57

Appendix B - Results of multivariate binary probit for energy efficient measures and investments .58

Appendix C - Results of univariate binary probit for energy efficient measures and investments 61

Appendix D - Alternative analysis

D.1. Multivariate and Univariate Probit Evaluation of the Effects of Individual, Household and Policy Variable on Measures and Investments.....................................63

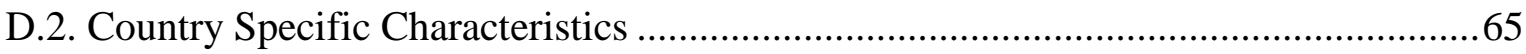

D.3. Individual and Household Characteristics ..........................................................66

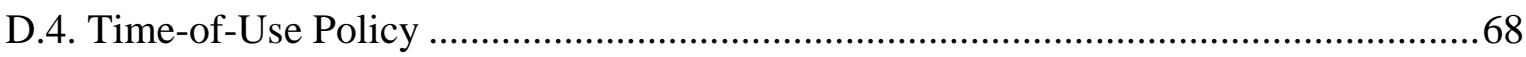




\section{ACRONYMS AND ABBREVIATIONS}

ASEAN The Association of Southeast Asian Nations

CIS Commonwealth of Independent States

CPP Critical Peak Pricing

DR Demand Response

ED-CPP Extreme Day CPP

EDP Extreme Day Pricing

EEO Energy Efficiency Opportunities

EIA U.S. Energy Information Administration

EU European Union

IBP Incentive-Based Programs

IEA The International Energy Agency

MtC Millions of metric tons of carbon

NRCan Natural Resources Canada

OECD The Organisation for Economic Co-operation and Development

PBP Price-Based Programs

RTP Real Time Pricing

TOU Time-of-Use 


\section{CHAPTER 1: INTRODUCTION}

The continued increase in energy consumption, due to population and economic growth, represents a major concern to governments, policy makers, and the public, as it is linked to many environmental issues that are causing a toll on Earth's natural resources. More and more fossil fuels are burned at an increasing rate to sustain our way of life and advance the economies of developing countries. The increased energy demand has led to the unsustainable extraction of natural resources and has exposed the need for the reduction and eventual elimination of our dependence on non-renewable natural resources.

A growing cause of environmental damage in industrialized countries is household expenditure (Michaelis, 2003). Worldwide household energy consumption has increased by $20 \%$ from 1990 to 2006, accounting for $17 \%$ of World's energy consumption. On average the residential sector accounts $20 \%$ to $35 \%$ of a country's energy use (OECD, 2001), and in the United States it accounted for 39\% of the country's $\mathrm{CO}_{2}$ emission for year 2006 (EIA, 2008). The vast impact that household energy consumption has on the environment demonstrates the need for policy instruments meant to increase household energy saving and transform household into more sustainable ones. Household energy conservation activities have received a great deal of attention by governments, and different policies are being introduced to direct peoples' decisions towards more environmentally friendly ones. As noted in Michaelis (2003), surveys of public opinion show that there is an interest for action to address environmental problems, ranging from changes in lifestyle to technological progress. Many approaches are used by governments to target energy consumption behaviour, and they include taxation, tax incentives, education, communication campaigns, and a combination of different policy instruments (IEA, 2012). These policies can prove beneficial in altering behaviour; however, it is important to note 
that altering behaviour is a complex matter, and the impact of socio-demographic, psychological, and external factors should be considered when selecting a policy instrument.

Socio-demographic factors such as income, age, gender, education, and employment have been found to impact the likelihood of a household adopting energy saving measures and investments. While age and gender do not seem to be good predictors of household energy consumption (Nair, et al., 2010 \& Gatersleben, et al., 2002), income and employment are among the strongest socio-demographic factors that influence residential energy use (Abrahamse \& Steg, 2009). Moreover, residential consumers that are concerned about the environment are more willing to pay a higher fee for renewable energy (Bang et al., 2000; Kim \& Choi, 2005). Studies have found that customers respond to changes in electricity price, but the magnitude of response varies greatly from study to study (Faruqui \& Sergici, 2010). Policy instruments that address pricing, such as time-of-use (TOU) pricing, are beneficial to both the consumer and the producer, and have been shown to influence household energy usage behaviour (Faruqui, et al., 2013 \& Yang, et al., 2013).

The differences in energy usage due to electricity pricing, socio-demographic factors, and psychological factors, suggest that policies should be selected in such a way that they are successful in changing the behaviour of the population they are targeting. To achieve the desired results it is necessary to understand the effects that the characteristics of a certain group, such as an income class or a particular country, have on the likelihood of adopting energy saving activities, and design policies that specifically target each group. 


\subsection{Project Objectives}

The purpose of this research is to evaluate the relationship between the empirical and attitudinal variables and the likelihood of implementation of household energy conservation measures and investments. More specifically this paper will:

assess the relationship between time-of-use (TOU) policy and households' energy saving measures and investments

assess the relationship between environmental concern on the likelihood of households' purchasing renewable energy

$>$ assess the relationship between different motivators and energy saving measures and investment

Many studies perform a direct relationship between the variables without accounting for the effect that the rest of the variables have on the results, which in turn can lead to skewed conclusions. For example, the OECD (2011) study shows that having metered electricity has an impact on energy-saving investments such as energy-efficient appliances or thermal insulation, but it does not take into account that these investments may not be a direct effect of the policy, rather than an effect of being from a certain country, age group, or income class. The purpose of this study is to provide insight on the effects of time-of-use pricing policy on energy saving activities, while controlling for the effects of background variables. These results can then be used as a lesson to indicate the importance of controlling for the influences of other variables when assessing the relationship between variable and outcome. 


\subsection{Project Questions}

The research questions this project with seek to answer are:

$>$ What is the relation between time-of-use (TOU) electricity pricing and households' energy saving measures and investments?

$>$ Is individual's concern over environmental issues related to likelihood of households' purchasing renewable energy from electricity provider?

$>$ What is the relationship between what people consider a motivator for energy saving and the households' energy saving measures and investment? 


\section{CHAPTER 2: LITERATURE REVIEW}

\subsection{Energy Outlook}

The average electricity consumption per capita in both developed and developing countries has been steadily increasing and is expected to increase even more so in the future as world population continues to grow. As seen in Figure 2.1, there has been a drastic increase in household energy consumption per capita in all regions from 1980 to 2006 and this demand is expected to continue to increase. Such an increase in energy demand will place a strain on the environment and will likely lead to irreversible environmental damage through the release of greenhouse gasses and depletion of natural resources.

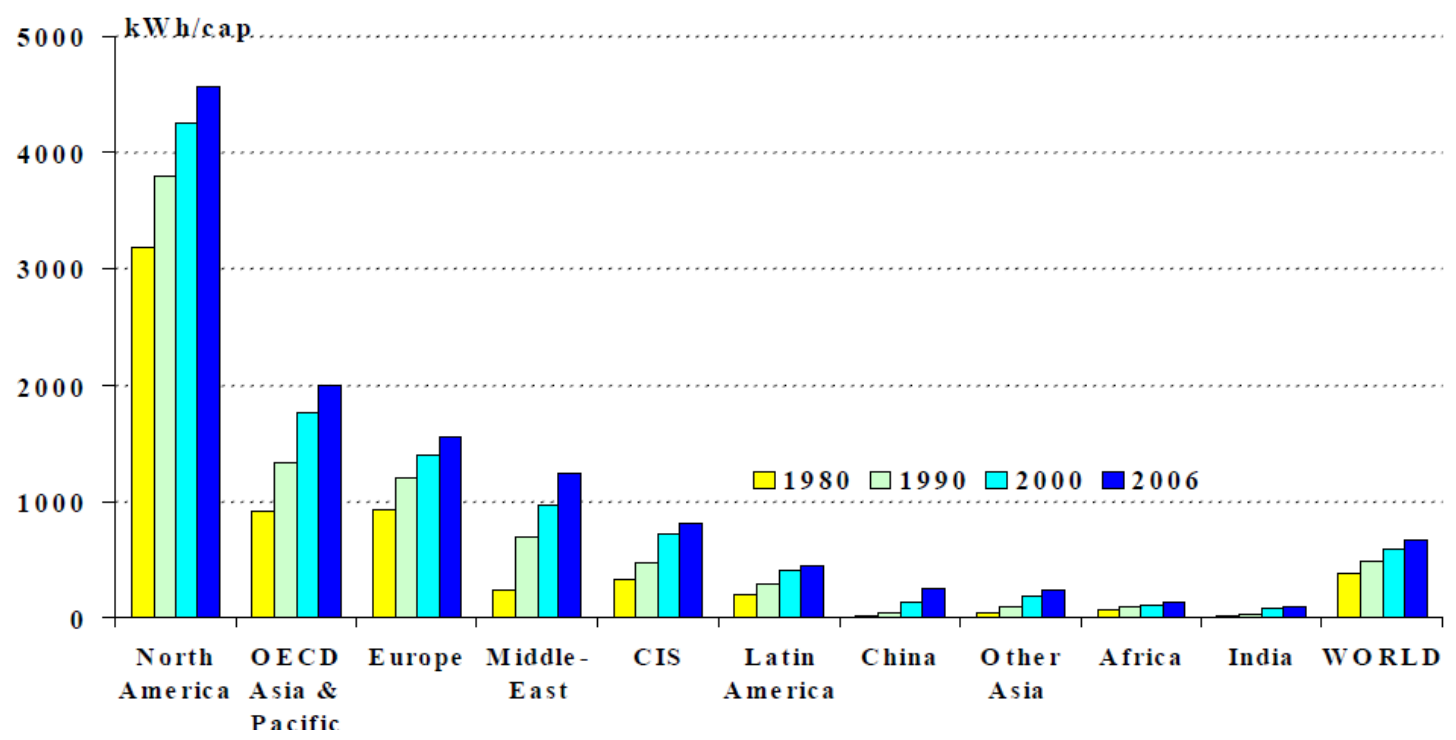

Figure 2.1. Household electricity consumption per capita (WEC, 2008). North America includes US and Canada; OECD Asia \& Pacific includes Japan, Korea, Australia and New Zealand; Europe includes EU, Albania, Bosnia, Croatia, Iceland, Macedonia, Norway, Serbia, Switzerland, and Turkey; CIS (Commonwealth of Independent States) includes countries of the former Soviet Union excluding the Baltic States (i.e. Estonia, Latvia and Lithuania); Other Asia includes ASEAN and other South Asia.

In developing countries, the increase in energy demand is directly linked to the projected rise in population and the standards of living (EIA, 2013). On the other hand, in industrialized 
countries, the fastest growing cause of increased energy expenditure and greenhouse gas emissions is lifestyle and consumption (Michaelis, 2003). Worldwide household energy consumption increased by $20 \%$ from 1990 to 2006, accounting for $20 \%$ of $\mathrm{CO}_{2}$ emissions (OECD, 2011) and 17\% of world energy expenditure, as shown in Figure 2.2. As noted by Kelly (2012), there are substantial variations in consumption between countries; for example, World Bank data for the energy consumption for year 2008 showed countries such as Norway, Canada and Sweden had a higher per capita consumption than Mexico, Italy and Czech Republic (World Bank, 2014). In Canada, heating accounted for $81 \%$ of residential energy use for year 2007, followed by appliances, lighting and cooling (Figure 2.3). Decreasing household energy usage is important both because of the current extensive use and because of the expected growth. Therefore, promoting household energy reduction and energy efficiency has the potential of significantly contributing to a decrease in the world's energy consumption and greenhouse gas emissions (Kallbekken, Saelen, \& Hermansen, 2013).

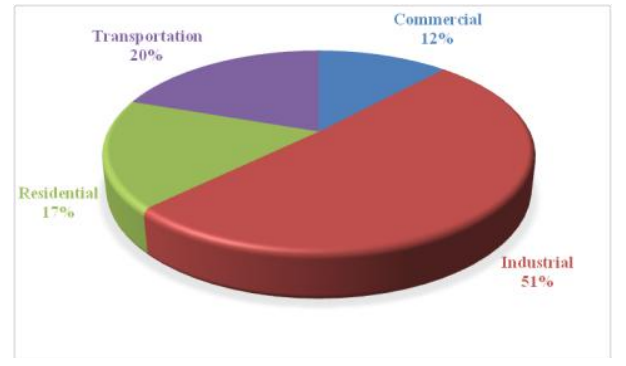

Figure 2.2: World energy consumption by sector for year 2011 (EIA, 2015)

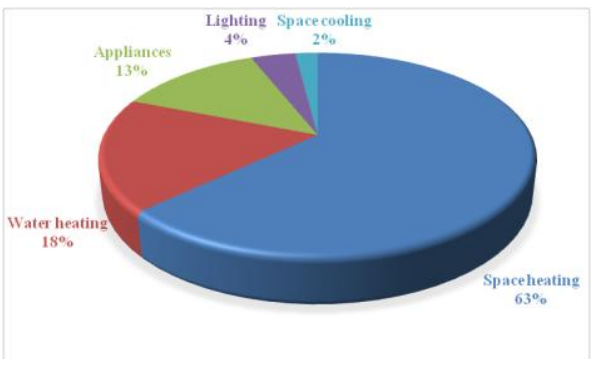

Figure 2.3. Residential energy use in Canada for year 2007 (NRCan, 2010)

Literature shows that strategies such as decreasing water heater temperature, switching electricity to standby, and installing energy efficient appliances lead to a decrease in energy use (Levine, M. et al., 2007). One study in particular calculates this possible reduction in terms of 
reasonably achievable carbon emission reduction (RAER), noting that a decrease in RAER of $5.1 \%$ of the total household use or $32 \mathrm{MtC}$ (millions of metric tons of carbon) can be attained by undertaking activities such as home insulation and upgrades of heating and cooling equipment (Dietz, et al., 2009). Newsham and Donnelly (2013) have also found that replacing old space heating systems with new ones can lead to energy savings of about 2,000 kWh/year (Newsham \& Donnelly, 2013). Moreover, partaking in activities such as changing water heaters and laundry temperature can lead to a decrease in RAER of $0.21 \%$ (or $1.2 \mathrm{MtC}$ ), and daily use behaviour, such as changing electricity to standby, decreasing thermostat temperature, and line drying can lead to a combined decrease in RAER of $1.58 \%$ (or $9.9 \mathrm{MtC}$ ) (Dietz, et al., 2009). These findings make evident the significant impact that simple daily measures could have in decreasing energy consumption and greenhouse gas emissions.

\subsection{Policy Objectives/Solutions}

Governments around the world have implemented policy objectives meant to decrease energy consumption and promote renewable energy use. These policies tend to focus on buildings, appliances, lighting, transport, industries, and utilities, and usually address a combination of areas (IEA, 2011). Policy instruments vary widely and selection of an adequate instrument is a key factor in its success. The International Energy Agency (IEA) (2012) summarizes key developments in energy policies from the 28 IEA countries. As shown in Table 2.1, IEA group members have created policies that fall under six sections: general energy policy, energy efficiency, electricity, research and development, renewable, and oil and gas. Among the countries considered in this paper, more have engaged in energy efficiency and electricity policies. With regards to energy efficiency, Australia has created the Energy Efficiency 
Opportunities (EEO) Program that aims to make industry more energy efficient and involves the analysis of energy data and a systematic process to identify opportunities for energy efficiency. Canada, on the other hand, continues to increase the standards for commercial building energy codes (IEA, 2012). Other programs implemented by the countries used in this study are presented in Table 2.1. Most policies introduced aim at increasing efficiency, reducing consumption and emissions, and increasing environmental protection. To achieve these policy objectives, many countries have implemented policy instruments aimed at swaying people's behaviour towards energy conservation. In order to select the most appropriate policy tool, it is important to consider the factors that influence energy usage behaviour.

\subsection{Factors Influencing Energy Usage Behaviour}

A wide range of strategies are proposed to decrease energy consumption. These include simple measures, such as switching the lights off when not in use or monitoring electricity expenditure, and more complex ones such as investing in energy efficient equipment and modifying behaviour (Levine, M. et al., 2007). While some of these measures are based on attitudinal factors, others, such as investing in energy efficient appliances, require significant monetary cost and are not likely to be implemented in households based on psychological or moral factors alone (Urban \& Scansy, 2012). Identifying what motivates people to decrease energy consumption and increase energy saving behaviour is complex, and depends not only on socio-demographic factors, but also on peoples' attitudes, preferences, and electricity prices. A literature review of the impacts of some of the main socio-demographic, psychological, and external factors relevant to this study is tabulated in Table 2.2 and described in the following sections. 
Table 2.1. Key Development in Energy Policy in IEA countries (IEA, 2012). The table marks (x) each country that has implemented a program on each of the six areas of energy policy, with short description of key programs in some of the relevant countries to this research paper. Continued in page 10.

\begin{tabular}{|c|c|c|c|c|c|c|}
\hline Country & General Energy Policy & Energy Efficiency Policy & Electricity Policy & $\begin{array}{c}\text { Energy } \\
\text { Research and } \\
\text { Development }\end{array}$ & Renewables & $\begin{array}{c}\text { Oil and } \\
\text { Gas }\end{array}$ \\
\hline Australia & & $\begin{array}{l}\text { Energy Efficiency Opportunities } \\
\text { (EEO) Program } \\
\text { - systematic process to identify } \\
\text { opportunities for energy efficiency }\end{array}$ & $\begin{array}{l}\text { National Electricity } \\
\text { Market (NEM) } \\
\text { - improve energy } \\
\text { market governance }\end{array}$ & & & \\
\hline Austria & & & $\mathrm{X}$ & & $\mathrm{X}$ & $\mathrm{X}$ \\
\hline Belgium & & & $\mathrm{X}$ & & & \\
\hline Canada & $\begin{array}{l}\frac{\text { Responsible Resource }}{\text { Development (RRD) }} \\
\text { - more effective and efficient } \\
\text { regulatory system } \\
\text { - strengthening environmental } \\
\text { protection }\end{array}$ & $\begin{array}{l}\text { National Energy Code } \\
\text { of Canada for Buildings } 2011 \\
\text { - minimum requirements for the } \\
\text { design and construction of energy } \\
\text { efficient new commercial buildings }\end{array}$ & & & & \\
\hline Czech Republic & $\begin{array}{l}\text { Czech State } \\
\text { Energy Concept (SEC) } \\
\text { re-direct available coal into heating } \\
\text { and highly effective co-generation } \\
\text { systems and find alternative fuels }\end{array}$ & & & & & \\
\hline Denmark & & $\mathrm{X}$ & & & $\mathrm{X}$ & \\
\hline Finland & & & $\mathrm{X}$ & & & \\
\hline France & & & & $\mathrm{X}$ & & \\
\hline Germany & $\mathrm{X}$ & & $\mathrm{X}$ & & & \\
\hline Greece & & & $\mathrm{X}$ & & & \\
\hline Hungary & & & $\mathrm{X}$ & & & \\
\hline Ireland & & $\mathrm{X}$ & & & & $\mathrm{X}$ \\
\hline Italy & & $\begin{array}{l}\text { White Certificates (WhCs): } \\
\text { - reduce GHG emissions } \\
\text { - reduce energy import dependence } \\
\text { - develop market for energy } \\
\text { efficiency products and services. }\end{array}$ & & $\mathrm{X}$ & & $\mathrm{X}$ \\
\hline
\end{tabular}


Table 2.1. Key Development in Energy Policy in IEA countries (IEA, 2012). The table marks (x) each country that has implemented a program on each of the six areas of energy policy, with short description of key programs in some of the relevant countries to this research paper. Continued from page 9.

\begin{tabular}{|c|c|c|c|c|c|c|}
\hline Country & General Energy Policy & Energy Efficiency Policy & Electricity Policy & $\begin{array}{c}\text { Energy } \\
\text { Research and } \\
\text { Development }\end{array}$ & Renewables & $\begin{array}{c}\text { Oil and } \\
\text { Gas }\end{array}$ \\
\hline Japan & & $\begin{array}{l}\text { Rational Use of Energy } \\
\text { - improve the thermal } \\
\text { insulation performance }\end{array}$ & & & & $\mathrm{X}$ \\
\hline Korea & & & $\begin{array}{l}\text { The Drill } \\
\text { - } 20 \text { min blackouts } \\
\text { - voluntary emergency exercise in } \\
\text { which all energy stakeholders } \\
\text { were encouraged to participate } \\
\text { to save electricity }\end{array}$ & $X$ & & \\
\hline Luxemburg & & $\mathrm{X}$ & & & & \\
\hline Netherlands & $\begin{array}{l}\text { National Co-ordination } \\
\text { Procedure } \\
\text { - spatial decision-making is therefore } \\
\text { done at the national level }\end{array}$ & & & & $\mathrm{X}$ & \\
\hline New Zealand & & $\mathrm{X}$ & $\mathrm{X}$ & & & \\
\hline Norway & & & & & $\mathrm{X}$ & $\mathrm{X}$ \\
\hline Poland & & & & & & $\mathrm{X}$ \\
\hline Portugal & & $\mathrm{X}$ & & & & $\mathrm{X}$ \\
\hline Slovak Republic & & $\mathrm{X}$ & & & & \\
\hline Spain & & & & & $\mathrm{X}$ & \\
\hline Sweden & $\begin{array}{l}\text { Climate and Energy Policy Package } \\
\text { - purchase of environment-friendly } \\
\text { - vehicles } \\
\text { - tax exemption on high-ratio blends } \\
\text { of renewables into gasoline and } \\
\text { diesel fuels } \\
\text { - promote biofuels and development } \\
\text { and deployment of clean vehicles }\end{array}$ & & & & $\mathrm{X}$ & \\
\hline Switzerland & & & $\mathrm{X}$ & & & \\
\hline Turkey & & $\mathrm{X}$ & & & & \\
\hline United Kingdom & & $\mathrm{X}$ & $\mathrm{X}$ & & & \\
\hline United States & $\mathrm{X}$ & & & & & \\
\hline
\end{tabular}




\subsubsection{Socio-demographic Factors}

\section{Age}

Age does not seem to be a good predictor of household energy use. Studies have shown that younger participants are more likely to invest in energy saving technology. Older homeowners, on the other hand, were are likely to adopt energy saving measures, which may be due to the lower income of the older participants, or the lack of knowledge about energy efficient measures and investments (Nair, et al., 2010). Moreover, Gatersleben, et al. (2002) failed to find a relationship between age and energy consumption or saving. In contrast, Long (1993) found that homeowners older than 65 years made significant energy efficient investments, and Barr et al. (2005) reported that respondents with a mean age of 55 years are more likely to undertake both energy-efficient investments and measures than younger age groups.

\section{Gender}

As with age, the effects of gender on energy usage behaviour are inconsistent among studies. Kollmuss and Agyeman (2002) and Zelezny, et al., (2000) found that women have a higher environmental concern and are more willing to change. Other research has found that gender is not a good predictor of energy saving behaviour (Sardianou, 2007; Poortinga et al., 2003), and especially when other background factors, such as income and household characteristics, are accounted for (Clark, et al., 2003).

\section{Education}

Participants with a lower education level are more likely to adopt behavioural measures (such as switching off the lights when not in use or line drying of laundry), but they are less 
likely to participate in technical measures (i.e. energy-efficient heating system or house insulation) (Poortinga et al., 2003). More highly educated people are more likely to display environmental friendly behaviour, and have lower household energy use (Poortinga, et al., 2004; Gatersleben, et al., 2002). Other studies have found that the education and income of the main wage earner of the family has no significant influence on the number of energy conservation actions taken by the household (Curtis, et al., 1984; Sardianou, 2007).

\section{Employment of occupants}

Employment of household occupants (full-time, part-time, retired, etc.) directly impacts household income and therefore indirectly impacts energy consumption. Participants in full-time employment have more disposable income and therefore are more likely to invest in energy saving technology. Moreover, they spend less time at home which leads to a lower consumption level. As found by Powers, et al., (1992) full-time employment is related to household energy conserving investments.

\section{Household Income and Size}

Household income is one of the strongest socio-demographic factors to influence residential energy use behaviour. Research has shown that households with higher income and larger size tend to use more energy, suggesting that availability and need shape energy consumption rather than only psychological or altruistic factors such as protecting the environment (Abrahamse \& Steg, 2009; OECD, 2008b; O’Neill \& Chen, 2002). In addition Abrahamse and Steg (2009) demonstrate that direct energy use (gas, electricity and fuel) was related to household size (number of people in the household), while indirect energy use (from 
production, consumption and disposal of goods) is related to both income and household size. These results are supported by the findings of Poortinga, et al. (2004) and Gatersleben, et al. (2002) showing that larger households and households with higher income have a higher energy use. While larger household have a higher energy use they have a lower per capita consumption. O’Neill and Chen (2002) found that a two-person household uses $17 \%$ less energy per person than a single-person household.

As discussed in Cayla, et al. (2011), households with lower income are less likely to invest in energy efficient equipment. However, this study also indicated that high income households are also not likely to invest in energy saving equipment (Cayla, Maizi, \& Marchand, 2011). This observation does not agree with what would be expected, since it is believed that high income households have the necessary capital to invest in energy efficient technology. One possible explanation could be that the high income households do not perceive the benefits gained from investing in energy efficiency to outweigh the upfront investment. Perhaps this inconsistency can be overcome by raising electricity prices and therefore increasing the perceived benefit of energy efficient investments.

\subsubsection{Psychological Factors}

Understanding of environmental issues could be a powerful incentive that could lead homeowners to purchase a greater amount of renewable energy and increase energy savings. Abrahamse and Steg (2009) found that energy savings are influenced by psychological factors, and the more concerned people are about the environment, the more they are willing to pay for renewable energy (Bang et al., 2000; Kim \& Choi, 2005). Other research supports these findings, showing that environmental knowledge and the belief that energy sources have consequences on 
the environment is positively related to the likelihood of purchasing green energy (Rowlands, et al., 2003; Mostafa, 2007; Bang et al., 2000). Moreover, Abrahamse and Steg (2009) found that the more the respondents they surveyed thought they were capable of saving energy, the more they tended to save. On the other hand, there are studies that have not found the association between psychological factors and energy demand to be very strong (OECD, 2008b). Gatersleben, et al. (2002) and Axelrod and Lehman (1993) indicated that environmental concern is not a significant factor that influences energy consumption or that leads to environmental friendly behaviour.

\subsubsection{External Factors - Demand Response}

Demand Response (DR) programs are employed to provide users with incentives so that the energy load is shifted from peak to off-peak hours. Consumers can respond to the high electricity prices by reducing their electricity consumption during peak hours or by shifting their consumption from peak hours to off-peak hours (Albadi \& El-Saadany, 2008). According to U.S. Department of Energy, Demand Response can be defined as "changes in electric usage by enduse customers from their normal consumption patterns in response to changes in the price of electricity over time" (DOE, 2005). DR programs have the potential to benefit the consumer who will enjoy a lower electricity bills. Moreover, these programs can lead to a decrease of the market electricity price because of the more efficient use of the infrastructure and can lower the risk of electricity outages (Albadi \& El-Saadany, 2008).

DR programs can be Incentive-Based Programs (IBP) and Price-Based Programs (PBP). PBPs are based on consumers voluntarily reducing their demand in response to market prices and can be quite advantageous in reducing or shifting electricity consumption (Muratori, et al., 2014; 
Albadi \& El-Saadany, 2008). This program includes: Time of Use (TOU) rate, Critical Peak Pricing (CPP), Extreme Day Pricing (EDP), Extreme Day CPP (ED-CPP), and Real Time Pricing (RTP) (Muratori, et al., 2014; Albadi \& El-Saadany, 2008). Yuan, et al. (2010) found that higher energy prices have the potential to decrease energy consumption in China in both the industrial and household sectors. Moreover, Reiss and White (2008) found that in year 2000, after the rapid increase in electricity prices in California, there was a decrease of $13 \%$ in the average household electricity over 60 days. This paper will look at time-of-use (TOU) electricity pricing, where households pay a lower electricity price during off-peak period and a higher price during peak period.

\subsubsection{Time-of-Use Pricing (TOU)}

The main purpose of time-of-use pricing (TOU) is to provide an incentive for users to reduce consumption during periods where supply is low and prices are high. On the other hand, flat electricity prices fail to provide pricing that reflects the marginal cost of providing power and gives no incentive to end-users to reduce or shift consumption. Households have been shown to respond to economic incentives (OECD, 2008b), and as such varying electricity prices were introduced to decrease consumption during peak hours. Many countries around the world, and especially the European Union (EU) member states, have implemented some legal framework for the installation of smart metering. As discussed in the European Smart Metering Landscape Report, countries such as France, Italy, Norway, and Sweden are among the countries with a strong path to the full implementation of smart metering (Renner, 2011).

An example of TOU pricing in Ontario is shown in Figure 2.4. During off-peak hours (from $7 \mathrm{pm}$ to $7 \mathrm{am}$ ) the price for electricity is only 7.5 cents per $\mathrm{kWh}$, which increases to 13.5 cents per $\mathrm{kWh}$ from $11 \mathrm{am}$ to $5 \mathrm{pm}$ when there is the most demand (OEB, 2014). While literature 
suggests TOU pricing be mandatory, most of the current programs are voluntary. In Ontario, for example, TOU pricing is mandated only to regulated price plan (RPP) customers that have smart meters installed, and includes small volume consumers, such as households and small businesses (ECO, 2014). The results from the 2014 Annual Energy Conservation Progress Report show that TOU pricing has led to an estimated on-peak electricity reduction of between $2.6 \%$ to $5.7 \%$ during the summer months. More savings could be observed it the price ratio between off-peak and on-peak pricing is increased (ECO, 2014).

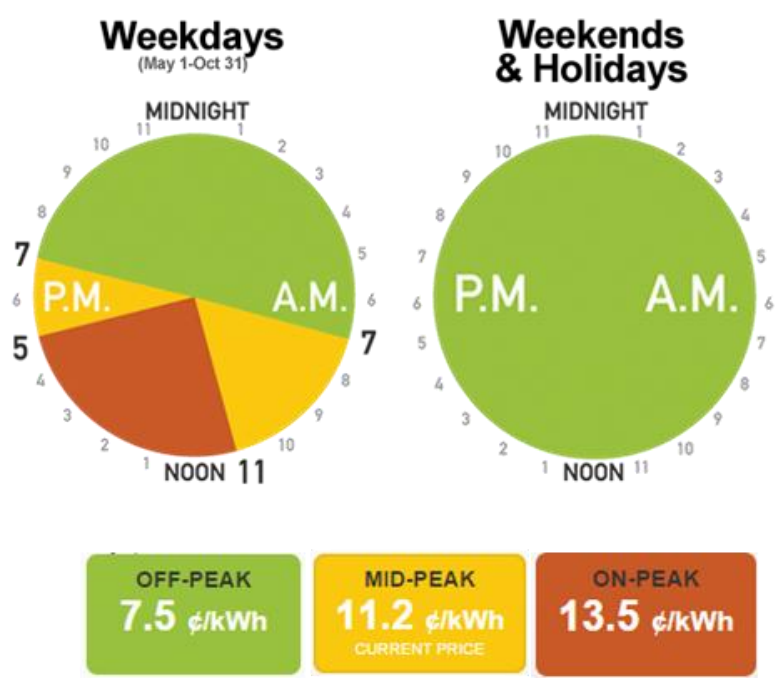

Figure 2.4. Ontario time-of-use electricity chart indicating the varying electricity prices charged depending on the time of use. During on-peak hours the price is almost double the price during off-peak hours. (OEB, 2014)

Chao (2010) provides a discussion about price-responsive management and the asymmetrical distribution of the social costs and benefits between off-peak and on-peak hours. As described in this paper, during on-peak hours both the consumer and producer incur net losses, while during off-peak hours both consumer and producer incur net benefits (Chao, 2010). Time varying rates were introduced to decrease consumption during peak hours and to better represent the marginal cost of electricity, which fluctuates depending on demand during the day, 
and the cost associated with possible power outages (Baladi, et al., 1998; Cochell, Schwarz, \& Taylor, 2012).

Other studies have shown that time varying rates are an improvement over flat rates and can be beneficial to both the producer and the consumer. Specifically, studies have revealed that households significantly altered their usage pattern under the TOU tariff (Faruqui \& Sergici, 2010) and that a proper adaptation of this pricing scheme would be beneficial to both the producer and the consumer; the producer would increase profit, while the consumer would save electricity cost (Yang, et al., 2013). However, the effects of a TOU tariff may depend on region, so it is necessary to consider total energy use and pattern in order to adequately assess the impact of TOU rates and select an adequate pricing scheme (Cochell, et al., 2012). Furthermore, highend and low-end consumers behave differently in the face of time varying electricity pricing with high-end consumer being more likely to decrease consumption than low-end consumers (Herter, 2007).

Although the benefits of time based pricing are abundant, implementation of such a tariff faces many barriers, such as the cost of purchasing and installing smart meters and the change of the billing system (Borenstein, 2013). Moreover, time-based pricing can increase the electricity bill of low-income households that are already struggling financially and do not have the ability to avoid paying high peak electricity rates (Alexander, 2010). As described in Borenstein (2013) this can be addressed by introducing a voluntary dynamic pricing tariff for well-informed customers. As shown by Baladi, et al. (1998) both households that volunteered and were mandated to participate in time-based pricing behaved similarly and altered their usage pattern. This suggests that an opt-in (volunteer) program would be quite beneficial, as it would provide the same results but decrease resistance of the participants in this pricing scheme. 
Table 2.2. Summary of key papers that consider the influence of socio-demographic variables in energy consumption and conservation. Continued in page 19.

\begin{tabular}{|c|c|c|c|}
\hline & Factor & Authors (year) & Summary of Key Results \\
\hline \multirow{19}{*}{ 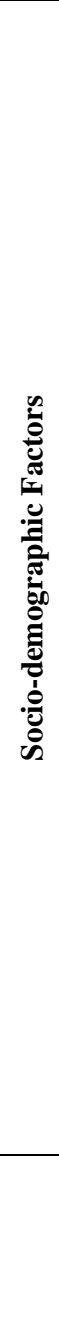 } & \multirow{5}{*}{ Age } & Nair, Gustavsson, \& Mahapatra, (2010) & - $\quad$ Sweden. Younger respondents are more likely to adopt an investment measure than older homeowners \\
\hline & & Poortinga, Steg, Vlek, \& Wiersma (2003) & - The Netherlands. Older participants (65 years and older) are less likely to invest in energy efficient technology \\
\hline & & Barr et al. (2005) & $\begin{array}{l}\text { - United Kingdom. Higher age groups are more likely to be energy savers. Respondents with mean age of } 55 \text { years } \\
\text { to partake in energy efficiency measures and investments than younger groups }\end{array}$ \\
\hline & & Gatersleben, B., Steg, L., \& Vlek, C. (2002) & - The Netherlands. Age is not significantly related to household energy use \\
\hline & & Long, J. E. (1993) & - United States. Homeowners older than 65 years made significant energy efficient investments \\
\hline & \multirow{7}{*}{ Gender } & Kollmuss, \& Agyeman, (2002) & $\begin{array}{l}\text { - Women have less environmental knowledge than men but show more environmental concern and are more } \\
\text { willing to change }\end{array}$ \\
\hline & & Zelezny, Chua, and Aldrich, (2000) & - Women show more pro-environmental behaviour than men \\
\hline & & Nair, Gustavsson, \& Mahapatra, 2010 & - $\quad$ Sweden. Gender does not influence homeowners' preference towards an energy efficiency measure \\
\hline & & Clark, Kotchen, \& Moore (2003) & $\begin{array}{l}\text { - United States. Gender is insignificant when the effect of other variables (such as income, and household } \\
\text { characteristics) are accounted for. }\end{array}$ \\
\hline & & Sardianou, E. (2007) & - $\quad$ Greece. Gender is not found to be a good predictors of energy-conserving behaviour \\
\hline & & Poortinga, Steg, Vlek, \& Wiersma (2003) & - The Netherlands. No relationship is found between gender and energy saving activities \\
\hline & & Schahn \& Holzer, (1990) & - Germany. Men have higher knowledge of environmental issues than women \\
\hline & \multirow[t]{4}{*}{ Education } & Nair, Gustavsson, \& Mahapatra, (2010) & $\begin{array}{l}\text { - Sweden. Respondents with higher educated are more likely to adopt an investment measure than homeowners } \\
\text { with only a primary education } \\
\text { - Homeowners with only a primary education were more likely to undertake only non-investment measures than } \\
\text { investment measures compared to those with higher education. } \\
\text { - Homeowners with secondary education are more likely to adopt other high investment energy efficiency } \\
\text { measures compared to those with university education }\end{array}$ \\
\hline & & Kollmuss, \& Agyeman, (2002) & - $\quad$ Higher education is not related to increased pro-environmental behavior \\
\hline & & $\begin{array}{l}\text { Poortinga, Steg, \& Vlek, (2004); } \\
\text { Poortinga, Steg, Vlek, Wiersma (2003) }\end{array}$ & $\begin{array}{l}\text { - } \quad \text { United Kingdom. Higher education is related to lower home energy use } \\
\text { Participants with lower education are more likely to partake in non-investment measures compared to participants } \\
\text { with higher education }\end{array}$ \\
\hline & & Sardianou, E. (2007) & - $\quad$ Education level of the consumers is not found to be a good predictors of energy-conserving behaviour \\
\hline & $\begin{array}{l}\text { Employment of } \\
\text { Occupants }\end{array}$ & Powers, Swan, \& Lee (1992) & - Full-time employment is related to household energy conserving investments. \\
\hline & $\begin{array}{l}\text { Household Income } \\
\text { and Size }\end{array}$ & Nair, Gustavsson, \& Mahapatra, 2010 & $\begin{array}{l}\text { - Sweden. The proportion of homeowners who adopted building envelope measures increases as annual household } \\
\text { income increases. }\end{array}$ \\
\hline & & $\begin{array}{l}\text { Poortinga, Steg, Vlek, Wiersma (2003); } \\
\text { Poortinga, Steg, \& Vlek, (2004) } \\
\text { Gatersleben, Steg, \& Vlek, (2002) }\end{array}$ & $\begin{array}{l}\text { - } \quad \text { The Netherlands. Investments are most acceptable for respondents with a high income. } \\
\text { - } \quad \text { Energy saving measures aimed at reducing direct energy are the least acceptable for high incomes } \\
\text { - } \quad \text { Energy saving measures are a migher energy use } \\
\text { with an average or high level of education }\end{array}$ \\
\hline
\end{tabular}


Table 2.2. Summary of key papers that consider the influence of socio-demographic variables in energy consumption and conservation. Continued from page 18 .

\begin{tabular}{|c|c|c|c|}
\hline & Factor & Authors (year) & Summary of Key Results \\
\hline \multirow{5}{*}{ 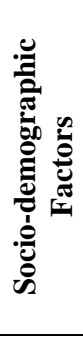 } & \multirow{3}{*}{$\begin{array}{l}\text { Household Income } \\
\text { and Size }\end{array}$} & Cayla, Maizi, \& Marchand (2011) & $\begin{array}{l}\text { - } \quad \text { France. Household with lower income are not likely to invest in energy efficient equipment } \\
\text { - } \quad \text { High income household are also not likely to invest in energy saving equipment }\end{array}$ \\
\hline & & Abrahamse \& Steg (2009) & - $\quad$ The Netherlands. Households with higher incomes tend to use more energy. \\
\hline & & O’Neill \& Chen (2002) & $\begin{array}{l}\text { - United States. Larger households have a higher total energy consumption } \\
\text { - Per capita consumption is lower in larger households }\end{array}$ \\
\hline & \multirow[b]{2}{*}{ Marital Status } & Sardianou, E. (2007) & - Marital status of the consumers is not found to be a good predictor of energy-conserving behaviour \\
\hline & & Poortinga, Steg, Vlek, \& Wiersma (2003) & $\begin{array}{l}\text { - The Netherlands. Couples and families are more likely to partake in technical improvements (investments) than } \\
\text { singles }\end{array}$ \\
\hline \multirow{8}{*}{ 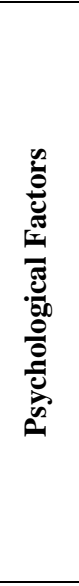 } & \multirow{8}{*}{$\begin{array}{l}\text { Environmental } \\
\text { Knowledge, } \\
\text { Values and Beliefs }\end{array}$} & Abrahamse \& Steg (2009) & - $\quad$ Psychological variables are not influential in energy use, but influential in household energy savings \\
\hline & & OECD (2008b) & - $\quad$ The association between psychological and attitudinal factors and energy demand is not very strong \\
\hline & & Mostafa (2007) & - $\quad$ Egypt. Environmental knowledge is positively correlated with green purchasing behavior \\
\hline & & $\begin{array}{l}\text { Kim \& Choi (2005) } \\
\text { Kalafatis, Pollard, East \& Tsogas, (1999) }\end{array}$ & - United States. Environmental concern is linked to likelihood of purchasing environmentally friendly products. \\
\hline & & Rowlands, Scott \& Parker (2003) & $\begin{array}{l}\text { - Canada. Peoples' willingness to pay higher premiums for green electricity is related to their belief that energy } \\
\text { sources have consequences on the environment }\end{array}$ \\
\hline & & Gatersleben, Steg \& Vlek, 2002 & $\begin{array}{l}\text { - The Netherlands. Environmental concern is not a significant factor that influences energy consumption or that } \\
\text { leads to environmentally friendly behaviour }\end{array}$ \\
\hline & & $\begin{array}{l}\text { Bang, Ellinger, Hadjimarcou, \& Traichal } \\
(2000)\end{array}$ & $\begin{array}{l}\text { - } \quad \text { Environmental concern is linked to willingness to pay for renewable energy. } \\
\text { - } \quad \text { Consumers report high levels of concern but low levels of knowledge about renewable energy } \\
\text { - } \quad \text { Renewable energy knowledge increases consumers' likelihood of paying more for sustainable energy sources }\end{array}$ \\
\hline & & Axelrod \& Lehman (1993) & $\begin{array}{l}\text { - Canada. Environmentally-concerned behavior does not appear to be motivated solely by the ideal of helping save } \\
\text { the environment. Rather, both tangible and social outcome desires seem to impact upon one's motivation to act as } \\
\text { well. }\end{array}$ \\
\hline \multirow{4}{*}{ 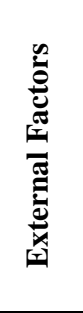 } & \multirow{3}{*}{ Electricity Prices } & Berkhout et al. (2004) & - $\quad$ The Netherlands. Household demand for electricity can be better modified through changes in prices \\
\hline & & John $(2000)$ & $\begin{array}{l}\text { - India, Indonesia, the Philippines, Thailand. Energy, income and prices are mutually causal in Thailand and the } \\
\text { Philippines } \\
\text { - Energy and income are neutral with respect to each other in Indonesia and India }\end{array}$ \\
\hline & & Nesbakken, R. (1999) & - Norway. High-income households are more sensitive to energy price changes than low-income households \\
\hline & $\begin{array}{l}\text { Social and } \\
\text { Cultural Factors }\end{array}$ & Axelrod, \& Lehman (1993) & $\begin{array}{l}\text { - Canada. Environmentally-concerned behavior does not appear to be motivated only by the idea of helping save } \\
\text { the environment. Social outcome desires have an impact on one's motivation to act. }\end{array}$ \\
\hline
\end{tabular}




\section{CHAPTER 3: EMPIRICAL FRAMEWORK}

In this Chapter the approach to study households' energy usage behaviour and the decision to adopt energy conserving measures and investments is described. This study employs a model that allows for the analysis of the impact on energy saving measures and investments while accounting for the interdependence among the various energy saving activities. Ten dependent variables are used in this analysis: (1) five indicators for the different energy saving measures; (2) four indicators for the different energy saving investments; (3) and one indicator for renewable energy technology investment. This study evaluates the relation between different factors and the likelihood of adopting energy saving measure and investments. Specifically, it looks at whether there is a relationship between implementation of time-of-use (TOU) electricity pricing and the likelihood of adopting energy saving activities, while controlling for the effect of background variables (socio-demographic variables). Considering the binary nature of the dependent variables, the model used allows for the estimation of the probability of participating in each of the energy saving activities using the multivariate probit model.

\subsection{Data and Variables}

The data set used in this project was gathered by Lightspeed Online Research Inc. for the OECD in February 2008 through an international web-based panel of 10,251 respondents from ten countries (Australia, Canada, Czech Republic, France, Italy, Korea, Mexico, Netherlands, Norway, and Sweden) (OECD, 2008a). All ten countries in the survey are OECD member countries and included countries of different development and income level. Lightspeed Online Research Inc. recruited respondents through websites in each country and used niche websites to select participants from different demographic groups. Selection of the participants was performed using an algorithm conducted by MARSC software to ensure the sample was 
stratified by income, age, gender, and region in each of the ten countries (OECD, 2008a). The socio-demographic data collected were compared with official sources for each country to ensure that sample was representative and unbiased. In addition, participants that did not respond to the survey satisfactory were removed from the data set, and the sample was stratified by income, age, gender and region in each of the ten countries (OECD, 2008a). The explanatory variables presented in Table 3.3 include information on individual, household and attitudinal characteristics, energy efficient activities and policy instrument.

All variables representing individual characteristics, household characteristics, measures, investments, and policy instruments (presented in Table 3.3) are coded into binary variables. For example for variable (Canada), responses that selected being from Canada were given a value 1 and responses that selected any other country were given a value of 0 . Measures and motivator variables take 4 possible values: never, occasionally, often, and always for measures and not at all important, not important, fairly important, and very important for motivators. For "measures" variables, never and occasionally were considered as a "negative" response and given the value of 0, while often and always were considered as a "positive" answer and given the value of 1. The same procedure was performed for "motivator" variables. Moreover, during this analysis the following were done:

1) Observations where participants selected "don't know" or "blank" responses for income, education, employment, occupation, and residence type were removed from the data set. A summary of the observations removed is presented in Table 3.1.

2) For outcome variables (measure and investments), motivators, and pricing policy (Policy_timeofuse), responses marked as “don’t know" or "blank" were assumed to be a "negative" response, allowing for a larger data set. The total number of surveys used in this 
analysis after the removal of "blank" and "don't know" observations is tabulated in Table 3.2.

3) Additionally, the analysis was performed without considering the assumption in point 2 and all observations with "blank" and "don't know" responses were removed from the data set. This alternative analysis is presented in Appendix D.

Table 3.1 Observations removed for the five different variables.

\begin{tabular}{|l|c|c|c|}
\hline \multirow{2}{*}{ Variable } & \multicolumn{3}{|c|}{ Observations Removed } \\
\cline { 2 - 4 } & $\begin{array}{c}\text { Don't know/ } \\
\text { Other answer }\end{array}$ & $\begin{array}{c}\text { Prefer not to say/ } \\
\text { Blank answer }\end{array}$ & $\begin{array}{c}\text { Total number of } \\
\text { responses removed }\end{array}$ \\
\hline Income & 236 & 482 & 718 \\
\hline Education & 0 & 99 & 99 \\
\hline Employment & 0 & 419 & 419 \\
\hline Occupation & 941 & 1807 & 2748 \\
\hline Residence type & 202 & 0 & 202 \\
\hline \multicolumn{4}{|c|}{ Total observations removed } \\
\hline
\end{tabular}

Table 3.2. Number of surveys used in this analysis after the removal of "blank" and "don't know" observations.

\begin{tabular}{|l|c|c|}
\hline Country & $\begin{array}{c}\text { Total surveys } \\
\text { administered }\end{array}$ & $\begin{array}{l}\text { Number of surveys } \\
\text { used in this analysis }\end{array}$ \\
\hline AUS & 1,006 & 511 \\
\hline CAN & 1,003 & 556 \\
\hline CZR & 701 & 442 \\
\hline FRA & 1,075 & 726 \\
\hline ITA & 1,417 & 940 \\
\hline KOR & 1,001 & 530 \\
\hline MEX & 1,009 & 680 \\
\hline NLD & 1,015 & 411 \\
\hline NOR & 1,019 & 705 \\
\hline SWE & 1,006 & 555 \\
\hline & 10,252 & 6,056 \\
\hline
\end{tabular}


Table 3.3. Definition and description of explanatory variables.

\begin{tabular}{|c|c|c|c|c|c|}
\hline & Variable & Description & & Variable & Description \\
\hline \multirow{35}{*}{ 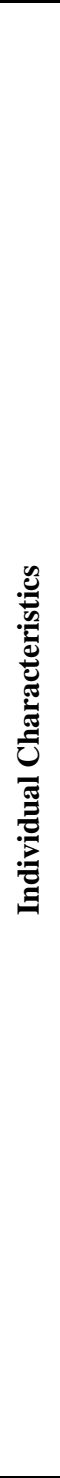 } & AUS & Australia indicator & \multirow{4}{*}{ 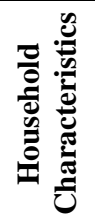 } & type_house & House indicator \\
\hline & CAN & Canada indicator & & type_apartment & Apartment indicator \\
\hline & CZR & Czech Republic indicator & & area_rural & Rural location and isolated location indicator \\
\hline & FRA & France indicator & & area_urban & Urban and suburban location indicator \\
\hline & ITA & Italy indicator & \multirow{6}{*}{ 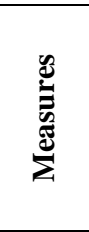 } & Measure_lights & Turn-off lights when leaving a room indicator \\
\hline & KOR & Korea indicator & & Measure_heating & Cut down heating/AC indicator \\
\hline & MEX & Mexico indicator & & & Waiting for full load before using washing machine or dishwasher \\
\hline & NLD & Netherlands indicator & & Measure_load & indicator \\
\hline & NOR & Norway indicator & & Measure_applian & Turn-off appliances when not in use indicator \\
\hline & SWE & Sweden indicator & & Measure_standby & Switch off standby mode of appliances indicator \\
\hline & gender_male & Male indicator & \multirow{6}{*}{ 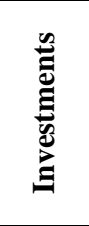 } & Efficient_appliances & Installed energy efficient appliances in the past 10 years \\
\hline & Married & Married/living as a couple indicator & & Efficient_bulbs & Installed low-energy light bulb in the past 10 years \\
\hline & \multirow{2}{*}{ Income } & Has annual combined income higher & & Efficient_insulation & Installed thermal insulation in the past 10 years \\
\hline & & than $\$ 54,700$ & & Efficient_heating & Installed efficient heating boiler in the past 10 years \\
\hline & age_class_1 & Age 18 to 24 indicator & & Renewable eneroy & Installed renewable energy equipment (solar panel, wind turbines) in the \\
\hline & age_class_2 & Age 25 to 34 indicator & & & past 10 years \\
\hline & age_class_3 & Age 35 to 44 indicator & \multirow{6}{*}{ 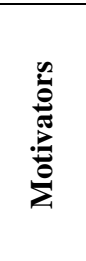 } & Mtv_information & Information on energy conservation as motivator \\
\hline & age_class_4 & Age 45 to 54 indicator & & Mtv_price & Higher energy prices as motivator \\
\hline & age_class_5 & Older than 54 years old indicator & & Mtv_environment & Belief that environmental benefits are significant as motivator \\
\hline & edu_1 & No high school indicator & & Mtv_energyefficient & Availability of energy efficient products as motivator \\
\hline & edu_2 & High school indicator & & Mtv_labels & Easier identification of energy efficient labels as motivator \\
\hline & edu_3 & $\begin{array}{l}\text { Some post-secondary education } \\
\text { indicator }\end{array}$ & & Mtv_cheapequipment & Less expensive energy efficient equipment as motivator \\
\hline & edu_4 & Bachelor degree indicator & \multirow{12}{*}{ 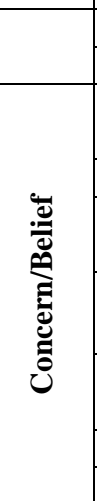 } & policy_timeofuse & Time of use electricity billing indicator \\
\hline & edu_5 & Post_graduate degree indicator & & BUYRNWL & Does your household take special measures to buy renewable energy? \\
\hline & empl_fulltime & Full-time employment indicator & & \multirow{2}{*}{ BETTRENV_LKRT } & \multirow{2}{*}{$\begin{array}{l}\text { Belief that each individual/household can contribute to a better } \\
\text { environment }\end{array}$} \\
\hline & empl_leave & Employed but on leave indicator & & & \\
\hline & empl_retired & Retired indicator & & OVRSTATE_LKRT & Belief that environmental impacts are frequently overstated \\
\hline & empl_homemaker & Homemaker indicator & & \multirow{2}{*}{ FUTRGNRS_LKRT } & \multirow{2}{*}{$\begin{array}{l}\text { Belief that environmental issues should be dealt with primarily by future } \\
\text { generations }\end{array}$} \\
\hline & empl_parttime & Part-time employment indicator & & & \\
\hline & empl_unemployed & $\begin{array}{l}\text { Student, volunteer, and unemployed } \\
\text { indicator }\end{array}$ & & TECHPROG_LKRT & $\begin{array}{l}\text { Belief that environmental issues will be resolved primarily through } \\
\text { technological progress }\end{array}$ \\
\hline & occup_professional & Professional occupation indicator & & \multirow{2}{*}{ NOTCOSTS_LKRT } & \multirow{2}{*}{$\begin{array}{l}\text { Belief that environmental policies introduced by the government should } \\
\text { not cost me extra money }\end{array}$} \\
\hline & occup_executives & Executives occupation indicator & & & \\
\hline & occup_selfemployed & Self-employed occupation indicator & & CLCH_LKRT & Concern over climate change (global warming) \\
\hline & occup_salaried & Salaried occupation indicator & & NRSC_LKRT & Concern over natural resource depletion (forest, water, energy) \\
\hline & occup_worker & Manual worker occupation indicator & & & \\
\hline
\end{tabular}


Individual characteristics presented are: gender (Gender_Male), marital status (Status_married), age (Age_class), education (Edu_class), employment status (Empl) and occupation (Occup). Figure 3.1 represents the number of participants in each group for each of the individual characteristic variables. Household characteristics used are: residence type (Restype) and the type of area where the residence is located (Area). Of the 6,056 participants, 3,543 live in a house and 2,513 in an apartment; 1,424 in a rural areas and 4,632 in an urban areas.

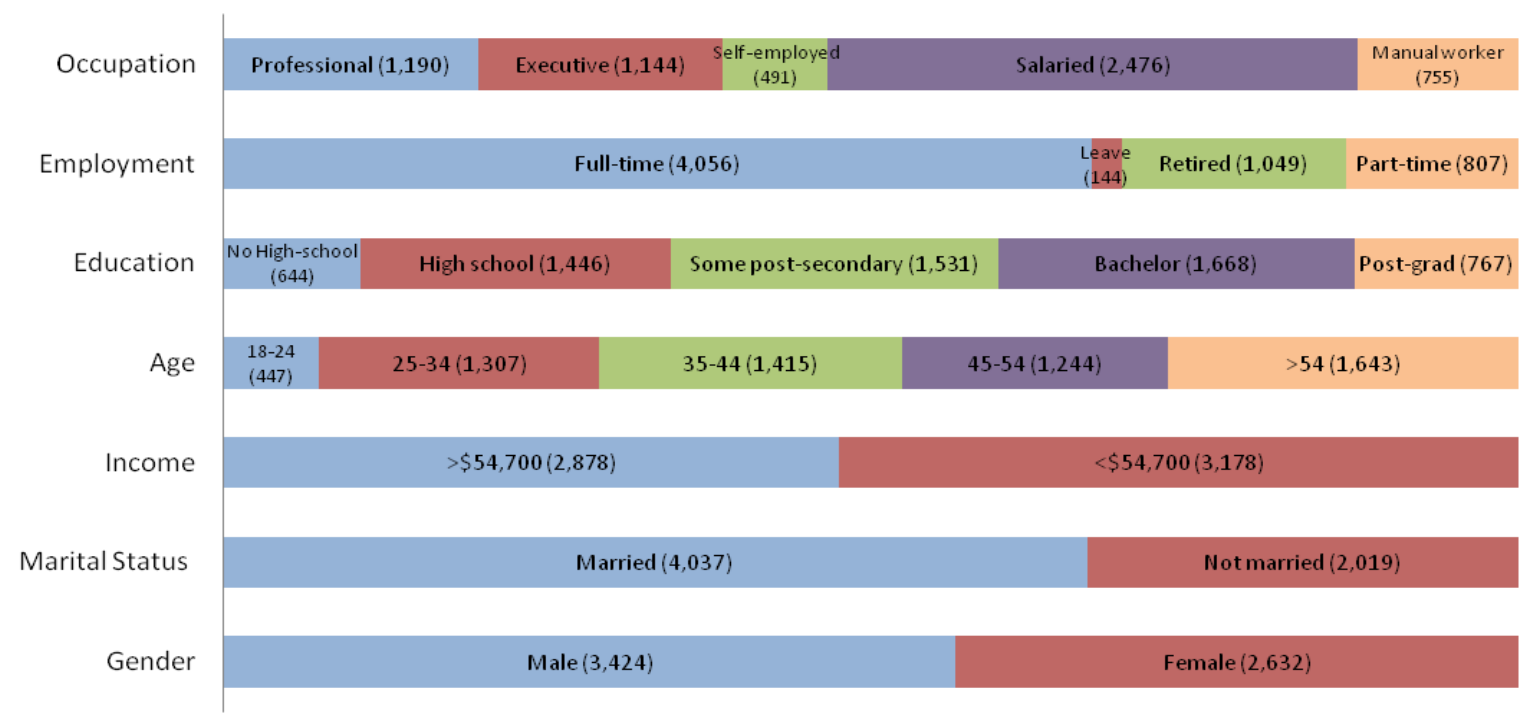

Figure 3.1. Number of respondents for each group of individual characteristic variables

Attitudinal characteristics are categorized into two groups: those that include simple behavioural measures (Measures) and those that require investment such as the implementation of energy efficient appliances or use of renewable energy (Investments). Specifically, the measures evaluated in this analysis are the likelihood of: (1) turning-off lights when not in use (Measure_lights); (2) cutting-down heating/AC temperature (Measure_heating); (3) waiting for full load before using washing machine or dishwasher (Measure_load); (4) turning-off appliances when not in use (Measure_applian); (5) switching appliances to standby mode 
(Measure_standby). Household investments evaluated in this project are: (1) having installed energy efficient appliances in the past 10 years (Efficient_appliances); (2) having installed lowenergy light bulb in the past 10 years (Efficient_bulbs); (3) having installed thermal insulation in the past 10 years (Efficient_insulation); (4) having installed efficient heating boiler in the past 10 years (Efficient_heating); (5) having installed renewable energy equipment (solar panel, wind turbines) in the past 10 years (Renewable_energy). The following figures provide some graphical representation of the participation in energy saving actives per each of the ten countries in this study. As seen in Figure 3.2 and 3.3, the participation in measures is much higher than that of investments; however, there are differences between the five different measures, between the five different investments, and between countries.

Another important factor to consider is what motivates people to partake in these energy efficient measures and investments, and the effect of time-of-use electricity rates (Policy_timeofuse). Of the 6,056 participants in this analysis, 2,435 reported having electricity pricing that depends on the time of day, while 3,621 reported they didn't have or they didn't know if they had this pricing scheme. The motivators considered are: (1) information on energy conservation (Mtv_information); (2) higher energy prices (Mtv_price); (3) belief that environmental benefits are significant (Mtv_environment); (4) availability of energy efficient products (Mtv_energyefficient); (5) easier identification of energy efficient labels (Mtv_labels); (6) less expensive energy efficient equipment (Mtv_cheapequipment). Lastly, the relation between personal belief on environmental concern on the likelihood of a household purchasing renewable energy from the supplier (BUYRNWL) will be evaluated. The factors considered are: (1) belief that each individual/household can contribute to a better environment (BETTRENV_LKRT); (2) belief that environmental impacts are frequently overstated 
(OVRSTATE_LKRT); (3) belief that environmental issues should be dealt with primarily by future generations (FUTRGNRS_LKRT); (4) belief that environmental issues will be resolved primarily through technological progress (TECHPROG_LKRT); (5) belief that environmental policies introduced by the government to address environmental issues should not cost me extra money (NOTCOSTS_LKRT); (6) concern over climate change (global warming) (CLCH_LKRT); (7) concern over natural resource depletion (forest, water, energy) (NRSC_LKRT).

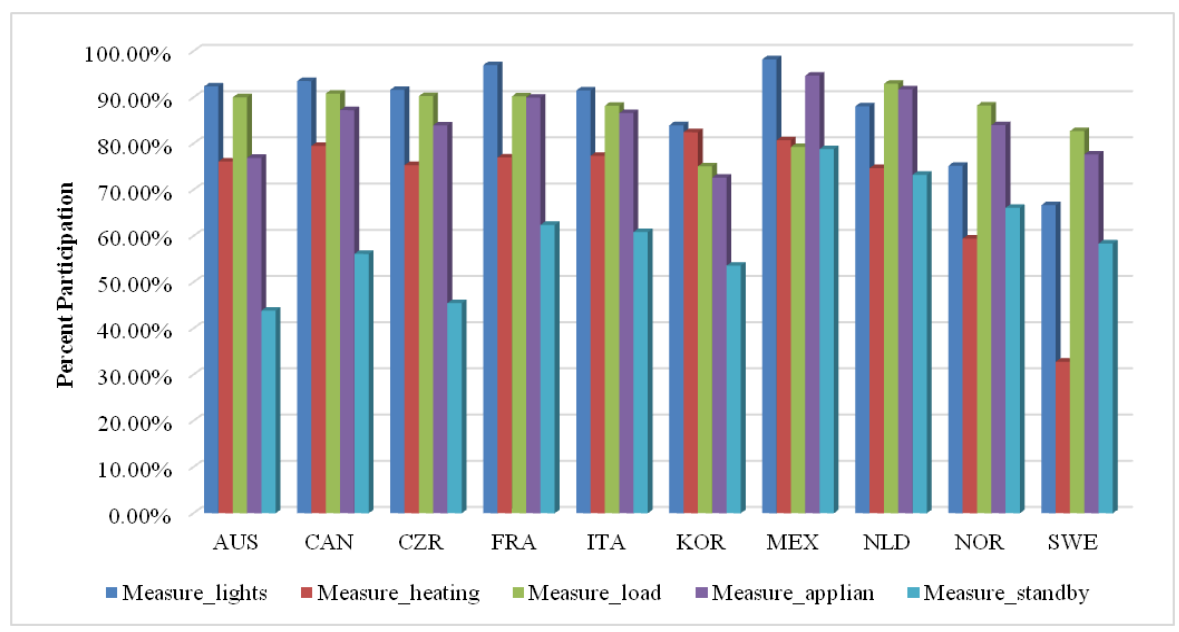

Figure 3.2. Percent participation of each country in energy efficient measures

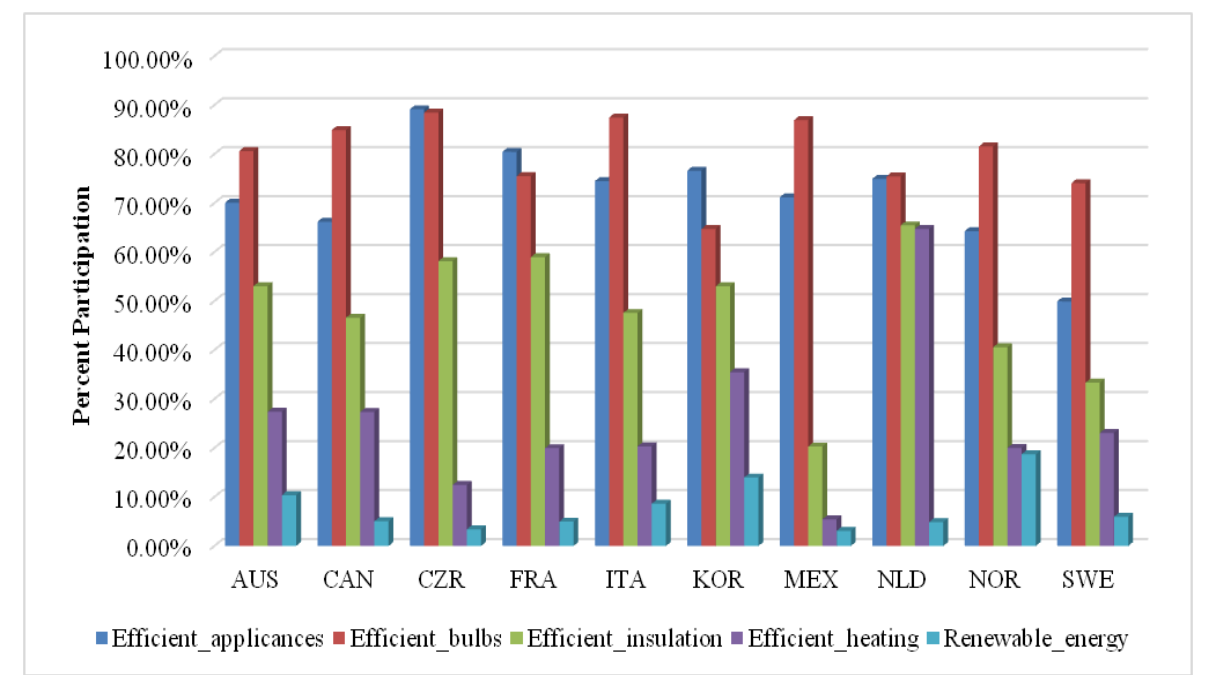

Figure 3.3. Percent participation of each country in energy efficient investments 
Moreover summary statistics of variables for the entire sample set used in this study are provided in Table 3.4. In general, households partake in energy efficient measures more than energy efficient investments. Installation of efficient heating boiler and renewable energy equipment are the least common investments, while all motivators are believed to be important by most of the participants. Less than half of the participants have a household income higher than $\$ 54,700$ a year and a higher number of participants have salaried occupations, full-time employment, and live in urban areas. The summary statistics indicate that the least common age group is between 18 and 24 years old, while the education is generally equally distributed, with having no high school education and having a post-graduate degree being the least common. The mean for time varying electricity pricing (policy_timeofuse) is 0.4021 demonstrating that less than $50 \%$ of the participants of the survey have this pricing scheme.

\subsection{Methodology}

\subsubsection{Probit Model}

Based on the analysis by Ferrara and Missios (2012) on the waste portion of the survey used for this paper, the probit model is selected to assess the impact of different factors on the likelihood of households employing energy efficiency technologies/appliances and renewable energy. Specifically, the decisions whether to adopt energy conservation practices and whether to purchase energy efficient and renewable energy technology is studied through univariate and multivariate probit. The description of the binary model presented below is based on the paper by Cappellari and Jenkins (2003). The probit model (or probit regression) is used to model binary outcome variables - outcomes that can take only two values, for example yes or no, or adopt or don't adopt. The probability of the response variable $\mathrm{Y}$ occurring is described in Equation 1. In 
this model the vector of regressors (independent variables) $\mathrm{X}$ will influence the outcome of the response variable $\mathrm{Y}$.

$$
\operatorname{Pr}(Y=1 \mid X)=\phi\left(X \beta^{\prime}\right) \quad \text { Equation } 1
$$

where Pr denotes the probability, $\phi$ is the Cumulative Distribution Factor (CDF) of the normal distribution, and $\beta$ are parameters estimated by maximum likelihood estimation (MLE). The probit model can also be written as a latent variable model as described in Equation 2. If $M$ binary choices (measures and investments) that are mutually dependent (i.e. occurrence of one variable affects the probability of the other variable) are present, the $M$-equation multivariate probit can be written as:

$$
y_{i m}^{*}=\beta_{m}^{\prime} X_{i m}+\varepsilon_{i m},
$$

Equation 2

where $\varepsilon_{i m}$ is the standard error and $m=1, \ldots, M$. The idea of the latent variable model is based on the effect of a set of observable or measurable variables (manifest variables) on the latent variable $y^{*}$, and the resulting measurement equation links the observed $y$ with the latent $y^{*}$ as described in Equation 3:

$$
y_{\text {im }}=\left\{\begin{array}{l}
1 \text { if } y_{\text {im }}^{*}>0 \\
0 \text { otherwise }
\end{array},\right.
$$

Equation 3

where $y_{\text {im }}$ represents outcomes for $M$ different choices.

The output of the probit analysis provides coefficients, their standard errors, the z-statistic, associated p-values, and the $95 \%$ confidence interval of the coefficients. The probit regression coefficients give the change in the z-score for one unit change in the independent variable. 
Table 3.4. Summary statistics for all variables.

\begin{tabular}{|c|c|c|c|c|c|c|c|c|}
\hline Variable & Mean & Std. Dev. & Variable & Mean & Std. Dev. & Variable & Mean & Std. Dev. \\
\hline AUS & 0.0844 & 0.2780 & edu_4 & 0.2754 & 0.4468 & Measure_standby & 0.6065 & 0.4886 \\
\hline $\mathrm{CAN}$ & 0.0918 & 0.2888 & edu_5 & 0.1267 & 0.3326 & Efficient_appliances & 0.7153 & 0.4513 \\
\hline CZR & 0.0730 & 0.2601 & empl_fulltime & 0.6697 & 0.4703 & Efficient_bulbs & 0.8050 & 0.3962 \\
\hline FRA & 0.1199 & 0.3248 & empl_leave & 0.1333 & 0.3399 & Efficient_insulation & 0.4658 & 0.4989 \\
\hline ITA & 0.1552 & 0.3621 & empl_retired & 0.1732 & 0.3785 & Efficient_heating & 0.2383 & 0.4261 \\
\hline KOR & 0.0875 & 0.2826 & empl_homemaker & 0.0000 & 0.0000 & Renewable_energy & 0.0814 & 0.2735 \\
\hline MEX & 0.1123 & 0.3157 & empl_parttime & 0.0238 & 0.1524 & Mtv_information & 0.8035 & 0.3974 \\
\hline NLD & 0.0679 & 0.2515 & empl_unemployed & 0.0000 & 0.0000 & Mtv_price & 0.6762 & 0.4680 \\
\hline NOR & 0.1164 & 0.3207 & occup_professional & 0.1965 & 0.3974 & Mtv_environment & 0.8317 & 0.3741 \\
\hline SWE & 0.0916 & 0.2885 & occup_executives & 0.1889 & 0.3915 & Mtv_energyefficient & 0.8998 & 0.3003 \\
\hline gender_male & 0.5654 & 0.4957 & occup_selfemployed & 0.0811 & 0.2730 & Mtv_labels & 0.8266 & 0.3786 \\
\hline married & 0.6666 & 0.4715 & occup_salaried & 0.4089 & 0.4917 & Mtv_cheapequipment & 0.9275 & 0.2593 \\
\hline income & 0.4752 & 0.4994 & occup_worker & 0.1247 & 0.3304 & policy_timeofuse & 0.4021 & 0.4904 \\
\hline age_class_1 & 0.0738 & 0.2615 & type_house & 0.5850 & 0.4928 & BUYRNWL & 0.1328 & 0.3393 \\
\hline age_class_2 & 0.2158 & 0.4114 & type_apartment & 0.4150 & 0.4928 & BETTRENV_LKRT & 0.9569 & 0.2031 \\
\hline age_class_3 & 0.2337 & 0.4232 & area_rural & 0.2351 & 0.4241 & OVRSTATE_LKRT & 0.3293 & 0.4700 \\
\hline age_class_4 & 0.2054 & 0.4040 & area_urban & 0.7649 & 0.4241 & FUTRGNRS_LKRT & 0.2781 & 0.4481 \\
\hline age_class_5 & 0.2713 & 0.4447 & Measure_lights & 0.8811 & 0.3237 & TECHPROG_LKRT & 0.5418 & 0.4983 \\
\hline edu_1 & 0.1063 & 0.3083 & Measure_heating & 0.7173 & 0.4503 & NOTCOSTS_LKRT & 0.6255 & 0.4840 \\
\hline edu_2 & 0.2388 & 0.4264 & Measure_load & 0.8666 & 0.3401 & CLCH_LKRT & 0.7606 & 0.4268 \\
\hline edu_3 & 0.2528 & 0.4347 & Measure_applian & 0.8496 & 0.3575 & NRSC_LKRT & 0.8137 & 0.3894 \\
\hline
\end{tabular}


3.2.2. Multivariate and Univariate Probit Analysis of the Effects of Individual Characteristics, Household Characteristics and Policy Variable on Measures and Investments

In this analysis $10(M=10)$ equations (measures and investments) are considered (tabulated in Table 3.1 and described in Section 3.1). The univariate probit allows for the study of the effect that the individual, household and policy variables have on outcomes variables. Specifically, it looks at the effect that an independent variable has on the outcome (measure and investment) assuming that the outcomes themselves (decisions) are independent of each other. On the other hand, the multivariate probit model allows for the study of the probability of engaging in a specific energy conservation activity being related to the decision of engaging in a different energy conservation activity, while controlling for background variables. This model assumes that one decision can depend on other decisions, but it may not. Figure 3.4 is a simple representation of the relationships evaluated in this section. The literature described in Section 2.3 indicates that background variables such as gender, marital status, and income impact the likelihood of a person adopting energy saving actions (OECD, 2011); as such, the background variables in Figure 3.4 are expected to have a direct impact or effect on the outcomes.

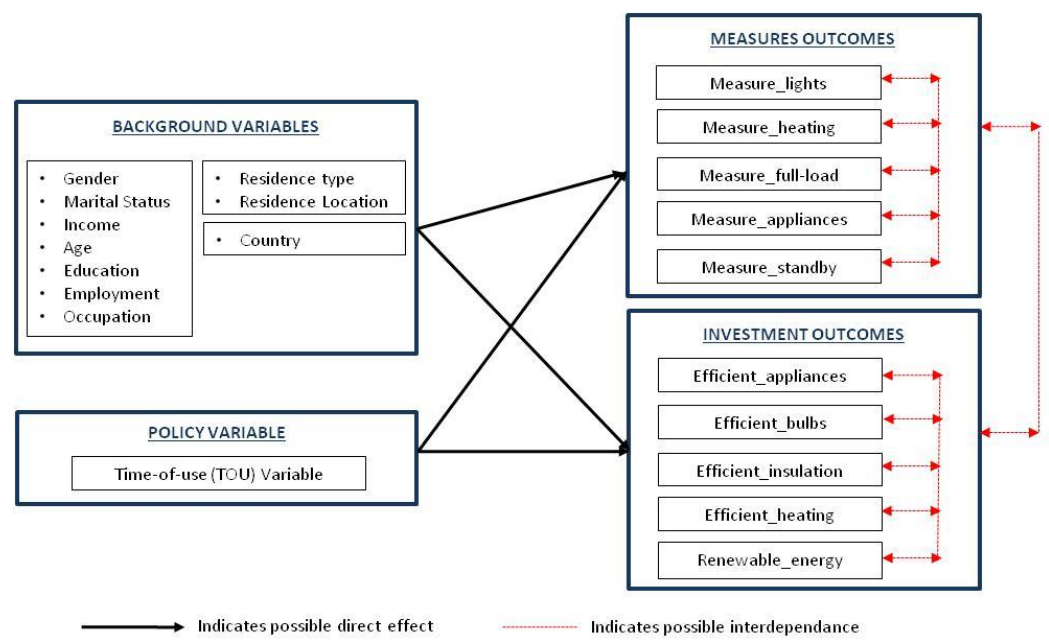

Figure 3.4: Model used in the study of the effect of policy and background variables on energy saving measures and investments through the multivariate probit regression. 
As shown in Section 2.3.3.1, TOU pricing has been suggested to have an impact on the energy saving actions, and it is expected that this variable directly impacts the outcomes evaluated in this study. Moreover, it can be assumed that participants that partake in one energy saving outcome are more likely to partake in other energy saving outcomes. This model allows for the decision of a particular energy conservation activity to be related with the decision of a different energy conservation activity being implemented, while controlling for the background variables. For each background variable a reference group is selected creating a baseline. For example, Korea is selected as the country in the baseline and the effect of substituting each of the other 9 countries for Korea on the outcome variables is evaluated while maintaining all the other background variables constant.

\subsubsection{Probit Analysis of the Effects of Environmental Concern on Renewable Energy Purchase}

In this multivariate probit analysis, the outcome (dependent) variables is the purchase of renewable energy and the predictor variables are environmental concern (tabulated in Tables 3.5 and 3.6). The predictor variables take the values "strongly disagree", "disagree", "agree" and "strongly agree". Since binary data are used in this analysis, strongly disagree and disagree were grouped together, and agree and strongly agree were grouped together as shown in Table 3.5. The same procedure is done for "not concerned", "fairly concerned", "concerned" and "very concerned" as shown in Table 3.6. The results of this analysis are presented in Section 4.2. As in the previous analysis, for continuous variables, a one unit increase in the independent variable, increases the z-score by the coefficient value. 
Table 3.5. Description of the independent variables used in the analysis of the relationship between purchase of renewable energy and environmental concern.

\begin{tabular}{|l|l|l|l|}
\hline \multicolumn{1}{|c|}{ Description } & Variable name & $\begin{array}{c}\text { Not Concerned, } \\
\text { Fairly Concerned, } \\
\text { and No Opinion (0) }\end{array}$ & $\begin{array}{c}\text { Concerned and } \\
\text { Very concerned } \\
\text { (1) }\end{array}$ \\
\hline $\begin{array}{l}\text { Climate change } \\
\text { (global warming) }\end{array}$ & CLCH_LKRT & & \\
\hline $\begin{array}{l}\text { Natural resource depletion } \\
\text { (forest, water, energy) }\end{array}$ & NRSC_LKRT & & \\
\hline
\end{tabular}

Table 3.6. Description of the independent variables used in the analysis of the relationship between purchase of renewable energy and environmental concern.

\begin{tabular}{|l|l|l|l|}
\hline \multicolumn{1}{|c|}{ Description } & Variable name & $\begin{array}{c}\text { Strongly Disagree, } \\
\text { Disagree, and No } \\
\text { Opinion (0) }\end{array}$ & $\begin{array}{c}\text { Agree and } \\
\text { Strongly } \\
\text { Agree (1) }\end{array}$ \\
\hline $\begin{array}{l}\text { Each individual/household can } \\
\text { contribute to a better environment }\end{array}$ & BETTRENV_LKRT & & \\
\hline $\begin{array}{l}\text { Environmental impacts are } \\
\text { frequently overstated }\end{array}$ & OVRSTATE_LKRT & & \\
\hline $\begin{array}{l}\text { Environmental issues should be } \\
\text { dealt with primarily by future } \\
\text { generations }\end{array}$ & FUTRGNRS_LKRT & & \\
\hline $\begin{array}{l}\text { Environmental issues will be } \\
\text { resolved primarily through } \\
\text { technological progress }\end{array}$ & TECHPROG_LKRT & & \\
\hline $\begin{array}{l}\text { Environmental policies } \\
\text { introduced by the government to } \\
\text { address environmental issues } \\
\text { should not cost me extra money }\end{array}$ & NOTCOSTS_LKRT & & \\
\hline
\end{tabular}

\subsubsection{Multivariate Probit Analysis of the Effects of Motivators on Measures and Investments}

A multivariate probit model was used to assess the relation between the independent variables (motivators) and outcome variables (energy saving measures and investments) of the participants (variables tabulated in Table 3.1). The results of this analysis are presented in Section 4.3. 


\subsubsection{Empirical Analysis of Motivators}

In this section, the participants were asked to rate factors that would encourage the household to reduce energy consumption (Motivators in Table 3.1). The participants had four options to choose from: "not at all important"; "not important"; "fairly important"; and "very important". In the analysis, "fairly important" and "very important" were grouped together and converted to a percentage of the total number of participants per country. For example:

- Total number of participants for Canada $=556$

- Number of participants that reported that having information on energy conservation (Mtv_information) is a fairly or very important motivator in reducing household energy consumption $=455$

- Percent of responses considering the motivator fairly or very important $=455 / 556 \times 100 \%=$ $81.83 \%$

So, $81.83 \%$ of Canadian responders claimed that having information on energy conservation is a good motivator in reducing household energy consumption. The summary of these calculations is presented in Table 4.5, and the analysis of these results is presented Section 4.4. 


\section{CHAPTER 4: RESULTS AND DISCUSSION}

\subsection{Multivariate and Univariate Probit Analysis of the Effects of Individual, Household and Policy Variable on Measures and Investments}

The results from the multivariate and univariate binary probit estimation are provided in Appendix B and Appendix C. Tables 4.1 and 4.2 shows the results with explanatory variables that are statistically significant in at least one of the equations (measures or investments) in which they are included. The variable for being employed but not currently working (Empl_leave) is excluded because it is statistically insignificant in all 10 equations and hence does not impact energy saving measures and investments. In addition, the variable for being a homemaker (Empl_homemaker) and being retired (Empl_retired) were removed due to colinearity of results. These variables are perfectly colinear with other independent variables in the data set and they do not impact the outcome of the analysis.

Before elaborating on the effects of individual and household characteristics, attitudinal factors, and policy variable on households' energy consumption, it should be noted that multivariate probit provides a good estimate for this model - there is evidence of dependence between the energy saving measures and energy saving investment activities considered in this paper. The hypothesis that the 45 off-diagonal coefficients of the variance-covariance matrix are equal to 0 is rejected, with chi2(45)=3455.87, at less than $1 \%$ (results found in Appendix B, Table B3). This explains the slight differences in the coefficients obtained from multivariate and univariate probit model; however, the effect of the variables on measures and investments are generally consistent, with the following discrepancies:

(a) Being married negatively impacts the likelihood of switching off appliances to standby mode when not in use (Measure_standby) when the multivariate probit model is used; however, a positive impact is observed when the univaraite probit model. Similar 
inconsistencies are observed for the effects of having no high school (edu_1) on the likelihood of installing thermal insulation (Efficient_insulation), having some postsecondary education (edu_3) on the likelihood of turning off lights when leaving the room (Measure_lights), and being a professional (occup_professionals) on the likelihood of cutting down on heating/AC (Measure_heating). However, all these coefficients are insignificant and do not pose a concern for this analysis.

(b) Another dissimilarity observed between the multivariate probit and univariate probit results is the significance of results in one of the models, and insignificance of results in the other.

- Using the multivariate probit model, it is observed that households in the Netherlands (NLD) are less likely than households in Korea to install energy efficient appliances (Efficient_applinaces). On the other hand, the result is insignificant when using the univariate probit model. This indicates that being from the Netherlands has an impact on the decision to invest in efficient appliances when controlling for the effect of background variables. The same is observed for the impact of having some post secondary education (edu_3) on waiting for a full load before using the washing machine (Measure_load) and having a bachelor degree (edu_4), being a professional (occup_professionals) and having a salaried employment (occup_salaried) on the likelihood of installing efficient light bulbs (Efficient_bulbs).

- Being married has a positive impact on the likelihood of installing thermal insulation (Efficient_insulation) when using the multivariate probit model, but no impact when using the univariate probit model. This is also observed for the impact of working part-time (empl_parttime), being an executive (occup_executive), and being self- 
employed (occup_selfemployed) on the likelihood of installing efficient light bulbs (Efficient_bulbs).

- Using the univariate probit model, it is observed that having a household income higher than $\$ 54,700$ (income) a year negatively impacts the likelihood of cutting down on heating/AC (Measure_heating). On the other hand, the results are insignificant using the multivariate probit model, indicating that when controlling for the effects of background variables, income does not have an impact on this energy efficient measure. Additionally, this is observed for the impact of being between ages 25 and 34 (age_class_2) on the likelihood of purchasing renewable energy (Renewable_energy) and for the impacts of being from an urban or suburban area (area_urban) on the likelihood of cutting down on heating/AC (Measure_heating) and turning of appliances when not in use (Measure_applian).

The following Sections describe the effects of individual, household and altitudinal factors on energy saving measures and investments considering only statistically significant results.

\subsubsection{Time of Use Policy (TOU)}

The effects of varying electricity pricing (Policy_timeofuse) are statistically insignificant in three of the equations, and it can be deduced that TOU pricing does not impact the decisions of a household to wait for a full load before using washing machine or dishwasher (Measure_load), install energy efficient appliances (Efficient_appliances), and install energy efficient light bulbs (Efficient_bulbs). In the other seven (7) statistically significant equations, varying electricity prices encourage households to implement energy saving measures and investments (Figure 4.1). As reported by the OECD (2011) study participants that had time varying electricity rates, reported having invested in energy saving equipment more than 
participants with flat electricity rates. This analysis confirms that having varying electricity pricing increases the likelihood of a household turning off lights when not in use (Measure_lights), cutting down heating/AC (Measure_heating), switching appliances to stand-by mode (Measure_standby), and turning-off appliances when not in use (Measure_applian). Moreover, this analysis demonstrates that TOU pricing has an impact on the likelihood of investing in energy saving activities, such as installing efficient thermal insulation (Efficient_insulation), efficient heating boiler (Efficient_heating), and renewable energy equipment (Renewable_energy). The high impact of TOU pricing on the decisions to install efficient thermal insulation and invest in renewable energy equipment could be due to the greater perceived long term savings as compared the initial financial investment. These results agree with the findings that varying electricity pricing are an improvement over flat electricity pricing and can lead to a decrease in energy consumption and increase in energy efficient investments, as described in Section 2.3.1.

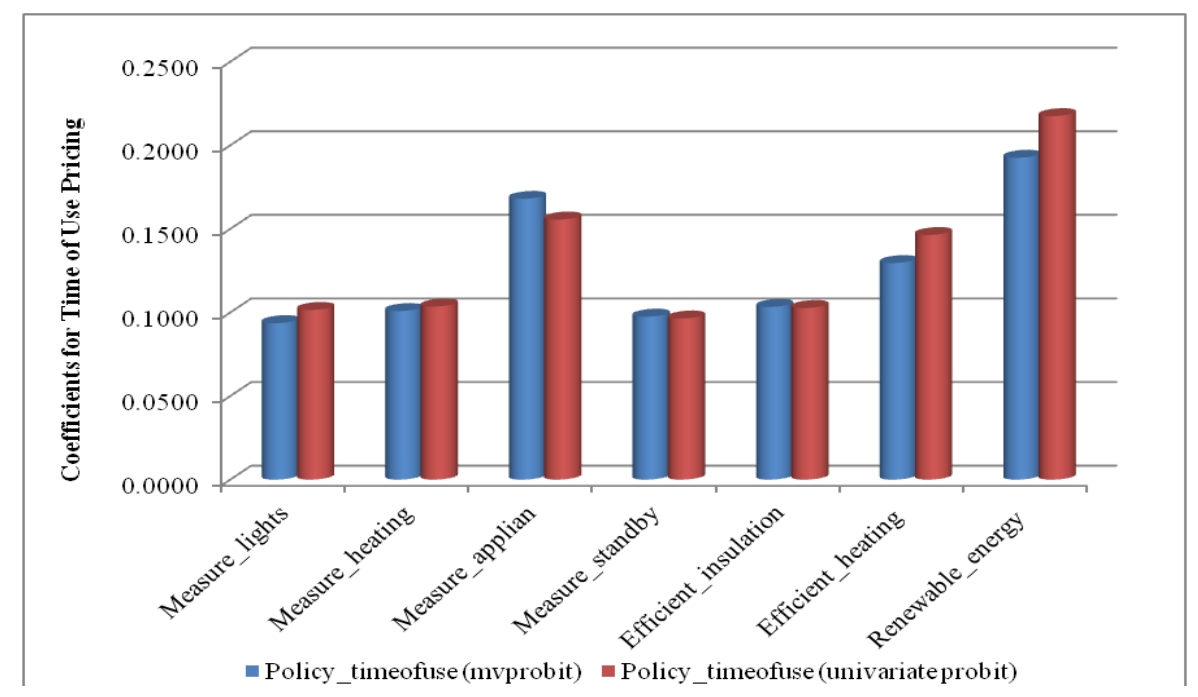

Figure 4.1. Effects of varying electricity pricing on energy saving measures and investments using the multivariate and univariate probit model. 


\subsubsection{Country Specific Characteristics}

There exist significant differences across countries in the 10 equations (measures and investments), thus it can be concluded that country specific factors play an important role in household's decision to implement energy saving measures and investments. After controlling for individual and household characteristics, it is observed that households in Korea are more likely to turn the lights off when leaving the room (Measure_lights) more than households in Sweden and Norway, but less likely than in any other participating country. In addition, households in Korea are more likely to cut down on heating/AC (Measure_heating) as an energy saving measure, but less likely to wait for a full load before using the washer/dryer (Measure_load) and turn-off appliances when not in use (Measure_appliances) than any other participating country. Moreover, households in Korea are more likely to turn appliances to standby mode when not in use (Measure_standby) than households in Australia and Czech Republic, but less likely than households in the rest of the countries.

Country specific effects are also observed in the level of energy saving investments partaken by households (Table 4.2). Households in Czech Republic are more likely to invest in energy efficient appliances (Efficient_appliances) than households in Korea, while countries such as Australia, Canada, Mexico, Sweden, and Norway are less likely to do so. Furthermore, the use of energy efficient bulbs (Efficient_bulbs) is less likely to be employed in households in Korea than households in any other participating country, which is also supported by the analysis of the OECD (2011) study. Thermal insulation (Efficient_insulation) and installation of efficient heating boiler (Efficient_heating) are investments more likely to be implemented in households in Netherlands than in Korea and any other country; all other participating countries are less likely to partake in these investments than Korea. Moreover, installation of renewable energy 
equipment (Renewable_energy) is more likely to occur in households in Korea. It is interesting to note that while all coefficient values are negative for the renewable energy variable, there are significant differences between countries. For example, Mexico (coefficient of -1.1554 and 1.1359) is less likely than all other countries to install renewable energy equipment. In summary, there is evidence suggesting that there are country specific factors that affect the level of households partaking in energy saving measures and investments. This could be due to many different factors such as cultural and educational factors, policy, energy prices, or weather conditions; however, the exact cause of these differences is difficult to determine without any additional information.

\subsubsection{Individual and Household Characteristics}

In this Section, the individual and household characteristics will be evaluated. It is worth noting that these are control variables that suggest tendencies and behaviours of households and are not the primary focus of this study. The following summary is based on statistically significant results only.

The results suggest that male participants are less likely than females to cut down on heating/AC (Measure_heating), wait for a full load before using the washer/dryer (Measure_load), and turn the appliances to standby when not in use (Measure_standby). However, being males are more likely than females to invest in renewable energy equipment (Renewable_energy). Generally, being married or living as a couple has a positive impact on the likelihood waiting for a full load before using the washer/dryer (Measure_load), invest in energy efficient appliances (Efficient_appliances), use of energy efficient bulbs (Efficient_bulbs) and installing thermal insulation (Efficient_insulation). As reported by Barr et al. (2005), older 
respondents are more likely to participate in energy saving measures. This study showed that participants that are older than 54 years (age_class_5) are more likely to partake in energy conserving measures such as turning the lights off when leaving the room (Measure_lights), cut down heating/AC (Measure_heating), turn-off appliances when not in use (Measure_applian), and switch off appliances to standby mode (Measure_standby). Participants that are between 45 and 54 years old (age_class_4) are more likely to wait for a full load before using washing machine/dishwasher (Measure_load). When it comes to energy efficient investments, participants older than 54 are less likely to invest in energy efficient appliances (Efficient_appliances) and renewable energy equipment (Renewable_energy); however, they are more likely to invest in energy efficient light bulbs (Efficient_bulbs), thermal insulation (Efficient_insulation), and efficient heating boiler(Efficient_heating).

Having a household income higher than $\$ 54,700$ negatively influences the likelihood of a household to partake in energy saving measures; however, a positive relation is observed on the likelihood of investing in energy efficient activities, such as installing energy efficient appliances, efficient thermal insulation, and efficient heating boiler. Looking at the coefficient, including the statistically insignificant ones, it is observed that generally higher incomes would allow people to invest on energy saving activities, agreeing with the results presented by Nair et al. (2010). The effects of occupation on the likelihood of adopting measures and investments concur with the effects of the income variable on the likelihood of adopting measures and investments. Participants that are executives, professionals, self-employed, and having a salaried position are less likely than manual workers to participate in energy saving measures, but more likely to invest in energy efficiency, such as investing in efficient appliances 
(Efficient_appliances), installing thermal insulation (Efficient_insulation), installing efficient heating boiler (Efficient_heating) and renewable energy equipment.

Employment is generally insignificant across the equations. Being employed part-time has a negative impact on the likelihood of turning-off appliances when not in use (Measure_appliances) and installing efficient appliances (Efficient_applinces). Participants employed full-time and part-time are more likely than unemployed participants to invest in efficient heating boiler (Efficient_heating) and renewable energy respectively. These results do not exhibit a specific pattern making it difficult to infer behaviour. A higher education level is related to a higher likelihood in partaking in energy efficient measure, such as waiting for a full load before using the washing machine (Measure_load) or turning off appliances when not in use (Measure_applian), and energy efficient investments, such as installing energy efficient appliances (Efficient_appliances), or energy efficient light bulbs (Efficient_bulbs).

Living in a house as compared to living in an apartment positively impacts the likelihood of installing efficient appliances (Efficient_applinces), energy efficient light bulbs (Efficient_bulbs), thermal insulation (Efficient_insulation), efficient heating boiler (Efficient_heating) and renewable energy equipments. Moreover, it positively impacts the likelihood of cutting down heating/AC (Measure_heating) and waiting for a full load before using the washer/dryer (Measure_load). Households in an urban or suburban area are less likely than households in rural or isolated areas to invest in energy efficient equipments such as, energy efficient light bulbs (Efficient_bulbs), thermal insulation (Efficient_insulation), efficient heating boiler (Efficient_heating) and renewable energy equipments. Moreover, they are less likely to switch off equipment to stand by when not in use (Measure_standby). 
Table 4.1. Comparison of coefficients from multivariate and univariate binary probit estimation results for energy efficient measures. Statistically insignificant results are marked in red.

\begin{tabular}{|c|c|c|c|c|c|c|c|c|c|c|}
\hline & \multicolumn{2}{|c|}{ Measure_lights } & \multicolumn{2}{|c|}{ Measure_heating } & \multicolumn{2}{|c|}{ Measure_load } & \multicolumn{2}{|c|}{ Measure_applian } & \multicolumn{2}{|c|}{ Measure_standby } \\
\hline & $\begin{array}{c}\text { Coefficient } \\
\text { (Multivariate) }\end{array}$ & $\begin{array}{c}\text { Coefficient } \\
\text { (Univariate) }\end{array}$ & $\begin{array}{c}\text { Coefficient } \\
\text { (Multivariate) }\end{array}$ & $\begin{array}{c}\text { Coefficient } \\
\text { (Univariate) }\end{array}$ & $\begin{array}{c}\text { Coefficient } \\
\text { (Multivariate) }\end{array}$ & $\begin{array}{c}\text { Coefficient } \\
\text { (Univariate) }\end{array}$ & $\begin{array}{c}\text { Coefficient } \\
\text { (Multivariate) }\end{array}$ & $\begin{array}{c}\text { Coefficient } \\
\text { (Univariate) }\end{array}$ & $\begin{array}{c}\text { Coefficient } \\
\text { (Multivariate) }\end{array}$ & $\begin{array}{c}\text { Coefficient } \\
\text { (Univariate) }\end{array}$ \\
\hline AUS & 0.3539 & 0.4132 & $\begin{array}{l}-0.4230 \\
\end{array}$ & $\begin{array}{l}-0.3699 \\
\end{array}$ & 0.4592 & 0.4987 & 0.0234 & 0.0581 & -0.3316 & -0.3223 \\
\hline CAN & 0.4382 & 0.5105 & -0.2395 & -0.1989 & 0.5211 & 0.5420 & 0.4611 & 0.5019 & 0.0191 & 0.0052 \\
\hline CZR & 0.2435 & 0.3549 & -0.3341 & -0.2753 & 0.5444 & 0.5913 & 0.2940 & 0.3471 & -0.2566 & -0.2524 \\
\hline FRA & 0.8402 & 0.9020 & -0.3051 & -0.2649 & 0.5888 & 0.6030 & 0.5830 & 0.6112 & 0.1578 & 0.1434 \\
\hline ITA & 0.3250 & 0.3266 & -0.2557 & -0.2109 & 0.5348 & 0.5129 & 0.4297 & 0.4531 & 0.1319 & 0.1416 \\
\hline MEX & 1.0427 & 1.1550 & -0.2157 & $\begin{array}{l}-0.1528 \\
\end{array}$ & 0.0215 & 0.0600 & 0.9128 & 1.0001 & 0.6791 & 0.6798 \\
\hline NLD & 0.0351 & 0.1099 & -0.4616 & -0.4001 & 0.6864 & 0.7355 & 0.6768 & 0.7178 & 0.4130 & 0.4138 \\
\hline SWE & -0.6526 & -0.5871 & $\begin{array}{l}-1.4788 \\
\end{array}$ & $\begin{array}{l}-1.4497 \\
\end{array}$ & 0.1917 & 0.2016 & 0.1244 & 0.1305 & 0.0576 & 0.0493 \\
\hline gender_male & -0.0311 & -0.0455 & -0.0677 & -0.0647 & -0.2294 & -0.2257 & -0.0458 & -0.0331 & -0.1389 & -0.1272 \\
\hline married & 0.0557 & 0.0656 & 0.0090 & 0.0179 & 0.1249 & 0.1494 & -0.0160 & 0.0072 & -0.0094 & 0.0053 \\
\hline income & -0.1055 & -0.1303 & -0.0551 & -0.0650 & -0.0213 & -0.0302 & -0.0179 & -0.0428 & -0.1311 & -0.1380 \\
\hline age_class_1 & -0.2764 & -0.2952 & -0.5263 & -0.5304 & -0.2853 & -0.3008 & -0.3449 & -0.3494 & -0.1684 & -0.1712 \\
\hline age_class_2 & $\begin{array}{l}-0.1968 \\
\end{array}$ & -0.2157 & -0.2850 & $\begin{array}{l}-0.2861 \\
\end{array}$ & -0.1402 & -0.1586 & -0.3110 & -0.3145 & -0.2007 & -0.2097 \\
\hline age_class_3 & $\begin{array}{l}-0.0379 \\
\end{array}$ & $\begin{array}{l}-0.0388 \\
\end{array}$ & $\begin{array}{l}-0.1098 \\
\end{array}$ & $\begin{array}{l}-0.1072 \\
\end{array}$ & 0.0941 & 0.0955 & -0.1348 & -0.1210 & -0.0815 & -0.0756 \\
\hline age_class_4 & -0.0145 & -0.0259 & -0.0894 & -0.0888 & 0.1570 & 0.1607 & 0.0233 & 0.0217 & -0.0059 & -0.0170 \\
\hline edu_1 & -0.0672 & -0.0841 & -0.0725 & -0.0828 & -0.1938 & -0.1695 & -0.1279 & -0.1292 & -0.0309 & -0.0617 \\
\hline edu_2 & 0.0907 & 0.0657 & $\begin{array}{c}-0.0609 \\
\end{array}$ & $\begin{array}{l}-0.0749 \\
\end{array}$ & $\begin{array}{l}-0.2018 \\
\end{array}$ & $\begin{array}{l}-0.1910 \\
\end{array}$ & -0.1557 & $\begin{array}{l}-0.1479 \\
\end{array}$ & $\begin{array}{c}-0.0001 \\
\end{array}$ & -0.0339 \\
\hline edu_4 & 0.0543 & 0.0442 & 0.0155 & 0.0145 & -0.0274 & $\begin{array}{l}-0.0004 \\
\end{array}$ & -0.0747 & -0.0531 & 0.0397 & 0.0328 \\
\hline empl_fulltime & 0.0078 & 0.0051 & 0.0848 & 0.0867 & -0.0215 & -0.0216 & -0.0046 & -0.0041 & 0.0092 & 0.0149 \\
\hline empl_parttime & -0.0944 & -0.1121 & 0.0588 & 0.0406 & -0.1163 & -0.1349 & -0.1536 & -0.1762 & -0.0382 & -0.0448 \\
\hline occup_executive & -0.1543 & -0.1615 & -0.0657 & -0.0637 & -0.3133 & -0.3196 & -0.1819 & -0.1811 & -0.0205 & -0.0150 \\
\hline occup_professionals & -0.0553 & -0.0823 & 0.0015 & $\begin{array}{l}-0.0071 \\
\end{array}$ & -0.1653 & -0.1743 & -0.0210 & $\begin{array}{l}-0.0311 \\
\end{array}$ & 0.0048 & 0.0051 \\
\hline occup_salaried & 0.0463 & 0.0668 & -0.0285 & -0.0143 & -0.0857 & -0.0600 & 0.0215 & 0.0431 & -0.0275 & -0.0071 \\
\hline occup_selfemployed & -0.0216 & -0.0326 & 0.0198 & 0.0095 & -0.0985 & -0.0965 & -0.1794 & -0.1965 & -0.1754 & -0.1731 \\
\hline type_house & $\begin{array}{c}-0.0068 \\
\end{array}$ & -0.0039 & 0.1371 & 0.1424 & 0.2293 & 0.2191 & 0.0022 & 0.0105 & -0.0061 & -0.0057 \\
\hline area_urban & -0.0239 & -0.0191 & -0.0678 & -0.0784 & -0.0438 & -0.0524 & -0.0829 & -0.0955 & -0.2038 & -0.2120 \\
\hline policy_TOU & 0.0936 & 0.1015 & 0.1009 & 0.1036 & -0.0099 & -0.0079 & 0.1680 & 0.1556 & 0.0975 & 0.0964 \\
\hline _cons & 1.1723 & 1.1459 & 1.1674 & 1.1349 & 1.0072 & 0.9765 & 1.0211 & 0.9859 & 0.4984 & 0.5118 \\
\hline
\end{tabular}

Notes:

1. empl_homemaker dropped because of collinearity

2. empl_retired dropped because of collinearity 
Table 4.2. Comparison of coefficients from multivariate and univariate binary probit estimation results for energy efficient investments. Statistically insignificant results are marked in red.

\begin{tabular}{|c|c|c|c|c|c|c|c|c|c|c|}
\hline & \multicolumn{2}{|c|}{ Efficient_appliances } & \multicolumn{2}{|c|}{ Efficient_bulbs } & \multicolumn{2}{|c|}{ Efficient_insulation } & \multicolumn{2}{|c|}{ Efficient_heating } & \multicolumn{2}{|c|}{ Renewable_energy } \\
\hline & $\begin{array}{c}\text { Coefficient } \\
\text { (Multivariate) } \\
\end{array}$ & $\begin{array}{c}\text { Coefficient } \\
\text { (Univariate) }\end{array}$ & $\begin{array}{c}\text { Coefficient } \\
\text { (Multivariate) } \\
\end{array}$ & $\begin{array}{c}\text { Coefficient } \\
\text { (Univariate) } \\
\end{array}$ & $\begin{array}{c}\text { Coefficient } \\
\text { (Multivariate) } \\
\end{array}$ & $\begin{array}{c}\text { Coefficient } \\
\text { (Univariate) } \\
\end{array}$ & $\begin{array}{c}\text { Coefficient } \\
\text { (Multivariate) } \\
\end{array}$ & $\begin{array}{c}\text { Coefficient } \\
\text { (Univariate) } \\
\end{array}$ & $\begin{array}{c}\text { Coefficient } \\
\text { (Multivariate) } \\
\end{array}$ & $\begin{array}{c}\text { Coefficient } \\
\text { (Univariate) } \\
\end{array}$ \\
\hline AUS & -0.3813 & -0.3811 & 0.2818 & 0.2985 & -0.3301 & -0.3123 & -0.4665 & -0.4531 & -0.4002 & -0.3990 \\
\hline CAN & -0.4465 & -0.4404 & 0.5226 & 0.5319 & -0.3824 & -0.3906 & -0.3527 & -0.3587 & -0.6861 & -0.6713 \\
\hline CZR & 0.3832 & 0.4244 & 0.7444 & 0.7604 & 0.0172 & 0.0162 & -0.7755 & -0.8191 & -0.7892 & -0.8186 \\
\hline FRA & 0.0311 & 0.0286 & 0.1543 & 0.1585 & $\begin{array}{l}-0.1078 \\
\end{array}$ & -0.1087 & $\begin{array}{l}-0.6010 \\
\end{array}$ & -0.5925 & $\begin{array}{l}-0.7666 \\
\end{array}$ & -0.7659 \\
\hline ITA & -0.0876 & -0.0717 & 0.7385 & 0.7446 & -0.1694 & -0.1638 & -0.3903 & -0.4055 & $\begin{array}{l}-0.1971 \\
\end{array}$ & -0.2136 \\
\hline MEX & -0.3611 & -0.3520 & 0.6328 & 0.6450 & -1.1997 & -1.2039 & -1.5279 & -1.5179 & -1.1554 & -1.1359 \\
\hline NLD & -0.1537 & -0.1397 & 0.1904 & 0.1973 & 0.1600 & 0.1495 & 0.6875 & 0.6838 & -0.6426 & -0.7079 \\
\hline SWE & -0.7575 & -0.7540 & 0.2484 & 0.2403 & -0.5938 & -0.5907 & -0.3584 & -0.3556 & -0.5196 & -0.4803 \\
\hline gender_male & -0.0176 & -0.0114 & -0.0278 & -0.0243 & 0.0420 & 0.0403 & 0.0026 & 0.0022 & 0.1196 & 0.1049 \\
\hline married & 0.2028 & 0.2029 & 0.1428 & 0.1487 & 0.1055 & 0.1053 & -0.0069 & -0.0144 & -0.0205 & -0.0176 \\
\hline income & 0.0774 & 0.0723 & 0.0665 & 0.0612 & 0.1064 & 0.1032 & 0.1040 & 0.1011 & 0.0633 & 0.0617 \\
\hline age_class_1 & -0.0805 & -0.0899 & -0.3716 & -0.3773 & -0.3184 & -0.3285 & 0.0855 & 0.0833 & 0.3264 & 0.3723 \\
\hline age_class_2 & 0.1336 & 0.1266 & -0.2651 & -0.2726 & -0.1633 & -0.1682 & -0.1061 & -0.1038 & 0.1258 & 0.1770 \\
\hline age_class_3 & 0.0687 & 0.0639 & -0.1690 & -0.1672 & -0.1141 & -0.1129 & -0.1028 & -0.1026 & -0.0144 & 0.0009 \\
\hline age_class_4 & 0.1522 & 0.1449 & -0.0941 & -0.0977 & 0.0262 & 0.0273 & -0.0854 & -0.0758 & 0.0781 & 0.0953 \\
\hline edu_1 & -0.1585 & -0.1502 & -0.1207 & -0.1160 & 0.0001 & -0.0030 & -0.0364 & -0.0440 & 0.0528 & 0.0328 \\
\hline edu_2 & -0.0208 & -0.0103 & -0.0756 & $\begin{array}{l}-0.0702 \\
\end{array}$ & -0.0308 & -0.0342 & $\begin{array}{l}-0.0700 \\
\end{array}$ & -0.0689 & $\begin{array}{l}-0.0469 \\
\end{array}$ & -0.0435 \\
\hline edu_4 & -0.1203 & -0.1093 & -0.1181 & -0.1053 & -0.0587 & -0.0603 & -0.0530 & -0.0506 & -0.0122 & -0.0141 \\
\hline empl_fulltime & -0.0727 & -0.0758 & 0.0645 & 0.0585 & -0.0441 & -0.0479 & 0.1596 & 0.1661 & 0.1278 & 0.1149 \\
\hline empl_parttime & -0.1822 & -0.1861 & 0.0876 & 0.0760 & -0.0858 & -0.0910 & 0.0864 & 0.1032 & 0.2112 & 0.2270 \\
\hline occup_executive & 0.0458 & 0.0535 & 0.0704 & 0.0675 & 0.2513 & 0.2515 & 0.1486 & 0.1357 & 0.3689 & 0.3554 \\
\hline occup_professionals & 0.0614 & 0.0650 & -0.0045 & -0.0087 & 0.1757 & 0.1750 & 0.1224 & 0.1208 & 0.2934 & 0.2830 \\
\hline occup_salaried & -0.0128 & -0.0066 & -0.0142 & -0.0078 & 0.1117 & 0.1151 & 0.0598 & 0.0591 & 0.0836 & 0.0716 \\
\hline occup_selfemployed & 0.1489 & 0.1458 & 0.0511 & 0.0546 & 0.1709 & 0.1672 & 0.1857 & 0.1827 & 0.1519 & 0.1523 \\
\hline type_house & 0.3062 & 0.3104 & 0.2780 & 0.2757 & 0.4751 & 0.4725 & 0.4375 & 0.4200 & 0.4291 & 0.3812 \\
\hline area_urban & 0.0063 & 0.0045 & -0.1131 & -0.1175 & -0.1401 & -0.1470 & -0.0907 & -0.0963 & -0.2710 & -0.2557 \\
\hline policy_TOU & 0.0528 & 0.0519 & 0.0303 & 0.0287 & 0.1034 & 0.1027 & 0.1296 & 0.1464 & 0.1926 & 0.2175 \\
\hline cons & 0.5300 & 0.5143 & 0.4832 & 0.4789 & $\begin{array}{c}-0.0848 \\
\end{array}$ & $\begin{array}{l}-0.0672 \\
\end{array}$ & $\begin{array}{l}-0.6888 \\
\end{array}$ & -0.6746 & -1.5691 & -1.5476 \\
\hline
\end{tabular}

Notes:

3. empl_homemaker dropped because of collinearity

4. empl_retired dropped because of collinearity 


\subsection{Probit Analysis of the Effects of Environmental Concern on Renewable Energy Purchase}

The participants of the survey were asked to rate their concern on environmental issues and whether or not they agreed with certain statements relating to environmental issues. In addition, the participants were asked whether they take any special measures to purchase renewable energy from their electricity provider (BUYRNWL). In this analysis, the effect of environmental concern on renewable energy purchase was evaluated as described in Section 3.2.3. The results of this evaluation are tabulated in Table 4.3 and visual representation is provided in Figure 4.2.

Table 4.3: Results of multivariate probit evaluation of the relation between environmental concern and renewable energy purchase. Values in red represent statistically insignificant results.

\begin{tabular}{|l|l|c|c|c|c|}
\hline \multicolumn{1}{|c|}{ Variable Name } & \multicolumn{1}{|c|}{ Variable Description } & Coefficient & $\begin{array}{c}\text { Std. } \\
\text { Err. }\end{array}$ & \multicolumn{1}{c|}{$\mathbf{z}$} & P>z \\
\hline \hline BETTRENV_LKRT & $\begin{array}{l}\text { Each individual/household can } \\
\text { contribute to a better } \\
\text { environment }\end{array}$ & & & & \\
\hline OVRSTATE_LKRT & $\begin{array}{l}\text { Environmental impacts are } \\
\text { frequently overstated }\end{array}$ & 0.2082 & 0.0462 & 4.5100 & 0.0000 \\
\hline FUTRGNRS_LKRT & $\begin{array}{l}\text { Environmental issues should be } \\
\text { dealt with primarily by future } \\
\text { generations }\end{array}$ & -0.0480 & 0.0472 & -1.0200 & 0.3090 \\
\hline TECHPROG_LKRT & $\begin{array}{l}\text { Environmental issues will be } \\
\text { resolved primarily through } \\
\text { technological progress }\end{array}$ & 0.0460 & 0.0426 & 1.0800 & 0.2810 \\
\hline NOTCOSTS_LKRT & $\begin{array}{l}\text { Environmental policies } \\
\text { introduced by the government to } \\
\text { address environmental issues } \\
\text { should not cost me extra money }\end{array}$ & -0.1835 & 0.0431 & -4.2600 & 0.0000 \\
\hline CLCH_LKRT & $\begin{array}{l}\text { Concern over climate change } \\
\text { (global warming) }\end{array}$ & 0.0314 & 0.0565 & 0.5600 & 0.5780 \\
\hline NRSC_LKRT & $\begin{array}{l}\text { Concern over natural resource } \\
\text { depletion (forest, water, energy) }\end{array}$ & 0.1386 & 0.0622 & 2.2300 & 0.0260 \\
\hline _cons (intercept) & N/A & -1.3838 & 0.1181 & -11.7100 & 0.0000 \\
\hline
\end{tabular}


As seen from Figure 4.2 most of the concerns are statistically insignificant and do not have an effect on the likelihood of a household purchasing renewable energy. Of the three equations that are statistically significant, two confirm with the expected outcome, while the other gives the opposite of what is expected. A strong and positive relation is observed between people agreeing with the statement that environmental impacts are frequently overstated (impacts_overstate) and purchase of renewable energy. Normally it is expected that people that believe that the environmental impacts are overstated would also believe that damage to the environment is not that significant and therefore opt to not purchase renewable energy. In this case people who have purchased renewable energy believe that environmental impacts are in fact overstated.

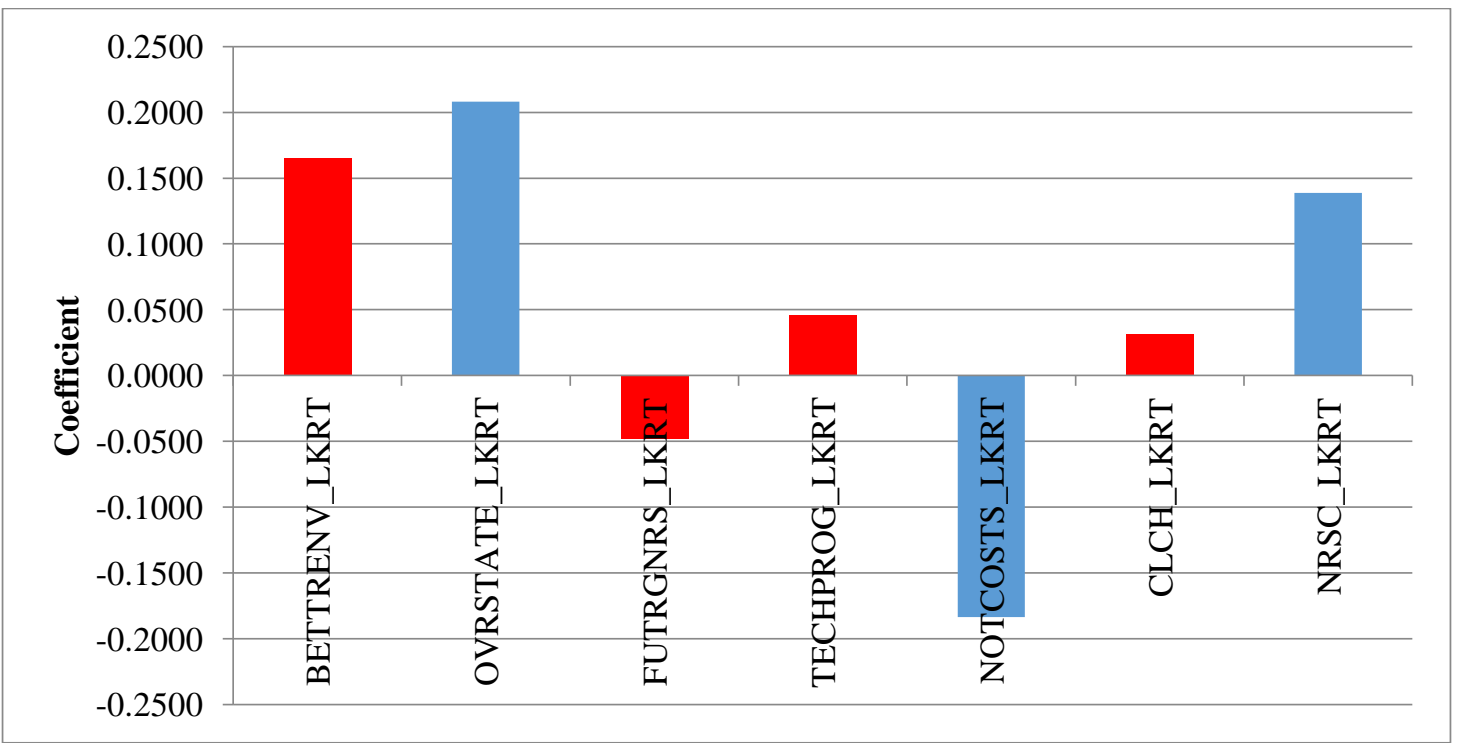

Figure 4.2: Results of probit model, evaluating the relationship between environmental concerns and purchase of renewable energy. The bars in red indicate statistically insignificant results.

Participants who believe that environmental policies introduced by the government to address environmental issues should not cost extra money are less likely to purchase renewable energy. This agrees with what would expect in this case: people who believe that addressing 
environmental issues will be associated with an increase in cost are also more likely to purchase renewable energy. Moreover, being concerned about natural resource depletion is positively related to the likelihood of purchasing renewable energy.

\subsection{Multivariate Probit Analysis of the Effects of Motivators on Measures and Investments}

The results of the probit analysis are tabulated in Appendix A and a graphical representation is presented in Figure 4.3. Generally, from statistically significant results, people who consider the motivators important are more likely to partake in energy efficient measures and investments (Table 4.4). There are, however, variations in the effects that the same motivators have in different energy saving measure and investments. For example, having more information on energy conservation (Mtv_information) appears to have a positive effect on the likelihood of turning off lights when leaving the room (Measure_lights), and cutting down on heating/AC (Measure_heating), however a negative effect is observed on the likelihood of waiting for a full load before using washing machine or dishwasher (Measure_load). These results suggest that it is not only important to shape policies depending on the country to be implemented, but also on the outcomes that the policy is trying to achieve. Another interesting observation is that having higher electricity prices (Mtv_price) does not appear to impact most of the measures and investments, suggesting that simply an increase in prices may not be the preferred solution when trying to promote energy saving measures and investments. Moreover, labels have a positive impact among most measures and investments, demonstrating the importance of labeling in influencing energy saving behaviour. 


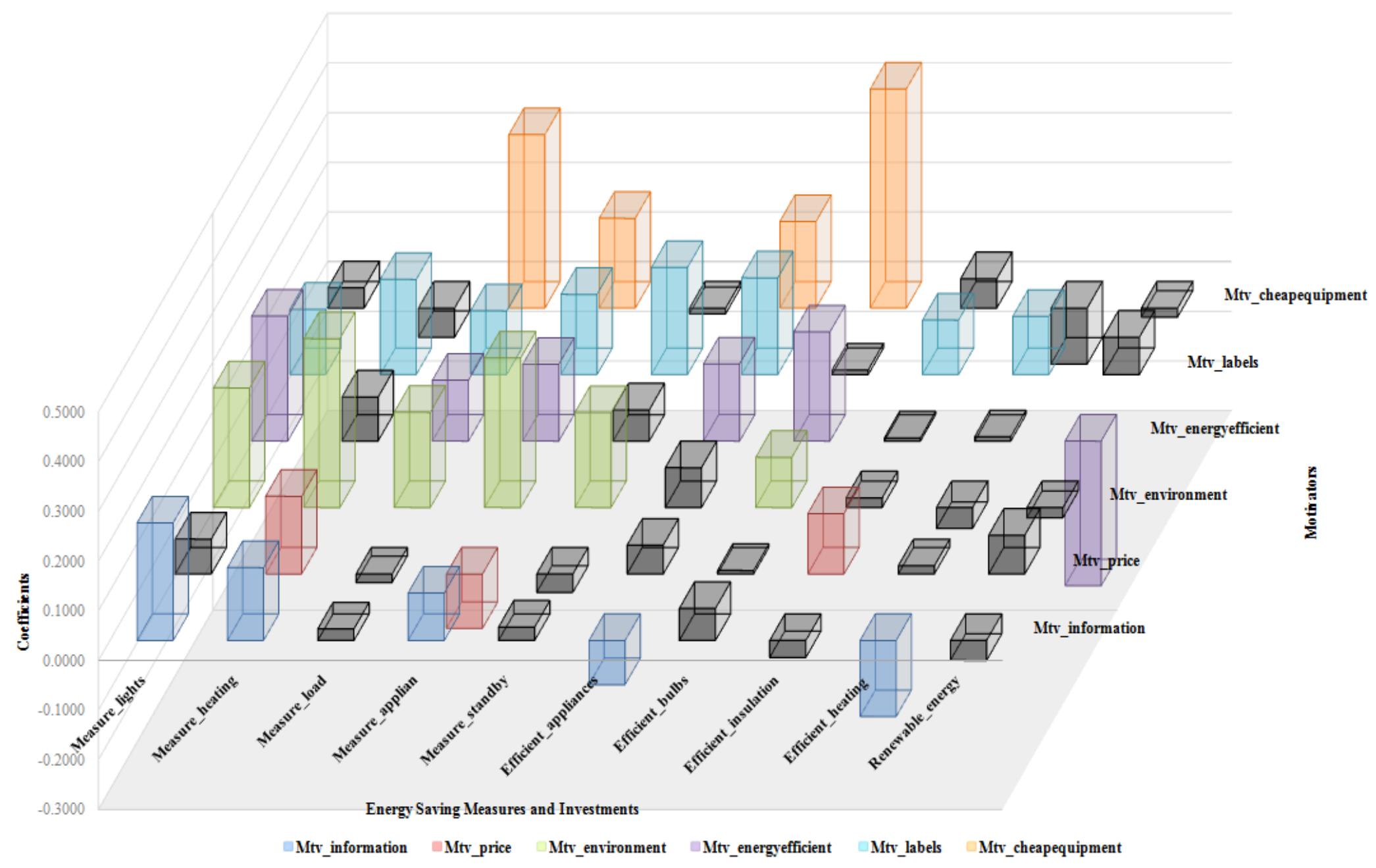

Figure 4.3. Multivariate probit analysis of the relationship of motivators and energy saving measures and investments. Positive coefficients indicates that households that consider the motivators important are more likely to partake in energy saving measures and investments. The greater the coefficient the stronger the relation. Bars in black color indicate statistically insignificant results. 
Table 4.4. Summary of the relation between motivators and Measures and Investments. (+) indicates a positive effect; (-) indicates a negative effect; and (x) indicates an insignificant effect.

\section{Motivators}

\begin{tabular}{|l||c|c|c|c|c|c|}
\hline & $\begin{array}{c}\text { Mtv_ } \\
\text { information }\end{array}$ & Mtv_price & $\begin{array}{c}\text { Mtv_ } \\
\text { environment }\end{array}$ & $\begin{array}{c}\text { Mtv___fient } \\
\text { energyefficient }\end{array}$ & $\begin{array}{c}\text { Mtv__ } \\
\text { labels }\end{array}$ & $\begin{array}{c}\text { Mtv__ } \\
\text { cheapequipment }\end{array}$ \\
\hline \hline Measure_lights & + & $\mathbf{x}$ & + & + & + & $\mathbf{x}$ \\
\hline Measure_heating & + & + & + & $\mathbf{x}$ & + & $\mathbf{x}$ \\
\hline Measure_load & $\mathbf{x}$ & $\mathbf{x}$ & + & $\mathbf{x}$ & + & + \\
\hline Measure_applian & + & - & + & + & + & + \\
\hline Measure_standby & $\mathbf{x}$ & $\mathbf{x}$ & + & $\mathbf{x}$ & + & $\mathbf{x}$ \\
\hline
\end{tabular}

To increase the probability of households installing efficient appliances (Efficient_applicances), a policy program that addresses the ease of identification of energy efficient labels (Mtv_labels) might be more successful than a program that addresses information on energy conservation (Mtv_information). Moreover, the results indicate that having more information on energy conservation (Mtv_information), belief on environmental benefits of actions (Mtv_environment), and availability of energy efficient products (Mtv_energyefficient), are strongly correlated with the probability of the household turning off lights when leaving the room (Measure_lights). Furthermore, belief on environmental benefits of the actions (Mtv_environment), easier identification of energy efficient labels (Mtv_labels), and less expensive energy efficient products (Mtv_cheapequipment) are positively correlated with the likelihood of a household turning off appliances when not in use (Measure_applian), and waiting for a full load before using the washing machine (Measure_load).

Generally the relation between motivators and energy efficient investments are not statistically significant. A strong relation is observed between the likelihood of a household 
installing energy efficient appliances (Efficient_appliances) and greater availability of energy efficient product (Mtv_energyefficient), easier identification of energy efficient labels (Mtv_labels), and less expensive energy efficient equipment (Mtv_cheapequipment); whereas a households' probability of installing low-energy light bulbs (Efficient_bulbs) is related to less expensive energy efficient equipment (Mtv_cheapequipment) and belief that the environmental benefits of actions are significant (Mtv_environment).

\subsection{Empirical Analysis of Motivators}

What people consider to be a good motivator can be used to decide which policy instrument is more likely to give the desired results. This can also be used to differentiate between the policies that are better suited for a specific country or groups of people. For example, if price is believed to be a good motivator by the population of a country, then a policy instrument that addresses price will be more successful, while in a country that considers information more important, a policy instrument that addresses public education might result in the desired outcome. Because of the significance of understanding what people consider important, an empirical analysis of what the population of each of the participating countries of this study considers as a good motivator for household energy reduction is evaluated.

The description of the empirical analysis is presented in Section 3.2.5 and the results are presented in Figure 4.4. Availability of energy efficient products (Mtv_energyefficient) is a strong motivator in all ten participating countries. This agrees with the results from OECD (2011) study where the average importance of each scaled response (not at all important $=0$, not important $=3.33$, fairly important $=6.66$ and very important $=10$ ) has been used. Moreover, the OECD study shows that availability of less expensive energy efficient products is the most 
important factor in encouraging people to reduce energy consumption in all 10 participating countries (OECD, 2011).

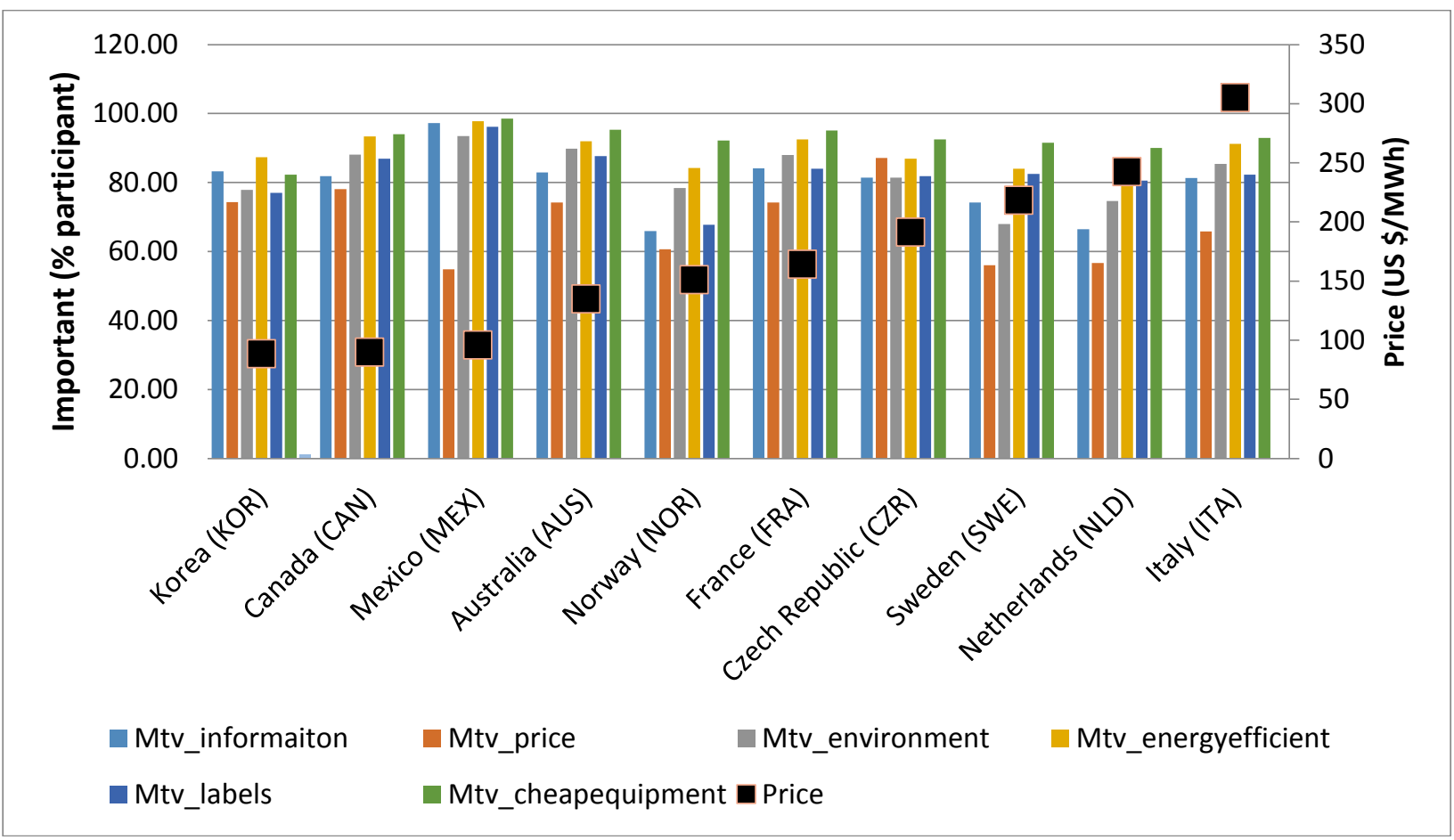

Figure 4.4: Importance of selected motivators as factor to reduce energy consumption. Prices obtained from IEA, 2012 and Simshauser, Nelson, \& Doan, 2010 (Price for Australia is the average of Queensland (QLD) and New South Wales (NSW)).

Easier identification of energy efficient labels (Mtv_labels) is generally considered a slightly lower motivator as compared to availability of energy efficient products (Mtv_energyefficient) and this difference between the two motivators is more pronounced for Norway where there is a $16 \%$ difference between the two motivators $(84.26 \%$ for Mtv_energyefficient and $67.80 \%$ for Mtv_labels). This is interesting as it is expected the two motivators to have comparable results, since if the need for more energy efficient products (Mtv_energyefficient) is important, than the need to have easily identifiable energy efficient 
labels should be similarly important. These results would suggest that people generally believe that more energy efficient products need to be introduced in the market.

The results of this analysis suggest that information on energy conservation (Mtv_information) is quite important in Mexico, however less significant in other countries. This could have to do with the information that is currently available in the country. A lack of such information, for example in Mexico, could explain why the participants of the survey would consider this to be a very important factor. Mexico was followed by France, Korea, Australia, Italy, Canada and Czech Republic, with Norway, Sweden and Netherlands having the lowest percentage of participants considering this motivator as an important factor in reducing energy consumption. Belief that environmental benefits are significant as a motivator (Mtv_environment) is more pronounced in Mexico, Australia, France, Italy, and Canada agreeing with the results of the OECD study (OECD, 2011).

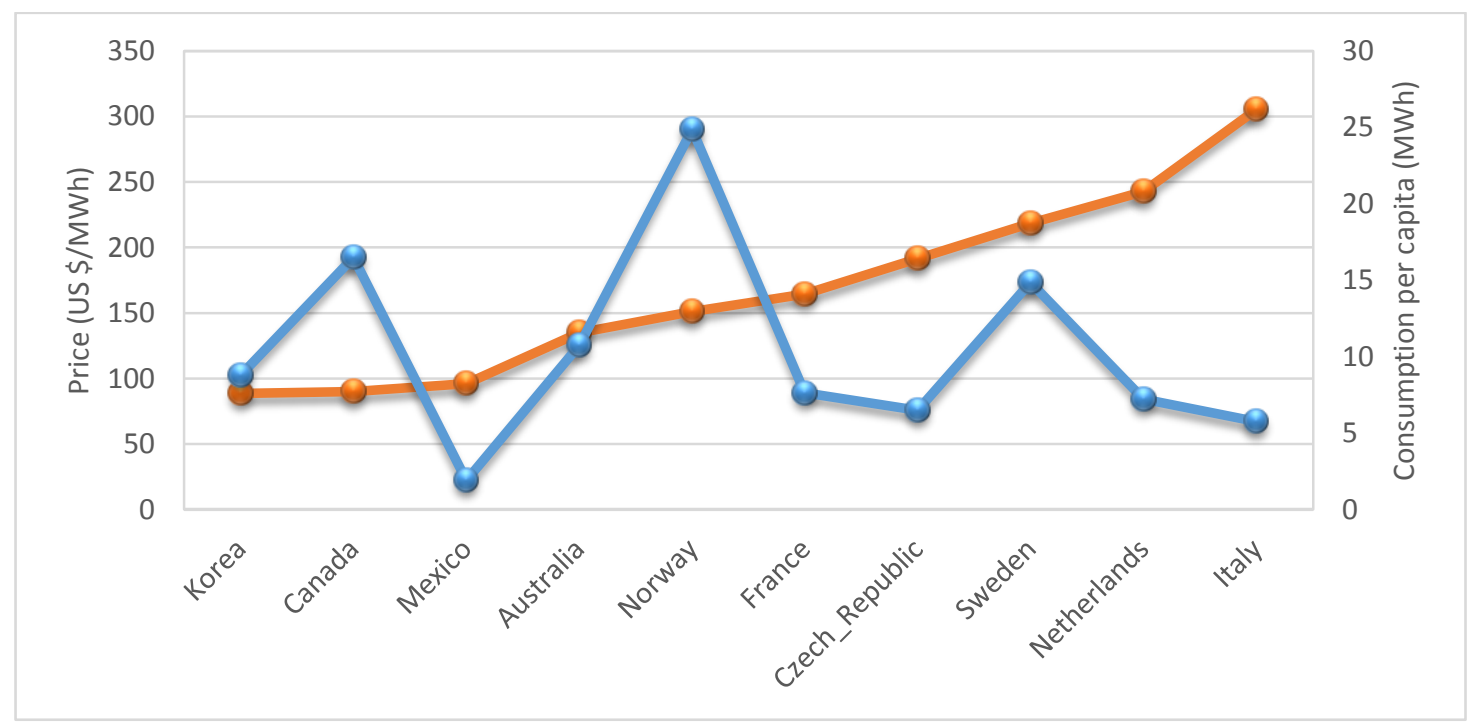

Figure 4.5. Energy consumption per capita (year 2008) and price of electricity (US $\$ / M W h$ ) for year 2008. Prices obtained from IEA, 2012 and Simshauser, Nelson, \& Doan, 2010 (Price for Australia is the average of Queensland (QLD) and New South Wales (NSW)). Consumption data obtained from "World Bank, 2014". 
A higher percentage of respondents in Czech Republic considers price to be an important motivator in reducing household energy consumption. Czech Republic is followed by Canada, Korea, Australia, and France. The country with the lowest percentage of people considering price as an important motivator was Mexico followed by the Netherlands, Italy, Sweden and Norway. Interestingly, as shown in Figure 4.5, Italy, that has the highest price per capita for electricity, considers price to be the least important motivator in decreasing household energy consumption. Comparing the price and consumption for each country, it can be seen that Italy has one of the lowest consumption levels per capita; since consumption is very low, an increase in price may not be perceived as an action that will have a major impact in household energy bill and therefore not a good motivator. 
Table 4.5: Summary of results of empirical analysis of motivators. Number of participants for each motivator is the number of participants surveyed that claimed that the motivator was fairly and very important.

\begin{tabular}{|c|c|c|c|c|c|c|c|}
\hline \multirow[b]{3}{*}{ Country } & \multirow[b]{3}{*}{$\begin{array}{c}\text { Total } \\
\text { participan } \\
\text { ts }\end{array}$} & \multicolumn{6}{|c|}{ MOTIVATORS } \\
\hline & & \multicolumn{2}{|c|}{ Mtv_information } & \multicolumn{2}{|c|}{ Mtv_price } & \multicolumn{2}{|c|}{ Mtv_environment } \\
\hline & & $\begin{array}{l}\text { No of participants } \\
\text { that selected fairly } \\
\text { and very important }\end{array}$ & $\begin{array}{c}\text { Percentage } \\
(\%)\end{array}$ & $\begin{array}{l}\text { No of participants } \\
\text { that selected fairly } \\
\text { and very important }\end{array}$ & $\begin{array}{c}\text { Percentage } \\
(\%)\end{array}$ & $\begin{array}{l}\text { No of participants } \\
\text { that selected fairly } \\
\text { and very important }\end{array}$ & $\begin{array}{c}\text { Percentage } \\
(\%)\end{array}$ \\
\hline Australia (AUS) & 511 & 424 & $82.97 \%$ & 379 & $74.17 \%$ & 459 & $89.82 \%$ \\
\hline Canada (CAN) & 556 & 455 & $81.83 \%$ & 434 & $78.06 \%$ & 490 & $88.13 \%$ \\
\hline Czech Republic (CZR) & 442 & 360 & $81.45 \%$ & 385 & $87.10 \%$ & 360 & $81.45 \%$ \\
\hline France (FRA) & 726 & 611 & $84.16 \%$ & 539 & $74.24 \%$ & 639 & $88.02 \%$ \\
\hline Italy (ITA) & 940 & 764 & $81.28 \%$ & 619 & $65.85 \%$ & 803 & $85.43 \%$ \\
\hline Korea (KOR) & 530 & 441 & $83.21 \%$ & 394 & $74.34 \%$ & 413 & $77.92 \%$ \\
\hline Mexico (MEX) & 680 & 661 & $97.21 \%$ & 373 & $54.85 \%$ & 636 & $93.53 \%$ \\
\hline Netherlands (NLD) & 411 & 273 & $66.42 \%$ & 233 & $56.69 \%$ & 307 & $74.70 \%$ \\
\hline Norway (NOR) & 705 & 465 & $65.96 \%$ & 428 & $60.71 \%$ & 553 & $78.44 \%$ \\
\hline Sweden (SWE) & 555 & 412 & $74.23 \%$ & 311 & $56.04 \%$ & 377 & $67.93 \%$ \\
\hline
\end{tabular}

\begin{tabular}{|c|c|c|c|c|c|c|c|}
\hline \multirow[b]{3}{*}{ Country } & \multirow[b]{3}{*}{$\begin{array}{c}\text { Total } \\
\text { participants }\end{array}$} & \multicolumn{6}{|c|}{ MOTIVATORS } \\
\hline & & \multicolumn{2}{|c|}{ Mtv_energyefficient } & \multicolumn{2}{|c|}{ Mtv_labels } & \multicolumn{2}{|c|}{ Mtv_cheapequipment } \\
\hline & & $\begin{array}{l}\text { No of participants } \\
\text { that selected fairly } \\
\text { and very important }\end{array}$ & $\begin{array}{c}\text { Percentage } \\
(\%)\end{array}$ & $\begin{array}{l}\text { No of participants } \\
\text { that selected fairly } \\
\text { and very important }\end{array}$ & $\begin{array}{c}\text { Percentage } \\
(\%)\end{array}$ & $\begin{array}{l}\text { No of participants } \\
\text { that selected fairly } \\
\text { and very important }\end{array}$ & $\begin{array}{c}\text { Percentage } \\
(\%)\end{array}$ \\
\hline Australia (AUS) & 511 & 470 & $91.98 \%$ & 448 & $87.67 \%$ & 487 & $95.30 \%$ \\
\hline Canada (CAN) & 556 & 519 & $93.35 \%$ & 483 & $86.87 \%$ & 523 & $94.06 \%$ \\
\hline Czech Republic (CZR) & 442 & 384 & $86.88 \%$ & 362 & $81.90 \%$ & 409 & $92.53 \%$ \\
\hline France (FRA) & 726 & 672 & $92.56 \%$ & 610 & $84.02 \%$ & 690 & $95.04 \%$ \\
\hline Italy (ITA) & 940 & 857 & $91.17 \%$ & 774 & $82.34 \%$ & 874 & $92.98 \%$ \\
\hline Korea (KOR) & 530 & 463 & $87.36 \%$ & 408 & $76.98 \%$ & 436 & $82.26 \%$ \\
\hline Mexico (MEX) & 680 & 665 & $97.79 \%$ & 654 & $96.18 \%$ & 670 & $98.53 \%$ \\
\hline Netherlands (NLD) & 411 & 359 & $87.35 \%$ & 331 & $80.54 \%$ & 370 & $90.02 \%$ \\
\hline Norway (NOR) & 705 & 594 & $84.26 \%$ & 478 & $67.80 \%$ & 650 & $92.20 \%$ \\
\hline Sweden (SWE) & 555 & 466 & $83.96 \%$ & 458 & $82.52 \%$ & 508 & $91.53 \%$ \\
\hline
\end{tabular}




\section{CHAPTER 5: SUMMARY AND CONCLUSION}

Addressing household energy consumption is important both because of the current consumption and its likely growth in the years to come. Policy instruments are an important tool used by governments to shape behaviour and promote change. As policy instruments vary greatly, selection of the appropriate instrument is a key factor in its success. This study examined households' energy usage practices based upon an analysis that accounts for the correlation between energy saving activities and a cross-country data set that allows for country specific effects. Significant differences are observed across the ten countries, indicating that country specific factors play an important role in household decision to implement energy saving measures and investments. It is observed that household in Czech Republic are more likely to invest in energy efficient appliances, while households in the Netherlands are more likely to install thermal insulation and efficient water heating boiler.

The effects of individual and household characteristics (control variables) on energy saving measures and behaviours were also evaluated, to provide an insight and the tendencies and behaviours of households. The results indicated that males are less likely than females to partake in energy saving measure and investments, while being married or living as a couple has a positive impact. Age was shown to have an impact on energy saving activities with older participants being more likely to partake in energy saving measure, but less likely to adopt energy efficient appliances (Efficient_appliances) and renewable energy equipment (Renewable_energy). Executives, professionals, self-employed and salaried individuals, along with higher income households are more likely to invest in energy efficient activities (investments) and renewable energy. 
Moreover, this study allows for the evaluation of the impact of time-of-use pricing scheme in different countries. The effects of varying electricity pricing did not appear to impact decisions of a household to wait for a full load before using washing machine or dishwasher, install energy efficient appliances, and install energy efficient light bulbs. However, this pricing scheme encourages households to implement energy saving measures and investments, and is especially impactful in the likelihood of a household turning off appliances when not in use, installing efficient heating boiler, and renewable energy technology. Purchase of renewable energy from energy provider on the other hand is influenced by the concern about natural resource depletion. Lastly, this study showed that generally people who considered the motivators important were more likely to partake in energy efficient measures and investments. Specifically, strong relationships are observed between availability of less expensive efficient equipment and the likelihood of a household waiting for a full load before using the washing machine, turn off appliances when not in use, and install energy efficient appliances and thermal insulation. Moreover, strong positive relations are observed between all measures and belief that environmental benefits of actions are significant.

In summary, there are a few relevant conclusions that can be drawn from this analysis: First, there are complementary effects between the energy saving measures and investments that should be considered when assessing a policy instrument. Second, economic instruments, such as time varying rates, display desirable effect on energy saving behaviour across most measures and investments. Lastly, concern over environmental problems or natural resources is an important aspect that should be considered when selecting a policy instrument. 


\subsection{Study Limitations}

The responses to the survey were self-reported and it is difficult to compare the results of one respondent with another. Moreover, time of use pricing scheme was a fairly new policy in 2008; however the analysis provides a good insight into the effect of such policy in participating countries.

\subsection{Future Work}

Future work to follow this study would be to undertake the same survey at a later time (in 2018 for example) and compare whether there are any changes in people's responses. The results of the same survey in the future could also be used to evaluate whether TOU policy has caused a decrease in energy consumption. It should be noted, however, that a much larger sample size is needed since an analysis as the one performed on this project decreases the sample size by removing the observations left blank or marked as "don't know". 


\section{APPENDICES}

\section{APPENDIX A: Results of multivariate probit analysis of motivators}

Table A1. Results of multivariate probit analysis of motivators describing the relation of motivators and energy saving measures.

Results of this analysis are discussed in Section 3.2.4. Coefficients in red are statistically insignificant.

\begin{tabular}{|c|c|c|c|c|c|c|c|c|c|c|c|c|c|c|c|}
\hline & \multicolumn{3}{|c|}{ Measure_lights } & \multicolumn{3}{|c|}{ Measure_heating } & \multicolumn{3}{|c|}{ Measure_load } & \multicolumn{3}{|c|}{ Measure_applian } & \multicolumn{3}{|c|}{ Measure_standby } \\
\hline & Coefficient & Std. Err. & $\mathrm{P}>\mathrm{z}$ & Coefficient & Std. Err. & $\mathrm{P}>\mathrm{z}$ & Coefficient & Std. Err. & $\mathrm{P}>\mathrm{Z}$ & Coefficient & Std. Err. & $\mathrm{P}>\mathrm{z}$ & Coefficient & Std. Err. & $\mathrm{P}>\mathrm{Z}$ \\
\hline Mtv_information & 0.2368 & 0.0562 & 4.2100 & 0.1466 & 0.0478 & 3.0700 & 0.0233 & 0.0570 & 0.4100 & 0.0956 & 0.0538 & 1.7800 & 0.0270 & 0.0460 & 0.5900 \\
\hline Mtv_price & 0.0703 & 0.0460 & 1.5300 & 0.1565 & 0.0370 & 4.2300 & -0.0171 & 0.0446 & -0.3800 & -0.1096 & 0.0436 & -2.5100 & -0.0370 & 0.0353 & -1.0500 \\
\hline Mtv_environment & 0.2409 & 0.0601 & 4.0100 & 0.3400 & 0.0508 & 6.6900 & 0.1917 & 0.0596 & 3.2200 & 0.3012 & 0.0570 & 5.2800 & 0.1913 & 0.0497 & 3.8500 \\
\hline Mtv_energyefficient & 0.2518 & 0.0796 & 3.1600 & 0.0886 & 0.0697 & 1.2700 & 0.1227 & 0.0799 & 1.5400 & 0.1547 & 0.0761 & 2.0300 & 0.0626 & 0.0678 & 0.9200 \\
\hline Mtv_labels & 0.1315 & 0.0652 & 2.0200 & 0.1916 & 0.0545 & 3.5200 & 0.1284 & 0.0642 & 2.0000 & 0.1615 & 0.0611 & 2.6400 & 0.2156 & 0.0527 & 4.0900 \\
\hline Mtv_cheapequipment & 0.0409 & 0.0859 & 0.4800 & -0.0590 & 0.0755 & -0.7800 & 0.3494 & 0.0812 & 4.3000 & 0.1808 & 0.0806 & 2.2400 & -0.0114 & 0.0727 & -0.1600 \\
\hline _cons & 0.4056 & 0.0759 & 5.3400 & $\begin{array}{l}-0.1099 \\
\end{array}$ & 0.0692 & -1.5900 & 0.4186 & 0.0730 & 5.7300 & 0.3599 & 0.0734 & 4.9100 & -0.1172 & 0.0677 & -1.7300 \\
\hline
\end{tabular}

Table A2. Results of multivariate probit analysis of motivators describing the relation of motivators and energy saving investments. Results of this analysis are discussed in Section 3.2.4. Coefficients in red are statistically insignificant.

\begin{tabular}{|c|c|c|c|c|c|c|c|c|c|c|c|c|c|c|c|}
\hline & \multicolumn{3}{|c|}{ Efficient_appliances } & \multicolumn{3}{|c|}{ Efficient_bulbs } & \multicolumn{3}{|c|}{ Efficient_insulation } & \multicolumn{3}{|c|}{ Efficient_heating } & \multicolumn{3}{|c|}{ Renewable_energy } \\
\hline & Coefficient & Std. Err. & $\mathrm{P}>\mathrm{Z}$ & Coefficient & Std. Err. & $\mathrm{P}>\mathrm{Z}$ & Coefficient & Std. Err. & $\mathrm{P}>\mathrm{Z}$ & Coefficient & Std. Err. & $\mathrm{P}>\mathrm{Z}$ & Coefficient & $\begin{array}{l}\text { Std. } \\
\text { Err. }\end{array}$ & $\mathrm{P}>\mathrm{Z}$ \\
\hline Mtv_information & -0.0892 & 0.0493 & -1.8100 & 0.0646 & 0.0519 & 1.2500 & -0.0343 & 0.0459 & -0.7500 & -0.1532 & 0.0491 & -3.1200 & -0.0401 & 0.0649 & -0.6200 \\
\hline Mtv_price & 0.0579 & 0.0374 & 1.5500 & 0.0071 & 0.0406 & 0.1700 & 0.1217 & 0.0352 & 3.4600 & 0.0166 & 0.0384 & 0.4300 & 0.0781 & 0.0515 & 1.5200 \\
\hline Mtv_environment & 0.0802 & 0.0525 & 1.5300 & 0.1011 & 0.0560 & 1.8100 & 0.0195 & 0.0499 & 0.3900 & -0.0418 & 0.0540 & -0.7700 & -0.0204 & 0.0709 & -0.2900 \\
\hline Mtv_energyefficient & 0.1554 & 0.0707 & 2.2000 & 0.2197 & 0.0742 & 2.9600 & 0.0061 & 0.0686 & 0.0900 & 0.0087 & 0.0744 & 0.1200 & -0.2912 & 0.0915 & -3.1800 \\
\hline Mtv_labels & 0.1948 & 0.0553 & 3.5200 & 0.0093 & 0.0603 & 0.1500 & 0.1097 & 0.0530 & 2.0700 & 0.1174 & 0.0581 & 2.0200 & 0.0752 & 0.0767 & 0.9800 \\
\hline Mtv_cheapequipment & 0.1745 & 0.0747 & 2.3400 & 0.4413 & 0.0761 & 5.8000 & 0.0592 & 0.0729 & 0.8100 & -0.1128 & 0.0777 & -1.4500 & -0.0183 & 0.0993 & -0.1800 \\
\hline _cons & 0.0752 & 0.0686 & 1.1000 & 0.1164 & 0.0691 & 1.6900 & -0.3092 & 0.0681 & -4.5400 & -0.5645 & 0.0717 & -7.8800 & -1.1848 & 0.0885 & -13.3900 \\
\hline
\end{tabular}


APPENDIX B: Results of multivariate binary probit for energy efficient measures and investments

Table B1. Multivariate binary probit estimation results for energy efficient measures.

\begin{tabular}{|c|c|c|c|c|c|c|c|c|c|c|c|c|c|c|c|}
\hline & \multicolumn{3}{|c|}{ Measure_lights } & \multicolumn{3}{|c|}{ Measure_heating } & \multicolumn{3}{|c|}{ Measure_load } & \multicolumn{3}{|c|}{ Measure_applian } & \multicolumn{3}{|c|}{ Measure_standby } \\
\hline & Coefficient & Std. Err. & $\mathrm{P}>\mathrm{Z}$ & Coefficient & Std. Err. & $\mathrm{P}>\mathrm{Z}$ & Coefficient & Std. Err. & $\mathrm{P}>\mathrm{Z}$ & Coefficient & Std. Err. & $\mathrm{P}>\mathrm{Z}$ & Coefficient & Std. Err. & $\overline{\mathrm{P}>\mathrm{Z}}$ \\
\hline AUS & 0.3539 & 0.1121 & 0.0020 & -0.4230 & 0.0937 & 0.0000 & 0.4592 & 0.1012 & 0.0000 & 0.0234 & 0.0906 & 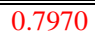 & -0.3316 & 0.0819 & 0.0000 \\
\hline CAN & 0.4382 & 0.1095 & 0.0000 & -0.2395 & 0.0914 & 0.0090 & 0.5211 & 0.0977 & 0.0000 & 0.4611 & 0.0919 & 0.0000 & 0.0191 & 0.0780 & 0.8070 \\
\hline CZR & 0.2435 & 0.1159 & 0.0360 & -0.3341 & 0.0970 & 0.0010 & 0.5444 & 0.1077 & 0.0000 & 0.2940 & 0.0987 & 0.0030 & -0.2566 & 0.0855 & 0.0030 \\
\hline FRA & 0.8402 & 0.1229 & 0.0000 & -0.3051 & 0.0894 & 0.0010 & 0.5888 & 0.0956 & 0.0000 & 0.5830 & 0.0933 & 0.0000 & 0.1578 & 0.0778 & 0.0430 \\
\hline ITA & 0.3250 & 0.0947 & 0.0010 & -0.2557 & 0.0829 & 0.0020 & 0.5348 & 0.0847 & 0.0000 & 0.4297 & 0.0819 & 0.0000 & 0.1319 & 0.0706 & 0.0620 \\
\hline MEX & 1.0427 & 0.1383 & 0.0000 & -0.2157 & 0.0906 & 0.0170 & 0.0215 & 0.0876 & 0.8070 & 0.9128 & 0.1023 & 0.0000 & 0.6791 & 0.0809 & 0.0000 \\
\hline NLD & 0.0351 & 0.1082 & 0.7450 & -0.4616 & 0.0960 & 0.0000 & 0.6864 & 0.1142 & 0.0000 & 0.6768 & 0.1075 & 0.0000 & 0.4130 & 0.0877 & 0.0000 \\
\hline NOR & -0.3835 & 0.0919 & 0.0000 & -0.8635 & 0.0860 & 0.0000 & 0.3533 & 0.0911 & 0.0000 & 0.3209 & 0.0877 & 0.0000 & 0.2389 & 0.0773 & 0.0020 \\
\hline SWE & -0.6526 & 0.0912 & 0.0000 & -1.4788 & 0.0888 & 0.0000 & 0.1917 & 0.0904 & 0.0340 & 0.1244 & 0.0869 & 0.1520 & 0.0576 & 0.0785 & 0.4630 \\
\hline gender_male & -0.0311 & 0.0483 & 0.5190 & -0.0677 & 0.0381 & 0.0760 & -0.2294 & 0.0452 & 0.0000 & -0.0458 & 0.0431 & 0.2880 & -0.1389 & 0.0354 & 0.0000 \\
\hline Married & 0.0557 & 0.0501 & 0.2660 & 0.0090 & 0.0399 & 0.8210 & 0.1249 & 0.0460 & 0.0070 & -0.0160 & 0.0450 & 0.7220 & $\begin{array}{l}-0.0094 \\
\end{array}$ & 0.0370 & 0.8000 \\
\hline Income & -0.1055 & 0.0488 & 0.0310 & -0.0551 & 0.0380 & 0.1480 & -0.0213 & 0.0444 & 0.6310 & -0.0179 & 0.0430 & 0.6770 & -0.1311 & 0.0352 & 0.0000 \\
\hline age_class_1 & -0.2764 & 0.1036 & 0.0080 & -0.5263 & 0.0824 & 0.0000 & -0.2853 & 0.0932 & 0.0020 & -0.3449 & 0.0921 & 0.0000 & -0.1684 & 0.0784 & 0.0320 \\
\hline age_class_2 & $\begin{array}{l}-0.1968 \\
\end{array}$ & 0.0773 & 0.0110 & -0.2850 & 0.0629 & 0.0000 & -0.1402 & 0.0730 & 0.0550 & -0.3110 & 0.0702 & 0.0000 & -0.2007 & 0.0579 & 0.0010 \\
\hline age_class_3 & -0.0379 & 0.0740 & 0.6090 & -0.1098 & 0.0604 & 0.0690 & 0.0941 & 0.0720 & 0.1910 & -0.1348 & 0.0674 & 0.0460 & -0.0815 & 0.0551 & 0.1390 \\
\hline age_class_4 & -0.0145 & 0.0736 & 0.8430 & -0.0894 & 0.0595 & 0.1330 & 0.1570 & 0.0723 & 0.0300 & 0.0233 & 0.0684 & 0.7330 & -0.0059 & 0.0547 & 0.9140 \\
\hline edu_1 & -0.0672 & 0.1080 & 0.5340 & -0.0725 & 0.0838 & 0.3870 & -0.1938 & 0.1009 & 0.0550 & -0.1279 & 0.0963 & 0.1840 & $\begin{array}{l}-0.0309 \\
\end{array}$ & 0.0776 & 0.6910 \\
\hline edu_2 & 0.0907 & 0.0874 & 0.2990 & -0.0609 & 0.0695 & 0.3810 & -0.2018 & 0.0821 & 0.0140 & -0.1557 & 0.0791 & 0.0490 & -0.0001 & 0.0641 & 0.9990 \\
\hline edu_3 & 0.0081 & 0.0850 & 0.9240 & -0.0192 & 0.0668 & 0.7740 & -0.1343 & 0.0789 & 0.0890 & -0.1505 & 0.0771 & 0.0510 & 0.0340 & 0.0618 & 0.5820 \\
\hline edu_4 & 0.0543 & 0.0776 & 0.4840 & 0.0155 & 0.0627 & 0.8050 & -0.0274 & 0.0738 & 0.7100 & -0.0747 & 0.0728 & 0.3050 & 0.0397 & 0.0581 & 0.4940 \\
\hline empl_fulltime & 0.0078 & 0.0765 & 0.9190 & 0.0848 & 0.0614 & 0.1670 & -0.0215 & 0.0741 & 0.7720 & -0.0046 & 0.0703 & 0.9480 & 0.0092 & 0.0566 & 0.8700 \\
\hline empl_leave & -0.0914 & 0.1524 & 0.5490 & 0.0341 & 0.1273 & 0.7890 & -0.0040 & 0.1625 & 0.9810 & -0.0578 & 0.1426 & 0.6850 & -0.1267 & 0.1180 & 0.2830 \\
\hline empl_parttime & -0.0944 & 0.0934 & 0.3120 & 0.0588 & 0.0751 & 0.4340 & -0.1163 & 0.0897 & 0.1940 & -0.1536 & 0.0841 & 0.0680 & -0.0382 & 0.0693 & 0.5820 \\
\hline occup_executive & -0.1543 & 0.0877 & 0.0790 & -0.0657 & 0.0718 & 0.3600 & -0.3133 & 0.0846 & 0.0000 & -0.1819 & 0.0791 & 0.0210 & -0.0205 & 0.0669 & 0.7590 \\
\hline occup_professionals & -0.0553 & 0.0913 & 0.5440 & 0.0015 & 0.0746 & 0.9840 & -0.1653 & 0.0883 & 0.0610 & -0.0210 & 0.0829 & 0.8000 & 0.0048 & 0.0693 & 0.9440 \\
\hline occup_salaried & 0.0463 & 0.0744 & 0.5340 & -0.0285 & 0.0608 & 0.6400 & -0.0857 & 0.0733 & 0.2420 & 0.0215 & 0.0670 & 0.7480 & -0.0275 & 0.0565 & 0.6270 \\
\hline occup_selfemployed & -0.0216 & 0.1025 & 0.8330 & 0.0198 & 0.0830 & 0.8120 & -0.0985 & 0.0978 & 0.3140 & -0.1794 & 0.0884 & 0.0420 & -0.1754 & 0.0756 & 0.0200 \\
\hline type_house & -0.0068 & 0.0524 & 0.8970 & 0.1371 & 0.0418 & 0.0010 & 0.2293 & 0.0482 & 0.0000 & 0.0022 & 0.0466 & 0.9630 & -0.0061 & 0.0386 & 0.8750 \\
\hline area_urban & -0.0239 & 0.0564 & 0.6720 & -0.0678 & 0.0456 & 0.1370 & -0.0438 & 0.0561 & 0.4340 & -0.0829 & 0.0517 & 0.1090 & -0.2038 & 0.0425 & 0.0000 \\
\hline policy_TOU & 0.0936 & 0.0526 & 0.0750 & 0.1009 & 0.0399 & 0.0110 & -0.0099 & 0.0467 & 0.8320 & 0.1680 & 0.0454 & 0.0000 & 0.0975 & 0.0364 & 0.0070 \\
\hline _cons & 1.1723 & 0.1569 & 0.0000 & 1.1674 & 0.1318 & 0.0000 & 1.0072 & 0.1495 & 0.0000 & 1.0211 & 0.1421 & 0.0000 & 0.4984 & 0.1187 & 0.0000 \\
\hline
\end{tabular}

Notes:

1. empl_homemaker dropped because of collinearity

2. empl_retired dropped because of collinearity 
Table B2. Multivariate binary probit estimation results for energy efficient investments.

\begin{tabular}{|c|c|c|c|c|c|c|c|c|c|c|c|c|c|c|c|}
\hline & \multicolumn{3}{|c|}{ Efficient_applicances } & \multicolumn{3}{|c|}{ Efficient_bulbs } & \multicolumn{3}{|c|}{ Efficient_insulation } & \multicolumn{3}{|c|}{ Efficient_heating } & \multicolumn{3}{|c|}{ Renewable_energy } \\
\hline & Coefficient & Std. Err. & $\mathrm{P}>\mathrm{z}$ & Coefficient & Std. Err. & $\mathrm{P}>\mathrm{z}$ & Coefficient & Std. Err. & $\mathrm{P}>\mathrm{Z}$ & Coefficient & $\begin{array}{l}\text { Std. Err. } \\
\end{array}$ & $\mathrm{P}>\mathrm{Z}$ & Coefficient & Std. Err. & $\mathrm{P}>\mathrm{Z}$ \\
\hline AUS & -0.3813 & 0.0891 & 0.0000 & 0.2818 & 0.0902 & 0.0020 & -0.3301 & 0.0834 & 0.0000 & -0.4665 & 0.0870 & 0.0000 & -0.4002 & 0.1086 & 0.0000 \\
\hline CAN & -0.4465 & 0.0847 & 0.0000 & 0.5226 & 0.0883 & 0.0000 & -0.3824 & 0.0799 & 0.0000 & -0.3527 & 0.0830 & 0.0000 & -0.6861 & 0.1181 & 0.0000 \\
\hline CZR & 0.3832 & 0.1047 & 0.0000 & 0.7444 & 0.1024 & 0.0000 & 0.0172 & 0.0866 & 0.8420 & -0.7755 & 0.1003 & 0.0000 & -0.7892 & 0.1426 & 0.0000 \\
\hline FRA & 0.0311 & 0.0875 & 0.7220 & 0.1543 & 0.0835 & 0.0650 & -0.1078 & 0.0793 & 0.1740 & -0.6010 & 0.0849 & 0.0000 & -0.7666 & 0.1163 & 0.0000 \\
\hline ITA & -0.0876 & 0.0779 & 0.2610 & 0.7385 & 0.0799 & 0.0000 & -0.1694 & 0.0711 & 0.0170 & -0.3903 & 0.0755 & 0.0000 & -0.1971 & 0.0942 & 0.0370 \\
\hline MEX & -0.3611 & 0.0850 & 0.0000 & 0.6328 & 0.0890 & 0.0000 & -1.1997 & 0.0837 & 0.0000 & -1.5279 & 0.1030 & 0.0000 & -1.1554 & 0.1273 & 0.0000 \\
\hline NLD & -0.1537 & 0.0933 & 0.1000 & 0.1904 & 0.0910 & 0.0360 & 0.1600 & 0.0875 & 0.0670 & 0.6875 & 0.0880 & 0.0000 & -0.6426 & 0.1267 & 0.0000 \\
\hline NOR & -0.5366 & 0.0824 & 0.0000 & 0.3203 & 0.0836 & 0.0000 & -0.6116 & 0.0775 & 0.0000 & -0.6145 & 0.0829 & 0.0000 & 0.0392 & 0.0958 & 0.6830 \\
\hline SWE & -0.7575 & 0.0843 & 0.0000 & 0.2484 & 0.0843 & 0.0030 & -0.5938 & 0.0818 & 0.0000 & -0.3584 & 0.0855 & 0.0000 & -0.5196 & 0.1162 & 0.0000 \\
\hline gender_male & -0.0176 & 0.0379 & 0.6420 & -0.0278 & 0.0409 & 0.4960 & 0.0420 & 0.0362 & 0.2460 & 0.0026 & 0.0403 & 0.9480 & 0.1196 & 0.0534 & 0.0250 \\
\hline married & 0.2028 & 0.0390 & 0.0000 & 0.1428 & 0.0417 & 0.0010 & 0.1055 & 0.0380 & 0.0050 & -0.0069 & 0.0423 & 0.8710 & -0.0205 & 0.0563 & 0.7160 \\
\hline income & 0.0774 & 0.0379 & 0.0410 & 0.0665 & 0.0412 & 0.1070 & 0.1064 & 0.0359 & 0.0030 & 0.1040 & 0.0400 & 0.0090 & 0.0633 & 0.0522 & 0.2260 \\
\hline age_class_1 & -0.0805 & 0.0810 & 0.3210 & -0.3716 & 0.0873 & 0.0000 & -0.3184 & 0.0817 & 0.0000 & 0.0855 & 0.0872 & 0.3260 & 0.3264 & 0.1120 & 0.0040 \\
\hline age_class_2 & 0.1336 & 0.0619 & 0.0310 & -0.2651 & 0.0680 & 0.0000 & -0.1633 & 0.0590 & 0.0060 & -0.1061 & 0.0648 & 0.1020 & 0.1258 & 0.0844 & 0.1360 \\
\hline age_class_3 & 0.0687 & 0.0587 & 0.2420 & -0.1690 & 0.0657 & 0.0100 & -0.1141 & 0.0559 & 0.0410 & -0.1028 & 0.0610 & 0.0920 & -0.0144 & 0.0807 & 0.8580 \\
\hline age_class_4 & 0.1522 & 0.0588 & 0.0100 & -0.0941 & 0.0656 & 0.1510 & 0.0262 & 0.0552 & 0.6350 & -0.0854 & 0.0608 & 0.1600 & 0.0781 & 0.0793 & 0.3250 \\
\hline edu_1 & -0.1585 & 0.0856 & 0.0640 & -0.1207 & 0.0913 & 0.1860 & 0.0001 & 0.0796 & 0.9990 & -0.0364 & 0.0888 & 0.6820 & 0.0528 & 0.1162 & 0.6500 \\
\hline edu_2 & -0.0208 & 0.0704 & 0.7670 & -0.0756 & 0.0763 & 0.3220 & -0.0308 & 0.0653 & 0.6380 & -0.0700 & 0.0725 & 0.3350 & -0.0469 & 0.0927 & 0.6130 \\
\hline edu_3 & -0.1071 & 0.0670 & 0.1100 & -0.1497 & 0.0727 & 0.0390 & -0.1027 & 0.0630 & 0.1030 & -0.0850 & 0.0697 & 0.2230 & -0.1094 & 0.0898 & 0.2230 \\
\hline edu_4 & -0.1203 & 0.0624 & 0.0540 & -0.1181 & 0.0684 & 0.0840 & -0.0587 & 0.0590 & 0.3200 & -0.0530 & 0.0654 & 0.4170 & -0.0122 & 0.0803 & 0.8800 \\
\hline empl_fulltime & -0.0727 & 0.0610 & 0.2330 & 0.0645 & 0.0676 & 0.3400 & -0.0441 & 0.0575 & 0.4440 & 0.1596 & 0.0636 & 0.0120 & 0.1278 & 0.0862 & 0.1380 \\
\hline empl_leave & 0.0285 & 0.1339 & 0.8310 & -0.0112 & 0.1376 & 0.9350 & 0.1397 & 0.1219 & 0.2520 & 0.1807 & 0.1321 & 0.1710 & 0.1599 & 0.1769 & 0.3660 \\
\hline empl_parttime & -0.1822 & 0.0735 & 0.0130 & 0.0876 & 0.0817 & 0.2840 & -0.0858 & 0.0707 & 0.2240 & 0.0864 & 0.0775 & 0.2650 & 0.2112 & 0.1028 & 0.0400 \\
\hline occup_executive & 0.0458 & 0.0722 & 0.5260 & 0.0704 & 0.0778 & 0.3660 & 0.2513 & 0.0685 & 0.0000 & 0.1486 & 0.0755 & 0.0490 & 0.3689 & 0.1018 & 0.0000 \\
\hline occup_professionals & 614 & 0.0741 & 0.4070 & -0.0045 & 0.0796 & 0.9550 & 0.1757 & 0.0711 & 0.0130 & 0.1224 & 0.0787 & 0.1200 & 0.2934 & 0.1049 & 0.0050 \\
\hline occup_salaried & -0.0128 & 0.0608 & 0.8330 & -0.0142 & 0.0646 & 0.8260 & 0.1117 & 0.0582 & 0.0550 & 0.0598 & 0.0650 & 0.3580 & 0.0836 & 0.0912 & 0.3590 \\
\hline occup_selfemployed & 0.1489 & 0.0830 & 0.0730 & 0.0511 & 0.0895 & 0.5680 & 0.1709 & 0.0781 & 0.0290 & 0.1857 & 0.0853 & 0.0290 & 0.1519 & 0.1161 & 0.1910 \\
\hline type_house & 0.3062 & 0.0415 & 0.0000 & 0.2780 & 0.0439 & 0.0000 & 0.4751 & 0.0399 & 0.0000 & 0.4375 & 0.0442 & 0.0000 & 0.4291 & 0.0609 & 0.0000 \\
\hline area_urban & 0.0063 & 0.0457 & 0.8900 & -0.1131 & 0.0502 & 0.0240 & -0.1401 & 0.0430 & 0.0010 & -0.0907 & 0.0458 & 0.0480 & -0.2710 & 0.0573 & 0.0000 \\
\hline policy_TOU & 0.0528 & 0.0396 & 0.1830 & 0.0303 & 0.0424 & 0.4750 & 0.1034 & 0.0374 & 0.0060 & 0.1296 & 0.0410 & 0.0020 & 0.1926 & 0.0547 & 0.0000 \\
\hline _cons & 0.5300 & 0.1291 & 0.0000 & 0.4832 & 0.1357 & 0.0000 & -0.0848 & 0.1211 & 0.4840 & -0.6888 & 0.1318 & 0.0000 & -1.5691 & 0.1719 & 0.0000 \\
\hline
\end{tabular}

Notes:

1. empl_homemaker dropped because of collinearity

2. empl_retired dropped because of collinearity 
Table B3. rho values from multivariate binary probit model

\begin{tabular}{|c|c|c|c|c|c|c|}
\hline & Coef. & Std. Err. & $\mathbf{z}$ & $\mathbf{P}>\mathbf{Z}$ & \multicolumn{2}{|c|}{ [95\% Conf.Interval] } \\
\hline rho21 & 0.4054 & 0.0223 & 18.1500 & 0.0000 & 0.3607 & 0.4482 \\
\hline rho31 & 0.3902 & 0.0253 & 15.4100 & 0.0000 & 0.3395 & 0.4387 \\
\hline rho41 & 0.4284 & 0.0236 & 18.1200 & 0.0000 & 0.3809 & 0.4735 \\
\hline rho51 & 0.3112 & 0.0230 & 13.5100 & 0.0000 & 0.2654 & 0.3556 \\
\hline rho61 & 0.1231 & 0.0241 & 5.1000 & 0.0000 & 0.0755 & 0.1701 \\
\hline rho71 & 0.1408 & 0.0261 & 5.3900 & 0.0000 & 0.0893 & 0.1916 \\
\hline rho101 & -0.0991 & 0.0334 & -2.9700 & 0.0030 & -0.1639 & -0.0334 \\
\hline rho32 & 0.3893 & 0.0233 & 16.7000 & 0.0000 & 0.3427 & 0.4340 \\
\hline rho42 & 0.4006 & 0.0219 & 18.2900 & 0.0000 & 0.3568 & 0.4426 \\
\hline rho52 & 0.3245 & 0.0196 & 16.6000 & 0.0000 & 0.2857 & 0.3623 \\
\hline rho62 & 0.1140 & 0.0215 & 5.3100 & 0.0000 & 0.0717 & 0.1558 \\
\hline rho102 & -0.0436 & 0.0299 & -1.4600 & 0.1450 & -0.1019 & 0.0151 \\
\hline rho43 & 0.4057 & 0.0236 & 17.1900 & 0.0000 & 0.3584 & 0.4509 \\
\hline rho53 & 0.2705 & 0.0222 & 12.1700 & 0.0000 & 0.2265 & 0.3135 \\
\hline rho63 & 0.1690 & 0.0231 & 7.3100 & 0.0000 & 0.1234 & 0.2140 \\
\hline rho73 & 0.1653 & 0.0248 & 6.6700 & 0.0000 & 0.1164 & 0.2135 \\
\hline rho83 & 0.1129 & 0.0229 & 4.9400 & 0.0000 & 0.0679 & 0.1575 \\
\hline rho93 & 0.0711 & 0.0257 & 2.7600 & 0.0060 & 0.0205 & 0.1213 \\
\hline rho103 & -0.0543 & 0.0340 & -1.6000 & 0.1100 & -0.1206 & 0.0125 \\
\hline rho54 & 0.5715 & 0.0173 & 33.0400 & 0.0000 & 0.5367 & 0.6045 \\
\hline rho64 & 0.1455 & 0.0225 & 6.4600 & 0.0000 & 0.1011 & 0.1893 \\
\hline rho74 & 0.1444 & 0.0243 & 5.9500 & 0.0000 & 0.0965 & 0.1916 \\
\hline rho95 & 0.0962 & 0.0221 & 4.3600 & 0.0000 & 0.0528 & 0.1393 \\
\hline rho105 & 0.0822 & 0.0289 & 2.8400 & 0.0040 & 0.0253 & 0.1385 \\
\hline rho76 & 0.2453 & 0.0224 & 10.9300 & 0.0000 & 0.2009 & 0.2888 \\
\hline rho86 & 0.2937 & 0.0197 & 14.8800 & 0.0000 & 0.2545 & 0.3319 \\
\hline rho96 & 0.2592 & 0.0224 & 11.5600 & 0.0000 & 0.2148 & 0.3026 \\
\hline rho106 & 0.1349 & 0.0308 & 4.3800 & 0.0000 & 0.0740 & 0.1947 \\
\hline rho87 & 0.2363 & 0.0212 & 11.1600 & 0.0000 & 0.1944 & 0.2774 \\
\hline rho97 & 0.1659 & 0.0240 & 6.9100 & 0.0000 & 0.1185 & 0.2125 \\
\hline rho107 & 0.1117 & 0.0322 & 3.4700 & 0.0010 & 0.0483 & 0.1743 \\
\hline rho98 & 0.4067 & 0.0195 & 20.8200 & 0.0000 & 0.3677 & 0.4443 \\
\hline rho108 & 0.3633 & 0.0268 & 13.5300 & 0.0000 & 0.3096 & 0.4147 \\
\hline rho109 & 0.4437 & 0.0251 & 17.7100 & 0.0000 & 0.3933 & 0.4914 \\
\hline
\end{tabular}

Likelihood ratio test of rho2 $1=$ rho31 $=$ rho4 $1=$ rho5 $1=$ rho6 $1=$ rho71 $=$ rho81 $=$ rho91 $=$ rho101 $=$ rho32 $=\operatorname{rho} 42=\operatorname{rho5} 2=\operatorname{rho} 62=\operatorname{rho} 72=\operatorname{rho} 82=\operatorname{rho} 92=\operatorname{rho} 102=\operatorname{rho} 43=\operatorname{rho} 53=$ rho63 $=\operatorname{rho} 73=\operatorname{rho} 83=\operatorname{rho} 93=\operatorname{rho} 103=\operatorname{rho} 54=\operatorname{rho64}=\operatorname{rho} 74=\operatorname{rho} 84=\operatorname{rho} 94=\operatorname{rho} 104=$ rho65 $=\operatorname{rho} 75=\operatorname{rho} 85=\operatorname{rho} 95=\operatorname{rho} 105=\operatorname{rho} 76=\operatorname{rho} 86=\operatorname{rho} 96=\operatorname{rho} 106=\operatorname{rho} 87=\operatorname{rho} 97=$ rho107 $=$ rho9 $8=$ rho $108=$ rho109 $=0: \operatorname{chi} 2(45)=3455.87$ Prob $>$ chi $2=0.0000$ 
APPENDIX C: Results of univariate binary probit for energy efficient measures and investments

Table C1. Univariate binary probit estimation results for energy efficient measures.

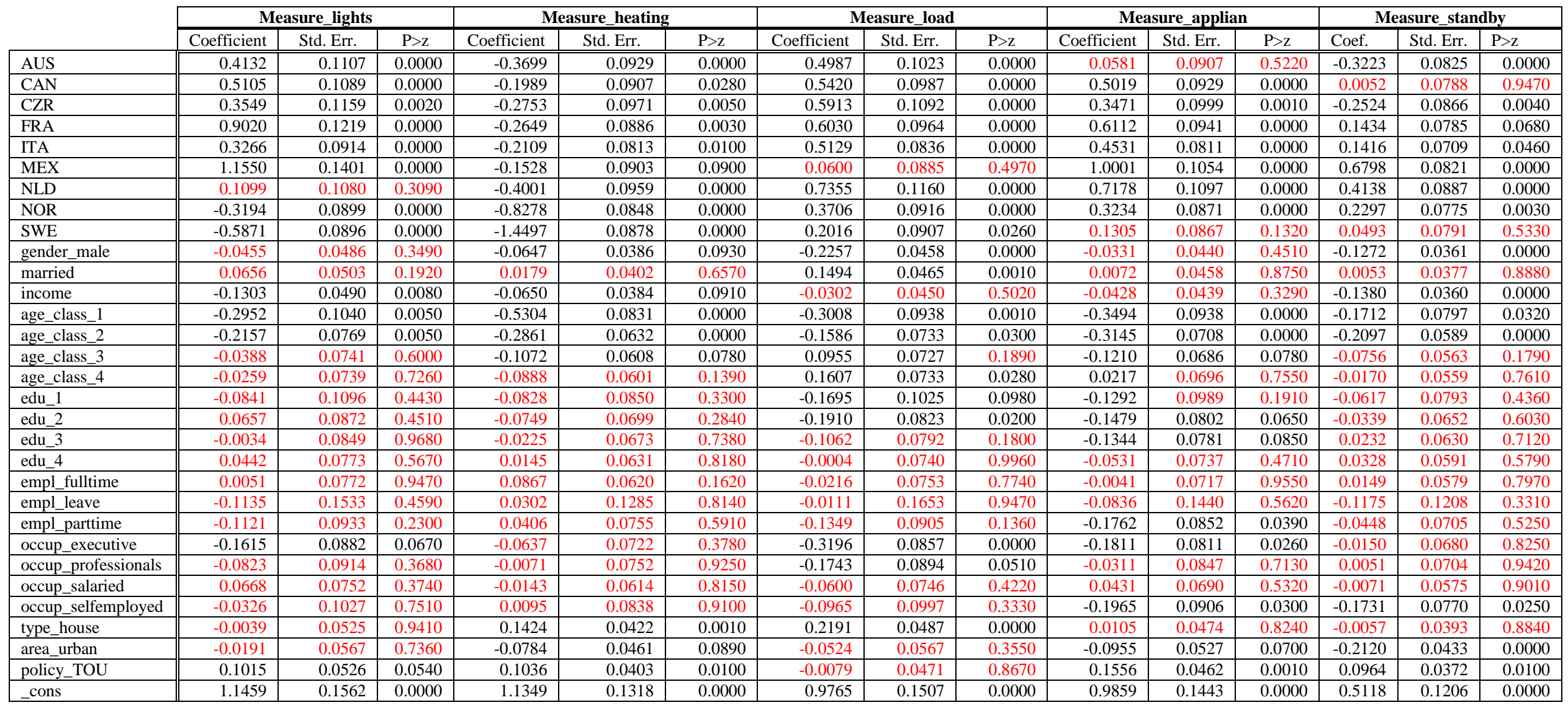

Notes:

1. empl_homemaker dropped because of collinearity

2. empl_retired dropped because of collinearity 
Table C2. Univariate binary probit estimation results for energy efficient investmetns.

\begin{tabular}{|c|c|c|c|c|c|c|c|c|c|c|c|c|c|c|c|}
\hline & \multicolumn{3}{|c|}{ Efficient_appliances } & \multicolumn{3}{|c|}{ Efficient_bulbs } & \multicolumn{3}{|c|}{ Efficient_insulation } & \multicolumn{3}{|c|}{ Efficient_heating } & \multicolumn{3}{|c|}{ Renewable_energy } \\
\hline & Coefficient & Std. Err. & $\mathrm{P}>\mathrm{Z}$ & Coefficient & Std. Err. & $\mathrm{P}>\mathrm{Z}$ & Coefficient & Std. Err. & $P>Z$ & Coefficient & Std. Err. & $\mathrm{P}>\mathrm{Z}$ & Coef. & Std. Err. & $\mathrm{P}>\mathrm{Z}$ \\
\hline AUS & $\begin{array}{c}-0.3811 \\
\end{array}$ & 0.0889 & "0.0000 & 0.2985 & 0.0902 & 0.0010 & $\begin{array}{c}-0.3123 \\
\end{array}$ & 0.0833 & "0.0000 & $\begin{array}{c}-0.4531 \\
\end{array}$ & 0.0873 & 0.0000 & $\begin{array}{l}-0.3990 \\
\end{array}$ & 0.1097 & 0.0000 \\
\hline CAN & -0.4404 & 0.0848 & 0.0000 & 0.5319 & 0.0889 & 0.0000 & -0.3906 & 0.0800 & 0.0000 & -0.3587 & 0.0832 & 0.0000 & -0.6713 & 0.1183 & 0.0000 \\
\hline CZR & 0.4244 & 0.1057 & 0.0000 & 0.7604 & 0.1028 & 0.0000 & 0.0162 & 0.0872 & 0.8530 & $\begin{array}{l}-0.8191 \\
\end{array}$ & 0.1021 & 0.0000 & -0.8186 & 0.1436 & 0.0000 \\
\hline FRA & 0.0286 & 0.0873 & 0.7430 & 0.1585 & 0.0834 & 0.0580 & -0.1087 & 0.0794 & 0.1710 & -0.5925 & 0.0854 & 0.0000 & -0.7659 & 0.1179 & 0.0000 \\
\hline ITA & -0.0717 & 0.0775 & 0.3550 & 0.7446 & 0.0796 & 0.0000 & -0.1638 & 0.0711 & 0.0210 & -0.4055 & 0.0758 & 0.0000 & -0.2136 & 0.0945 & 0.0240 \\
\hline MEX & -0.3520 & 0.0851 & 0.0000 & 0.6450 & 0.0892 & 0.0000 & -1.2039 & 0.0838 & 0.0000 & -1.5179 & 0.1029 & 0.0000 & -1.1359 & 0.1269 & 0.0000 \\
\hline NLD & -0.1397 & 0.0935 & 0.1350 & 0.1973 & 0.0914 & 0.0310 & 0.1495 & 0.0876 & 0.0880 & 0.6838 & 0.0889 & 0.0000 & $\begin{array}{l}-0.7079 \\
\end{array}$ & 0.1321 & 0.0000 \\
\hline NOR & -0.5294 & 0.0823 & 0.0000 & 0.3295 & 0.0837 & 0.0000 & $\begin{array}{l}-0.6213 \\
\end{array}$ & 0.0777 & 0.0000 & -0.6350 & 0.0837 & 0.0000 & 0.0223 & 0.0971 & 0.8190 \\
\hline SWE & -0.7540 & 0.0839 & 0.0000 & 0.2403 & 0.0842 & 0.0040 & -0.5907 & 0.0815 & 0.0000 & -0.3556 & 0.0856 & 0.0000 & -0.4803 & 0.1163 & 0.0000 \\
\hline gender_male & -0.0114 & 0.0379 & 0.7650 & -0.0243 & 0.0411 & 0.5540 & 0.0403 & 0.0364 & 0.2680 & 0.0022 & 0.0407 & 0.9570 & 0.1049 & 0.0542 & 0.0530 \\
\hline married & 0.2029 & 0.0391 & 0.0000 & 0.1487 & 0.0419 & 0.0000 & 0.1053 & 0.0381 & 0.0060 & -0.0144 & 0.0427 & 0.7350 & $\begin{array}{l}-0.0176 \\
\end{array}$ & 0.0570 & 0.7580 \\
\hline income & 0.0723 & 0.0380 & 0.0570 & 0.0612 & 0.0414 & 0.1400 & 0.1032 & 0.0362 & 0.0040 & 0.1011 & 0.0405 & 0.0130 & 0.0617 & 0.0532 & 0.2460 \\
\hline age_class_1 & -0.0899 & 0.0810 & 0.2670 & -0.3773 & 0.0874 & 0.0000 & -0.3285 & 0.0821 & 0.0000 & 0.0833 & 0.0877 & 0.3420 & 0.3723 & 0.1128 & 0.0010 \\
\hline age_class_2 & 0.1266 & 0.0619 & 0.0410 & -0.2726 & 0.0681 & 0.0000 & -0.1682 & 0.0592 & 0.0040 & $\begin{array}{l}-0.1038 \\
\end{array}$ & 0.0654 & 0.1130 & 0.1770 & 0.0859 & 0.0390 \\
\hline age_class_3 & 0.0639 & 0.0587 & 0.2770 & -0.1672 & 0.0660 & 0.0110 & -0.1129 & 0.0562 & 0.0450 & -0.1026 & 0.0618 & 0.0970 & 0.0009 & 0.0832 & 0.9910 \\
\hline age_class_4 & 0.1449 & 0.0589 & 0.0140 & $\begin{array}{l}-0.0977 \\
\end{array}$ & 0.0659 & 0.1390 & 0.0273 & 0.0557 & 0.6240 & $\begin{array}{l}-0.0758 \\
\end{array}$ & 0.0615 & 0.2180 & 0.0953 & 0.0815 & 0.2430 \\
\hline edu_1 & -0.1502 & 0.0859 & 0.0800 & -0.1160 & 0.0921 & 0.2080 & -0.0030 & 0.0802 & 0.9700 & -0.0440 & 0.0898 & 0.6240 & 0.0328 & 0.1189 & 0.7820 \\
\hline edu_2 & -0.0103 & 0.0706 & 0.8840 & -0.0702 & 0.0767 & 0.3600 & -0.0342 & 0.0657 & 0.6030 & -0.0689 & 0.0731 & 0.3460 & -0.0435 & 0.0939 & 0.6430 \\
\hline edu_3 & -0.0925 & 0.0670 & 0.1670 & -0.1408 & 0.0731 & 0.0540 & -0.0976 & 0.0634 & 0.1240 & -0.0833 & 0.0705 & 0.2370 & -0.1111 & 0.0915 & 0.2250 \\
\hline edu_4 & -0.1093 & 0.0623 & 0.0800 & -0.1053 & 0.0687 & 0.1250 & -0.0603 & 0.0592 & 0.3080 & -0.0506 & 0.0661 & 0.4440 & -0.0141 & 0.0818 & 0.8630 \\
\hline empl_fulltime & -0.0758 & 0.0613 & 0.2160 & 0.0585 & 0.0681 & 0.3900 & -0.0479 & 0.0580 & 0.4090 & 0.1661 & 0.0645 & 0.0100 & 0.1149 & 0.0886 & 0.1950 \\
\hline empl_leave & 0.0257 & 0.1340 & 0.8480 & -0.0137 & 0.1382 & 0.9210 & 0.1299 & 0.1229 & 0.2900 & 0.1840 & 0.1348 & 0.1720 & 0.1308 & 0.1842 & 0.4780 \\
\hline empl_parttime & -0.1861 & 0.0736 & 0.0110 & 0.0760 & 0.0821 & 0.3540 & $\begin{array}{l}-0.0910 \\
\end{array}$ & 0.0711 & 0.2000 & 0.1032 & 0.0783 & 0.1880 & 0.2270 & 0.1051 & 0.0310 \\
\hline occup_executive & 0.0535 & 0.0723 & 0.4600 & 0.0675 & 0.0779 & 0.3860 & 0.2515 & 0.0688 & 0.0000 & 0.1357 & 0.0762 & 0.0750 & 0.3554 & 0.1038 & 0.0010 \\
\hline occup_professionals & 0.0650 & 0.0743 & 0.3820 & -0.0087 & 0.0800 & 0.9140 & 0.1750 & 0.0714 & 0.0140 & 0.1208 & 0.0794 & 0.1280 & 0.2830 & 0.1067 & 0.0080 \\
\hline occup_salaried & -0.0066 & 0.0610 & 0.9140 & $\begin{array}{l}-0.0078 \\
\end{array}$ & 0.0649 & 0.9040 & 0.1151 & 0.0585 & 0.0490 & 0.0591 & 0.0653 & 0.3650 & 0.0716 & 0.0926 & 0.4390 \\
\hline occup_selfemployed & 0.1458 & 0.0833 & 0.0800 & 0.0546 & 0.0904 & 0.5450 & 0.1672 & 0.0787 & 0.0340 & 0.1827 & 0.0858 & 0.0330 & 0.1523 & 0.1178 & 0.1960 \\
\hline type_house & 0.3104 & 0.0417 & 0.0000 & 0.2757 & 0.0441 & 0.0000 & 0.4725 & 0.0401 & 0.0000 & 0.4200 & 0.0444 & 0.0000 & 0.3812 & 0.0611 & 0.0000 \\
\hline area_urban & 0.0045 & 0.0459 & 0.9220 & -0.1175 & 0.0504 & 0.0200 & $\begin{array}{l}-0.1470 \\
\end{array}$ & 0.0433 & 0.0010 & $\begin{array}{l}-0.0963 \\
\end{array}$ & 0.0464 & 0.0380 & -0.2557 & 0.0588 & 0.0000 \\
\hline policy_TOU & 0.0519 & 0.0397 & 0.1910 & 0.0287 & 0.0426 & 0.5000 & 0.1027 & 0.0376 & 0.0060 & 0.1464 & 0.0413 & 0.0000 & 0.2175 & 0.0555 & 0.0000 \\
\hline _cons & 0.5143 & 0.1288 & 0.0000 & 0.4789 & 0.1360 & 0.0000 & -0.0672 & 0.1213 & 0.5790 & -0.6746 & 0.1328 & 0.0000 & -1.5476 & 0.1751 & 0.0000 \\
\hline
\end{tabular}

Notes:

1. empl_homemaker dropped because of collinearity

2. empl_retired dropped because of collinearity 


\section{APPENDIX D: Alternative analysis}

\section{D.1. Multivariate and Univariate Probit Evaluation of the Effects of Individual, Household and Policy Variable on Measures and Investments}

The results from the multivariate and univariate binary probit estimation are provided Table D1 to D5. The multivariate probit provides a good estimate for this model - there is evidence of relation between the measures and investments activities considered in this paper. The hypothesis that the 45 off-diagonal coefficients of the variance-covariance matrix are equal to 0 is rejected, with chi2(45)=1547.31, at less than $1 \%$ (Table D3). This explains the slight differences in the coefficients obtained from multivariate and univariate probit model; however, the effect of the variables on measures and investments is generally consistent, with the following discrepancies:

(a) A negative effect is observed for multivariate probit on the effect that being on leave (Empl_leave) has on the likelihood of turning the lights off when not in use (Measure_lights) and installing renewable energy equipment (Renewable_energy), whereas a positive effect is observed when using the univariate probit model. The same inconsistency is observed for the effect that being from country Mexico has on the likelihood of cutting down on heating or air conditioning (Measure_heating). On the other hand, being self-employed (Occup_selfemployed) is shown to have a positive effect on renewable energy using univariate probit and a negative effect using multivariate probit. A similar inconsistency is observed for the effects of working part-time (Empl_parttime) on the likelihood of turning appliances to standby when not in use (Measure_standby), and in the effects of being self-employed (Occup_selfemployed) on 
the installation of renewable energy equipment (Renewable_energy). Nevertheless, all these coefficients are insignificant and do not pose a concern for this analysis.

(b) Another difference observed between the multivariate probit and univariate probit results, is the significance of results under one of the models and insignificance in the other. For example, the effect of being between 45 and 54 years old (Age_class_4) on the likelihood of turning appliances to standby when not in use (Measure_standby) is insignificant under the multivariate probit model, but significant under the univariate probit. This demonstrates that this variable alone does not impact the specific decision to partake in this measure. The same discrepancy is observed on the effect that being male (Gender_male) has on the likelihood of turning off appliances when not in use (Measure_appliances), and the effects of having income higher than $\$ 54,700$ a year (Income) has on the likelihood of installing efficient heating boiler. Moreover, we observe that being self-employed (Occup_selfeployed) has a significant effect on the likelihood of installing efficient light bulbs (Efficient_bulbs) under the multivariate probit and an insignificant effect when using the univariate probit model. The same is observed for the effects of living in an urban area (Area_urban) on the likelihood of a household waiting for a full-load before using the washing machine (Measure_full_load).

Moreover, being a homemaker (Empl_homemaker), being on leave (Empl_leave), being a manual worker (Occup_manualworker) were dropped due to colinearity of results. The following sections describe the effects of individual, household and altitudinal factors on energy saving measures and investments and renewable energy implementation, considering only statistically significant results. 


\section{D.2. Country Specific Characteristics}

Households in Korea are more likely to turn the lights off when leaving the room (Measure_lights) more than households in Sweden and Norway, but less likely than in any other participating country. In addition, households in Korea are more likely to cut down on heating/AC (Measure_heating) as an energy saving measure than are households in Sweden and Norway, but less likely to wait for a full load before using the washer/dryer (Measure_full_load) and turn-off appliances when not in use (Measure_appliances) than any other participating country. Turning the appliances to standby when not in use (Measure_standby) is a measure more likely to be implemented in Netherlands, Mexico, Italy and Norway.

Country specific effects are also observed in the level of energy saving investments. We observe that households in Czech Republic are more likely to invest in energy efficient appliances (Efficient_appliances) than households in Korea; countries such as Canada, Mexico, Sweden, Norway, and Australia are less likely to do so. Furthermore, the use of energy efficient bulbs (Efficient_bulbs) is less likely to be employed in households in Korea than households in any other participating country. These results are supported by the analysis of the OECD (2011) study. Thermal insulation (Efficient_insulation) and installation of efficient heating boiler (Efficient_heating) are investments more likely to be implemented in households in Netherlands than in Korea and any other country; all other participating countries are less likely to partake in these investments. Moreover, installation of renewable energy equipment (Renewable_energy) is more likely to occur in households in Korea. It is interesting to note that while all coefficient values are negative for the renewable energy variable, there are significant differences between countries. For example, Mexico (coefficient of -1.0811) is less likely than all other countries to install renewable energy equipment. To summarize, there is evidence suggesting that there are 
country specific factors that affect the level of households partaking in energy saving measures and investments. This could be due to many different factors such as cultural and educational factors, policy, energy prices, or weather conditions; however the exact cause of these differences is difficult to determine without further evidence.

\section{D.3. Individual and Household Characteristics}

Male participants are less likely than females to turn off lights when leaving the room (Measure_lights), wait for a full load before using the washer/dryer (Measure_full_load), and turn the appliances to standby when not in use (Measure_standby). Generally, being married or living as a couple has a positive effect on the adaptation of energy conserving measures and investments. Participants that were married or living as a couple were more likely to turn the lights off when leaving the room (Measure_lights), cut down on heating/AC (Measure_heating), wait for a full load before using the washer/dryer (Measure_full_load), invest in energy efficient appliances (Efficient_appliances), use of energy efficient bulbs (Efficient_bulbs). We also observe participants between ages 45 and 54 (Age_class_4) are more likely to turn off appliances when not in use (Measure_appliances), wait for a full load before using washing machine/dishwasher (Measure_full_load), invest in energy efficient appliances (Efficient_appliances) and thermal insulation (Efficient_insulation).

Having a household income higher than $\$ 54,700$ negatively influences the likelihood of a household to turn off lights when leaving the room (Measure_lights), and turning the appliances to standby when not in use (Measure_standby); however a positive effect is observed on installation of thermal insulation (Efficient_insulation). Looking at the coefficient, including the statistically insignificant ones, we observe that generally higher incomes would allow people to invest on energy saving measures, while low incomes would sway households towards more 
simple energy saving measures. Employment (full-time, part-time, or on leave) is generally insignificant across the equations. We observe that being employed full-time has a negative effect on the likelihood of turning-off appliances when not in use (Measure_appliances), and investing in energy efficient appliances (Efficient_insulation). Being employed part-time has a negative effect on the likelihood of households turning-off lights when leaving the room (Measure_lights), investing in energy efficient appliances (Efficient_insulation) and positive on installation of renewable energy equipment (Renewable_energy). Moreover, being on leave has a positive effect on a household investing in energy efficient appliances (Efficient_appliances). As we can see these results do not exhibit a specific pattern making it difficult to infer behaviour. On the other hand, occupation, whether being a professional, executive or self-employed has a negative impact on energy saving measures and a positive effect on energy saving investments. Specifically, professionals are less likely to wait for a full load before using the washing machine or dishwasher (Measure_full_load) and more likely to invest in efficient appliances (Efficient_appliances), thermal insulation (Efficient_insulation), efficient heating (Efficient_heating), and renewable energy (Renewable_energy). Executives are less likely to turn-off lights when leaving the room (Measure_lights), waiting for a full load before using the washing machine or dishwasher (Measure_full_load), and turning-off appliances when not in use (Measure_appliances), but more likely to invest in efficient light bulbs (Efficient_bulbs), thermal insulation (Efficient_insulation), efficient heating (Efficient_heating), and renewable energy (Renewable_energy). Likewise, self-employed participants are less likely to turn-off appliances when not in use (Measure_appliances) and more likely to invest in thermal insulation (Efficient_insulation). 
Residence and household location coefficients are mainly statistically insignificant and do not exhibit a specific pattern; nevertheless the findings of statistically significant effects are worth noting. Participants living in a house are more likely to wait for a full load before using the washer/dryer (Measure_full_load), and more likely to invest in all five investment types. Households in rural areas are more likely to turn-off appliances (Measure_appliances) and switch equipment to standby mode when not in use (Measure_standby); while households in urban areas are less likely to invest in renewable energy (Renewable_energy).

\section{D.4. Time-of-Use Policy}

The effects of varying electricity pricing (Policy_timeofuse) are statistically insignificant in five of the equations, and it can be inferred that TOU policy does not impact these decisions. In the statistically significant equations, varying electricity prices encourage energy saving measures and investments. This analysis shows that having varying electricity pricing increases the likelihood of a household investing in thermal insulation (Efficient_insulation), efficient heating boiler (Efficient_heating), and renewable energy (Renewable_energy). Moreover, we observe that TOU pricing has a positive impact on participants turning-off appliances (Measure_appliances) and switching equipment to standby mode when not in use (Measure_standby). 


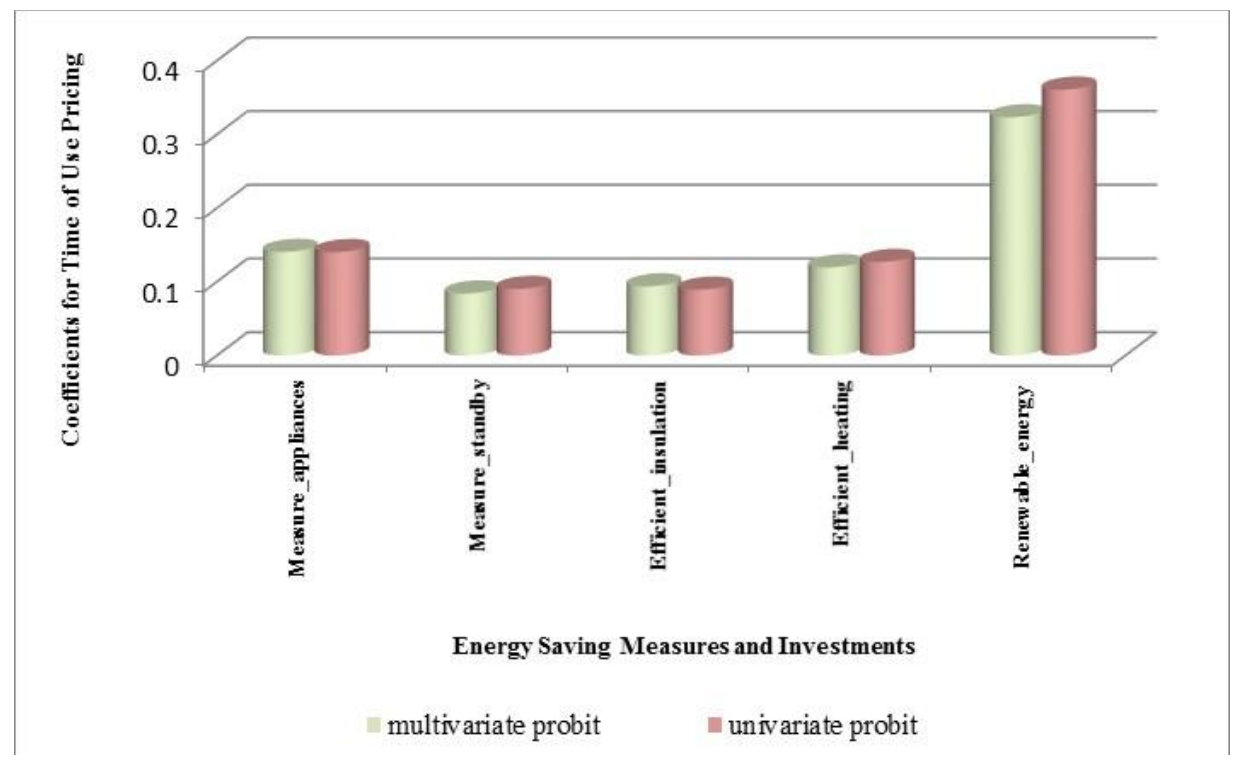

Figure D1. Effects of varying electricity pricing on energy saving measures and investments using the multivariate and univariate probit model. 
Table D1. Multivariate binary probit estimation results for energy efficient measures for alternative analysis. Statistically insignificant results are marked in red.

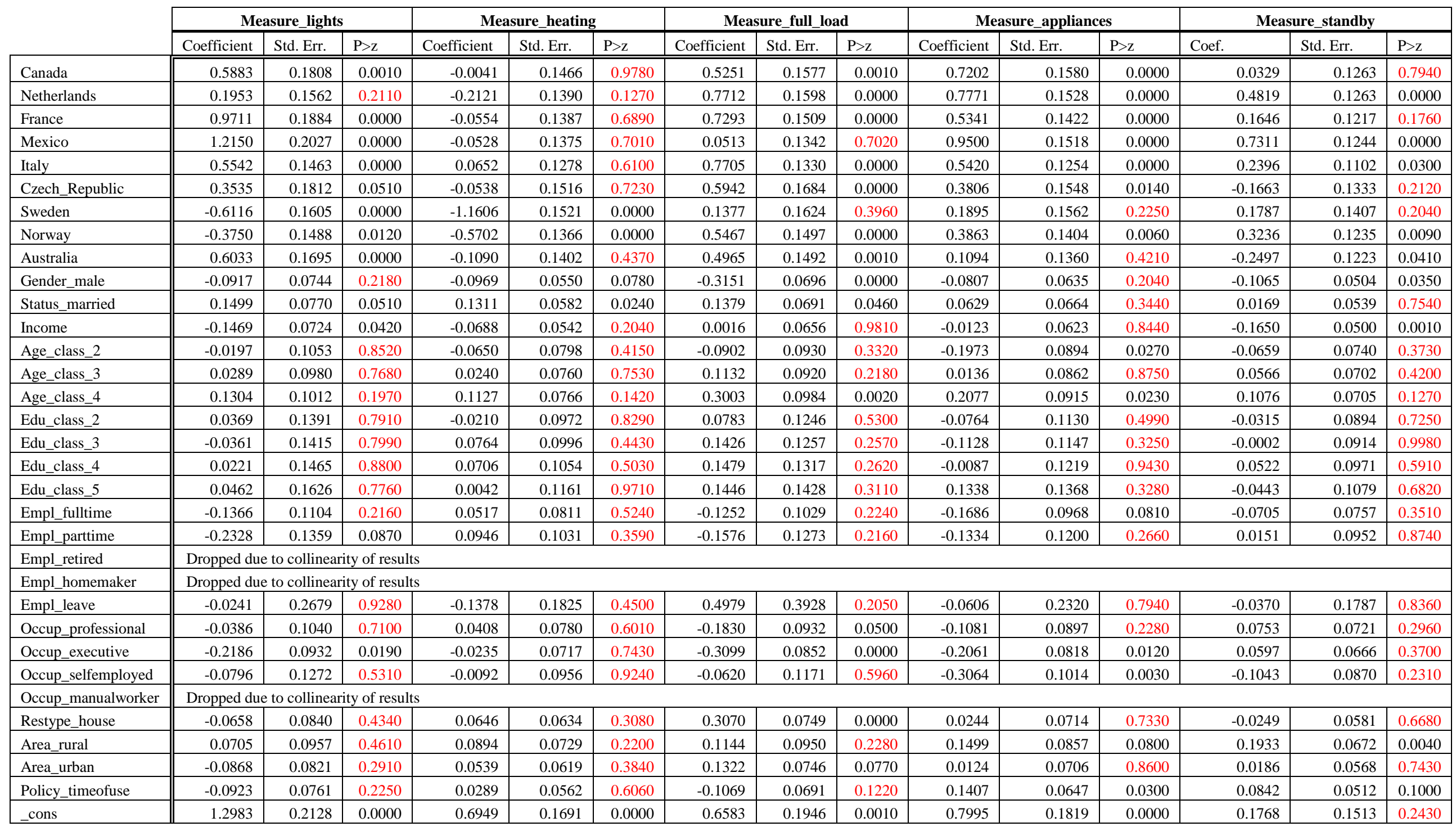


Table D2. Multivariate binary probit estimation results for energy efficient investments for alternative analysis. Statistically insignificant results are marked in red.

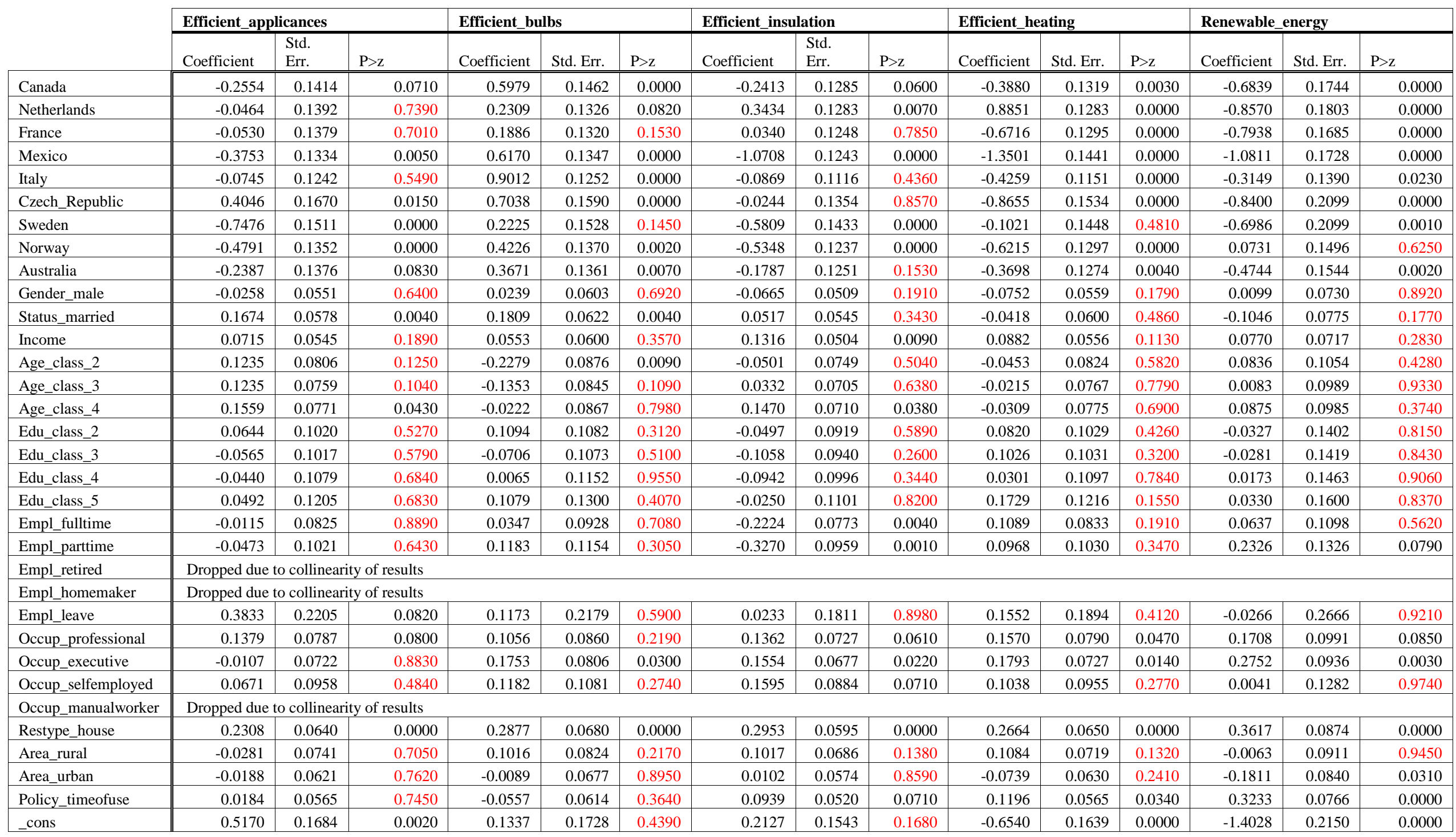


Table D3. rho values from multivariate binary probit model for alternative analysis.

\begin{tabular}{|c|c|c|c|c|c|c|c|c|c|c|c|c|c|}
\hline & Coefficient & Std. Err. & $\mathbf{z}$ & $\mathbf{P}>\mathbf{z}$ & {$[95 \%$ Cor } & terval] & & Coefficient & Std. Err. & $\mathbf{z}$ & $\mathbf{P}>\mathbf{Z}$ & {$[95 \%$ Con } & terval] \\
\hline rho21 & 0.4426 & 0.0327 & 13.5500 & 0.0000 & 0.3764 & 0.5043 & rho103 & 0.0182 & 0.0482 & 0.3800 & 0.7060 & -0.0762 & 0.1122 \\
\hline rho31 & 0.4210 & 0.0375 & 11.2200 & 0.0000 & 0.3448 & 0.4918 & rho54 & 0.5259 & 0.0270 & 19.4600 & 0.0000 & 0.4709 & 0.5768 \\
\hline rho41 & 0.4227 & 0.0337 & 12.5600 & 0.0000 & 0.3546 & 0.4863 & rho64 & 0.1720 & 0.0332 & 5.1800 & 0.0000 & 0.1062 & 0.2363 \\
\hline rho51 & 0.3331 & 0.0324 & 10.2900 & 0.0000 & 0.2682 & 0.3950 & rho74 & 0.1579 & 0.0356 & 4.4300 & 0.0000 & 0.0873 & 0.2268 \\
\hline rho61 & 0.1598 & 0.0357 & 4.4700 & 0.0000 & 0.0891 & 0.2290 & rho84 & 0.1325 & 0.0316 & 4.1900 & 0.0000 & 0.0701 & 0.1938 \\
\hline rho71 & 0.0534 & 0.0392 & 1.3600 & 0.1730 & -0.0236 & 0.1298 & rho94 & -0.0083 & 0.0355 & -0.2300 & 0.8150 & -0.0778 & 0.0612 \\
\hline rho81 & 0.1027 & 0.0344 & 2.9900 & 0.0030 & 0.0350 & 0.1696 & rho104 & -0.0354 & 0.0450 & -0.7900 & 0.4310 & -0.1232 & 0.0529 \\
\hline rho91 & -0.0102 & 0.0369 & -0.2800 & 0.7820 & -0.0823 & 0.0620 & rho65 & 0.0846 & 0.0304 & 2.7800 & 0.0050 & 0.0247 & 0.1439 \\
\hline rho101 & -0.0608 & 0.0461 & -1.3200 & 0.1870 & -0.1503 & 0.0297 & rho75 & 0.1631 & 0.0331 & 4.9300 & 0.0000 & 0.0977 & 0.2271 \\
\hline rho32 & 0.4010 & 0.0341 & 11.7500 & 0.0000 & 0.3320 & 0.4657 & rho85 & 0.1080 & 0.0280 & 3.8500 & 0.0000 & 0.0528 & 0.1626 \\
\hline rho42 & 0.4481 & 0.0311 & 14.4000 & 0.0000 & 0.3851 & 0.5070 & rho95 & 0.0754 & 0.0310 & 2.4300 & 0.0150 & 0.0143 & 0.1358 \\
\hline rho52 & 0.3521 & 0.0275 & 12.8200 & 0.0000 & 0.2972 & 0.4047 & rho105 & 0.0748 & 0.0403 & 1.8500 & 0.0640 & -0.0046 & 0.1532 \\
\hline rho62 & 0.1317 & 0.0312 & 4.2300 & 0.0000 & 0.0702 & 0.1922 & rho76 & 0.1779 & 0.0339 & 5.2500 & 0.0000 & 0.1108 & 0.2434 \\
\hline rho72 & 0.0788 & 0.0343 & 2.3000 & 0.0220 & 0.0113 & 0.1457 & rho86 & 0.3050 & 0.0276 & 11.0400 & 0.0000 & 0.2499 & 0.3581 \\
\hline rho82 & 0.1509 & 0.0293 & 5.1500 & 0.0000 & 0.0930 & 0.2078 & rho96 & 0.2658 & 0.0315 & 8.4300 & 0.0000 & 0.2030 & 0.3264 \\
\hline rho92 & 0.0556 & 0.0319 & 1.7400 & 0.0820 & -0.0071 & 0.1179 & rho106 & 0.1503 & 0.0434 & 3.4700 & 0.0010 & 0.0644 & 0.2339 \\
\hline rho102 & -0.0086 & 0.0407 & -0.2100 & 0.8340 & -0.0882 & 0.0712 & rho87 & 0.2489 & 0.0311 & 8.0000 & 0.0000 & 0.1870 & 0.3088 \\
\hline rho43 & 0.4184 & 0.0352 & 11.8900 & 0.0000 & 0.3471 & 0.4849 & rho97 & 0.1683 & 0.0347 & 4.8500 & 0.0000 & 0.0996 & 0.2354 \\
\hline rho53 & 0.2513 & 0.0332 & 7.5700 & 0.0000 & 0.1852 & 0.3152 & rho107 & 0.1421 & 0.0454 & 3.1300 & 0.0020 & 0.0523 & 0.2296 \\
\hline rho63 & 0.1552 & 0.0352 & 4.4100 & 0.0000 & 0.0856 & 0.2233 & rho98 & 0.3591 & 0.0284 & 12.6600 & 0.0000 & 0.3023 & 0.4134 \\
\hline rho73 & 0.0783 & 0.0381 & 2.0500 & 0.0400 & 0.0033 & 0.1524 & rho108 & 0.3126 & 0.0379 & 8.2500 & 0.0000 & 0.2365 & 0.3849 \\
\hline rho83 & 0.1637 & 0.0333 & 4.9100 & 0.0000 & 0.0977 & 0.2282 & rho109 & 0.3756 & 0.0363 & 10.3500 & 0.0000 & 0.3024 & 0.4444 \\
\hline rho93 & 0.0558 & 0.0364 & 1.5300 & 0.1250 & -0.0157 & 0.1268 & & & & & & & \\
\hline
\end{tabular}

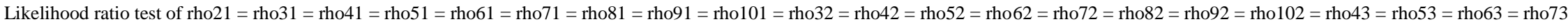
$=\operatorname{rho} 83=\operatorname{rho} 93=\operatorname{rho} 103=\operatorname{rho} 54=\operatorname{rho} 64=\operatorname{rho} 74=\operatorname{rho} 84=\operatorname{rho} 94=\operatorname{rho} 104=\operatorname{rho} 65=\operatorname{rho} 75=\operatorname{rho} 85=\operatorname{rho} 95=\operatorname{rho} 105=\operatorname{rho} 76=\operatorname{rho} 86=\operatorname{rho} 96=\operatorname{rho} 106=\operatorname{rho} 87=\operatorname{rho} 97=\operatorname{rho} 107=\operatorname{rho} 98=\operatorname{rho} 108$ $=$ rho109 $=0$ : $\operatorname{chi} 2(45)=1547.31$ Prob $>$ chi $2=0.0000$ 
Table D4. Univariate binary probit estimation results for energy efficient measures for alternative analysis. Statistically insignificant results are marked in red.

\begin{tabular}{|c|c|c|c|c|c|c|c|c|c|c|c|c|c|c|c|}
\hline & \multicolumn{3}{|c|}{ Measure_lights } & \multicolumn{3}{|c|}{ Measure_heating } & \multicolumn{3}{|c|}{ Measure_full_load } & \multicolumn{3}{|c|}{ Measure_appliances } & \multicolumn{3}{|c|}{ Measure_standby } \\
\hline & Coefficient & Std. Err. & $\mathrm{P}>\mathrm{Z}$ & Coefficient & Std. Err. & $\mathrm{P}>\mathrm{Z}$ & Coefficient & Std. Err. & $\mathrm{P}>\mathrm{z}$ & Coefficient & Std. Err. & $\mathrm{P}>\mathrm{z}$ & Coef. & Std. Err. & $\mathrm{P}>\mathrm{Z}$ \\
\hline Canada & 0.6651 & 0.1793 & 0.0000 & 0.0444 & 0.1452 & 0.7600 & 0.5325 & 0.1593 & 0.0010 & 0.7603 & 0.1593 & 0.0000 & 0.0290 & 0.1271 & 0.8200 \\
\hline Netherlands & 0.2592 & 0.1551 & 0.0950 & -0.1905 & 0.1375 & 0.1660 & 0.7821 & 0.1627 & 0.0000 & 0.7866 & 0.1543 & 0.0000 & 0.4515 & 0.1270 & 0.0000 \\
\hline France & 0.9910 & 0.1866 & 0.0000 & -0.0224 & 0.1371 & 0.8700 & 0.7348 & 0.1533 & 0.0000 & 0.5380 & 0.1436 & 0.0000 & 0.1466 & 0.1223 & 0.2310 \\
\hline Mexico & 1.3339 & 0.2061 & 0.0000 & 0.0187 & 0.1362 & 0.8910 & 0.0894 & 0.1355 & 0.5100 & 1.0292 & 0.1560 & 0.0000 & 0.7481 & 0.1257 & 0.0000 \\
\hline Italy & 0.5816 & 0.1427 & 0.0000 & 0.0928 & 0.1252 & 0.4580 & 0.7507 & 0.1325 & 0.0000 & 0.5519 & 0.1252 & 0.0000 & 0.2249 & 0.1104 & 0.0420 \\
\hline Czech_Republic & 0.4338 & 0.1817 & 0.0170 & -0.0214 & 0.1509 & 0.8870 & 0.6214 & 0.1711 & 0.0000 & 0.3917 & 0.1568 & 0.0130 & -0.1908 & 0.1341 & 0.1550 \\
\hline Sweden & -0.5598 & 0.1578 & 0.0000 & -1.1188 & 0.1501 & 0.0000 & 0.1112 & 0.1617 & 0.4920 & 0.2045 & 0.1567 & 0.1920 & 0.1726 & 0.1410 & 0.2210 \\
\hline Norway & -0.3280 & 0.1452 & 0.0240 & -0.5384 & 0.1338 & 0.0000 & 0.5087 & 0.1491 & 0.0010 & 0.3589 & 0.1393 & 0.0100 & 0.3065 & 0.1235 & 0.0130 \\
\hline Australia & 0.6434 & 0.1666 & 0.0000 & -0.0858 & 0.1379 & 0.5340 & 0.5032 & 0.1504 & 0.0010 & 0.1286 & 0.1367 & 0.3470 & -0.2738 & 0.1231 & 0.0260 \\
\hline Gender_male & -0.1178 & 0.0752 & 0.1170 & -0.1009 & 0.0558 & 0.0700 & -0.3154 & 0.0708 & 0.0000 & -0.1103 & 0.0652 & 0.0900 & -0.1263 & 0.0515 & 0.0140 \\
\hline Status_married & 0.1770 & 0.0771 & 0.0220 & 0.1482 & 0.0587 & 0.0120 & 0.1858 & 0.0698 & 0.0080 & 0.1066 & 0.0678 & 0.1160 & 0.0307 & 0.0550 & 0.5760 \\
\hline Income & -0.1674 & 0.0733 & 0.0220 & -0.0846 & 0.0550 & 0.1240 & -0.0122 & 0.0668 & 0.8560 & -0.0296 & 0.0638 & 0.6430 & -0.1758 & 0.0509 & 0.0010 \\
\hline Age_class_2 & -0.0621 & 0.1045 & 0.5530 & -0.0595 & 0.0805 & 0.4600 & -0.0804 & 0.0940 & 0.3920 & -0.1857 & 0.0908 & 0.0410 & -0.0306 & 0.0754 & 0.6850 \\
\hline Age_class_3 & 0.0485 & 0.0992 & 0.6250 & 0.0326 & 0.0769 & 0.6720 & 0.1314 & 0.0936 & 0.1600 & 0.0145 & 0.0881 & 0.8690 & 0.0630 & 0.0715 & 0.3780 \\
\hline Age_class_4 & 0.1568 & 0.1029 & 0.1280 & 0.1332 & 0.0778 & 0.0870 & 0.3285 & 0.1006 & 0.0010 & 0.2204 & 0.0935 & 0.0180 & 0.1239 & 0.0718 & 0.0850 \\
\hline Edu_class_2 & -0.0350 & 0.1452 & 0.8100 & -0.0455 & 0.0998 & 0.6480 & 0.0169 & 0.1291 & 0.8960 & -0.1191 & 0.1184 & 0.3140 & -0.0519 & 0.0917 & 0.5720 \\
\hline Edu_class_3 & -0.0887 & 0.1469 & 0.5460 & 0.0666 & 0.1018 & 0.5130 & 0.1045 & 0.1303 & 0.4220 & -0.1518 & 0.1200 & 0.2060 & -0.0081 & 0.0934 & 0.9310 \\
\hline Edu_class_4 & -0.0156 & 0.1523 & 0.9180 & 0.0633 & 0.1080 & 0.5580 & 0.1190 & 0.1364 & 0.3830 & -0.0349 & 0.1277 & 0.7850 & 0.0230 & 0.0994 & 0.8170 \\
\hline Edu_class_5 & 0.0162 & 0.1689 & 0.9240 & -0.0105 & 0.1187 & 0.9300 & 0.1114 & 0.1478 & 0.4510 & 0.1186 & 0.1431 & 0.4070 & -0.0492 & 0.1101 & 0.6550 \\
\hline Empl_fulltime & -0.1475 & 0.1118 & 0.1870 & 0.0391 & 0.0824 & 0.6350 & -0.1346 & 0.1047 & 0.1980 & -0.1897 & 0.0990 & 0.0550 & -0.0928 & 0.0772 & 0.2290 \\
\hline Empl_parttime & -0.2770 & 0.1364 & 0.0420 & 0.0555 & 0.1040 & 0.5940 & -0.1884 & 0.1289 & 0.1440 & -0.1646 & 0.1224 & 0.1790 & -0.0295 & 0.0965 & 0.7600 \\
\hline Empl_retired & \multicolumn{15}{|c|}{ Dropped due to collinearity of results } \\
\hline Empl_homemaker & \multicolumn{15}{|c|}{ Dropped due to collinearity of results } \\
\hline Empl_leave & 0.0710 & 0.2806 & 0.8000 & -0.1210 & 0.1866 & 0.5170 & 0.6175 & 0.4184 & 0.1400 & -0.0413 & 0.2429 & 0.8650 & -0.0431 & 0.1802 & 0.8110 \\
\hline Occup_professional & -0.0683 & 0.1057 & 0.5180 & 0.0327 & 0.0788 & 0.6780 & -0.1873 & 0.0949 & 0.0480 & -0.1071 & 0.0918 & 0.2440 & 0.0642 & 0.0736 & 0.3830 \\
\hline Occup_executive & -0.2590 & 0.0937 & 0.0060 & -0.0386 & 0.0725 & 0.5950 & -0.3441 & 0.0866 & 0.0000 & -0.2291 & 0.0832 & 0.0060 & 0.0453 & 0.0676 & 0.5020 \\
\hline Occup_selfemployed & -0.1223 & 0.1265 & 0.3340 & -0.0132 & 0.0968 & 0.8910 & -0.0851 & 0.1196 & 0.4770 & -0.3200 & 0.1043 & 0.0020 & -0.0966 & 0.0881 & 0.2730 \\
\hline Occup_salaried & \multicolumn{15}{|c|}{ Dropped due to collinearity of results } \\
\hline Restype_house & -0.0968 & 0.0842 & 0.2510 & 0.0544 & 0.0642 & 0.3970 & 0.3002 & 0.0759 & 0.0000 & 0.0261 & 0.0729 & 0.7200 & -0.0114 & 0.0591 & 0.8470 \\
\hline Area_rural & 0.0564 & 0.0971 & 0.5620 & 0.0994 & 0.0741 & 0.1800 & 0.1115 & 0.0966 & 0.2480 & 0.1477 & 0.0876 & 0.0920 & 0.1947 & 0.0687 & 0.0050 \\
\hline Area_urban & -0.1041 & 0.0824 & 0.2060 & 0.0505 & 0.0624 & 0.4180 & 0.1063 & 0.0756 & 0.1600 & 0.0003 & 0.0718 & 0.9970 & 0.0145 & 0.0577 & 0.8010 \\
\hline Policy_timeofuse & -0.0651 & 0.0762 & 0.3930 & 0.0361 & 0.0568 & 0.5250 & -0.1031 & 0.0702 & 0.1420 & 0.1404 & 0.0661 & 0.0340 & 0.0904 & 0.0521 & 0.0830 \\
\hline _cons & 1.3541 & 0.2157 & 0.0000 & 0.6922 & 0.1688 & 0.0000 & 0.7038 & 0.1980 & 0.0000 & 0.8486 & 0.1864 & 0.0000 & 0.2210 & 0.1530 & 0.1490 \\
\hline
\end{tabular}


Table D5. Univariate binary probit estimation results for energy efficient investments for alternative analysis. Statistically insignificant results are marked in red.

\begin{tabular}{|c|c|c|c|c|c|c|c|c|c|c|c|c|c|c|c|}
\hline & \multicolumn{3}{|c|}{ Efficient_appliances } & \multicolumn{3}{|c|}{ Efficient_bulbs } & \multicolumn{3}{|c|}{ Efficient_insulation } & \multicolumn{3}{|c|}{ Efficient_heating } & \multicolumn{3}{|c|}{ Renewable_energy } \\
\hline & Coefficient & Std. Err. & $\mathrm{P}>\mathrm{Z}$ & Coefficient & Std. Err. & $\mathrm{P}>\mathrm{z}$ & Coefficient & Std. Err. & $\mathrm{P}>\mathrm{z}$ & Coefficient & Std. Err. & $\mathrm{P}>\mathrm{z}$ & Coefficient & Std. Err. & $\mathrm{P}>\mathrm{z}$ \\
\hline Canada & -0.2302 & 0.1415 & 0.1040 & 0.6150 & 0.1466 & 0.0000 & -0.2502 & 0.1287 & 0.0520 & $\begin{array}{l}-0.3911 \\
\end{array}$ & 0.1323 & 0.0030 & $\begin{array}{l}-0.5982 \\
\end{array}$ & 0.1748 & 0.0010 \\
\hline Netherlands & -0.0434 & 0.1390 & 0.7550 & 0.2248 & 0.1324 & 0.0900 & 0.3206 & 0.1286 & 0.0130 & 0.8700 & 0.1292 & 0.0000 & -0.8557 & 0.1847 & 0.0000 \\
\hline France & -0.0545 & 0.1374 & 0.6920 & 0.1830 & 0.1314 & 0.1640 & 0.0327 & 0.1249 & 0.7930 & -0.6717 & 0.1305 & 0.0000 & -0.7301 & 0.1704 & 0.0000 \\
\hline Mexico & -0.3541 & 0.1329 & 0.0080 & 0.6057 & 0.1343 & 0.0000 & -1.0720 & 0.1244 & 0.0000 & -1.3444 & 0.1434 & 0.0000 & -1.0516 & 0.1742 & 0.0000 \\
\hline Italy & -0.0535 & 0.1234 & 0.6650 & 0.9064 & 0.1250 & 0.0000 & -0.0995 & 0.1113 & 0.3720 & -0.4537 & 0.1154 & 0.0000 & -0.2743 & 0.1402 & 0.0500 \\
\hline Czech_Republic & 0.4459 & 0.1686 & 0.0080 & 0.7034 & 0.1587 & 0.0000 & -0.0337 & 0.1363 & 0.8050 & -0.9240 & 0.1563 & 0.0000 & -0.8224 & 0.2128 & 0.0000 \\
\hline Sweden & -0.7487 & 0.1500 & 0.0000 & 0.2068 & 0.1525 & 0.1750 & -0.5893 & 0.1426 & 0.0000 & -0.1176 & 0.1448 & 0.4170 & -0.6349 & 0.2097 & 0.0020 \\
\hline Norway & -0.4774 & 0.1346 & 0.0000 & 0.4220 & 0.1368 & 0.0020 & -0.5445 & 0.1237 & 0.0000 & -0.6356 & 0.1305 & 0.0000 & 0.1224 & 0.1525 & 0.4220 \\
\hline Australia & -0.2475 & 0.1368 & 0.0700 & 0.3545 & 0.1356 & 0.0090 & -0.1931 & 0.1249 & 0.1220 & -0.3740 & 0.1276 & 0.0030 & -0.4235 & 0.1561 & 0.0070 \\
\hline Gender_male & -0.0267 & 0.0552 & 0.6280 & 0.0159 & 0.0604 & 0.7930 & -0.0676 & 0.0513 & 0.1870 & -0.0719 & 0.0564 & 0.2020 & 0.0146 & 0.0738 & 0.8430 \\
\hline Status_married & 0.1754 & 0.0579 & 0.0020 & 0.1849 & 0.0624 & 0.0030 & 0.0602 & 0.0547 & 0.2710 & -0.0335 & 0.0604 & 0.5790 & -0.0897 & 0.0781 & 0.2510 \\
\hline Income & 0.0639 & 0.0546 & 0.2420 & 0.0623 & 0.0603 & 0.3010 & 0.1249 & 0.0508 & 0.0140 & 0.0980 & 0.0562 & 0.0810 & 0.0701 & 0.0724 & 0.3330 \\
\hline Age_class_2 & 0.1280 & 0.0806 & 0.1120 & -0.2244 & 0.0875 & 0.0100 & $\begin{array}{l}-0.0466 \\
\end{array}$ & 0.0752 & 0.5350 & -0.0575 & 0.0827 & 0.4870 & 0.1250 & 0.1057 & 0.2370 \\
\hline Age_class_3 & 0.1183 & 0.0762 & 0.1200 & -0.1309 & 0.0848 & 0.1230 & 0.0317 & 0.0711 & 0.6560 & -0.0280 & 0.0775 & 0.7180 & 0.0114 & 0.1008 & 0.9100 \\
\hline Age_class_4 & 0.1587 & 0.0772 & 0.0400 & -0.0219 & 0.0869 & 0.8010 & 0.1505 & 0.0715 & 0.0350 & -0.0368 & 0.0783 & 0.6380 & 0.0897 & 0.1006 & 0.3720 \\
\hline Edu_class_2 & 0.0555 & 0.1032 & 0.5900 & 0.1129 & 0.1091 & 0.3000 & -0.0427 & 0.0934 & 0.6480 & 0.1007 & 0.1052 & 0.3380 & -0.0064 & 0.1424 & 0.9640 \\
\hline Edu_class_3 & -0.0602 & 0.1023 & 0.5560 & -0.0775 & 0.1077 & 0.4720 & -0.1053 & 0.0952 & 0.2690 & 0.1128 & 0.1052 & 0.2840 & -0.0188 & 0.1442 & 0.8960 \\
\hline Edu_class_4 & -0.0581 & 0.1087 & 0.5930 & 0.0000 & 0.1157 & 1.0000 & -0.0965 & 0.1009 & 0.3390 & 0.0480 & 0.1120 & 0.6680 & 0.0380 & 0.1484 & 0.7980 \\
\hline Edu_class_5 & 0.0406 & 0.1214 & 0.7380 & 0.1026 & 0.1307 & 0.4330 & -0.0222 & 0.1115 & 0.8420 & 0.1941 & 0.1238 & 0.1170 & 0.0462 & 0.1621 & 0.7760 \\
\hline Empl_fulltime & -0.0209 & 0.0828 & 0.8000 & 0.0302 & 0.0931 & 0.7460 & -0.2311 & 0.0778 & 0.0030 & 0.1341 & 0.0846 & 0.1130 & 0.0936 & 0.1128 & 0.4070 \\
\hline Empl_parttime & -0.0627 & 0.1023 & 0.5400 & 0.1046 & 0.1159 & 0.3670 & -0.3510 & 0.0966 & 0.0000 & 0.1203 & 0.1042 & 0.2480 & 0.2719 & 0.1357 & 0.0450 \\
\hline Empl_retired & \multicolumn{15}{|c|}{ Dropped due to collinearity of results } \\
\hline Empl_homemaker & \multicolumn{15}{|c|}{ Dropped due to collinearity of results } \\
\hline Empl_leave & 0.4023 & 0.2215 & 0.0690 & 0.1427 & 0.2196 & 0.5160 & 0.0439 & 0.1844 & 0.8120 & 0.2384 & 0.1916 & 0.2140 & 0.0392 & 0.2713 & 0.8850 \\
\hline Occup_professional & 0.1311 & 0.0788 & 0.0960 & 0.1067 & 0.0865 & 0.2170 & 0.1465 & 0.0732 & 0.0450 & 0.1559 & 0.0798 & 0.0510 & 0.1596 & 0.1007 & 0.1130 \\
\hline Occup_executive & -0.0175 & 0.0722 & 0.8090 & 0.1645 & 0.0805 & 0.0410 & 0.1440 & 0.0680 & 0.0340 & 0.1638 & 0.0736 & 0.0260 & 0.2703 & 0.0950 & 0.0040 \\
\hline Occup_selfemployed & 0.0722 & 0.0967 & 0.4550 & 0.1399 & 0.1090 & 0.1990 & 0.1737 & 0.0898 & 0.0530 & 0.1020 & 0.0970 & 0.2930 & -0.0061 & 0.1304 & 0.9630 \\
\hline Occup_salaried & \multicolumn{15}{|c|}{ Dropped due to collinearity of results } \\
\hline Restype_house & 0.2421 & 0.0641 & 0.0000 & 0.2952 & 0.0682 & 0.0000 & 0.2995 & 0.0597 & 0.0000 & 0.2469 & 0.0652 & 0.0000 & 0.3201 & 0.0879 & 0.0000 \\
\hline Area_rural & -0.0179 & 0.0746 & 0.8110 & 0.0962 & 0.0826 & 0.2440 & 0.1017 & 0.0694 & 0.1430 & 0.1095 & 0.0728 & 0.1330 & -0.0289 & 0.0934 & 0.7570 \\
\hline Area_urban & -0.0172 & 0.0621 & 0.7820 & -0.0105 & 0.0679 & 0.8770 & 0.0094 & 0.0577 & 0.8710 & -0.0706 & 0.0636 & 0.2680 & -0.1498 & 0.0843 & 0.0760 \\
\hline Policy_timeofuse & 0.0101 & 0.0567 & 0.8590 & -0.0625 & 0.0615 & 0.3100 & 0.0894 & 0.0524 & 0.0880 & 0.1270 & 0.0570 & 0.0260 & 0.3608 & 0.0774 & 0.0000 \\
\hline _cons & 0.5219 & 0.1686 & 0.0020 & 0.1431 & 0.1726 & 0.4070 & 0.2284 & 0.1549 & 0.1410 & -0.6714 & 0.1663 & 0.0000 & -1.5011 & 0.2189 & 0.0000 \\
\hline
\end{tabular}




\section{REFERENCES}

Abrahamse, W., \& Steg, L. (2009). How do socio-demographic and psychological factors relate to households' direct and indirect energy use and savings? Journal of Economic Psychology, 30, 711-720.

Albadi, M. H., \& El-Saadany, E. F. (2008). A summary of demand response in electricity markets. Electric Power Systems Research, 78, 1989-1996.

Alexander, B. R. (2010). Dynamic Pricing? Not So Fast! A Residential Consumer Perspective. The Electricity Journal, 23(6), 39-49. doi:/10.1016/j.tej.2010.05.014

Axelrod, L. J. \& Lehman, D. R. (1993). Responding to environmental concerns: What factors guide individual actions? Journal of Environmental Psychology, 13, 149-159.

Baladi, S. M., Herriges, J. A., \& Sweeney, T. J. (1998). Residential response to voluntary timeof-use electricity rates. Resource and Energy Economics, 20, 255-244.

Bang, K.-H., Ellinger, E. A., Hadjimarcou, J., \& Traichal, A. P. (2000). Consumer concern, knowledge, belief, and attitude towards renewable energy: An application of the reasoned action theory. Psychology \& Marketing, 17, 449-468.

Barr, S., Gilg, A.W., \& Ford, N. (2005). The household energy gap: examining the divide between habitual-and purchase-related conservation behaviour. Energy Policy, 33, 14251444.

Berkhout, P. H. G., Ferrer-i-Carbonell, A., \& Muskens, J. S. (2004), “The ex post impact of an energy tax on household energy demand", Energy Economics, 26(3), pp. 297-317.

Borenstein, S. (2013). Effective and equitable adoption of opt-in residential dynamic electricity pricing. Review of Industrial Organization, 42, 127-160. 
Cappellari, L., \& Jenkins, S. P. (2003). Multivariate probit regression using simulated maximum likelihood. The Stata Journal, 3, 278-294.

Cayla, J. M., Maizi, N., \& Marchand, C. (2011). The role of income in energy consumption behavior: Evidence from French households data. Energy Policy, 39, 7874-7883.

Chao, H. (2010). Price-responsive demand management for a smart grid world. The Electricity Journal, 23, 7-20. doi:/10.1016/j.tej.2009.12.007

Clark, C. F., Kotchen, M. J., \& Moore, M. R. (2003). Internal and external influences on proenvironmental behavior: Participation in a green electricity program. Journal of Environmental Psychology, 23, 237-246.

Cochell, J. E., Schwarz, P. M., \& Taylor, T. N. (2012). Using real-time electricity data to estimate response to time-of-use and flat rates: an application to emissions. Journal of Regulatory Economics, 42, 135-158.

Curtis, F. A., Simpson-Housley, P., \& Drever, S. (1984). Communications on energy: Household energy conservation. Energy Policy, 12, 452-456.

Dietz, T., Gardner, G.T., Gilligan, J., Stern, P. C., \& Vandenbergh, M. P. (2009). Household actions can provide a behavioral wedge to rapidly reduce US carbon emissions. Proceedings for the National Academy of Sciences, 106(44), 18452-18456. doi: 10.1073/pnas.0908738106

Environmental Commissioner of Ontario (ECO). (2014). 2014 Annual Energy Conservation Progress Report. Planning to Conserve. ECO Publishing. Retrieved February 8, 2015 from http://www.eco.on.ca/uploads/Reports-EnergyConservation/2014/2014\%20Energy\%20Conservation\%20Report\%20Final.pdf 
Faruqui, A., \& Sergici, S. (2010). Household response to dynamic pricing of electricity: a survey of 15 experiments. Journal of Regulatory Economics, 38, 193-225.

Ferrara, I., \& Missios, P. (2012). A Cross-Country Study of Household Waste Prevention and Recycling: Assessing the Effectiveness of Policy Instruments. Land Economics, 88(4), $710-744$.

Gatersleben, B., Steg, L., \& Vlek, C. (2002). Measurement and determinants of environmentally significant consumer behavior. Environment and Behavior, 34, 335-362.

Herter, K. (2007). Residential implementation of critical-peak pricing of electricity. Energy Policy, 35, 2121-2130.

International Energy Agency (IEA). (2011). G-20 Clean Energy, and Energy Efficiency Deployment and Policy Progress. Paris: IEA Publishing. Retrieved March 15, 2015 from http://www.iea.org/publications/freepublications/publication/G20_paper.pdf

International Energy Agency (IEA). (2012). Electricity Information 2012. Paris: IEA Publishing. Retrieved March 15, 2015 from http://www.iea.org/media/training/presentations/statisticsmarch/ElectricityInformation.pd f

John, A. (2000). The relationship between energy consumption, energy prices and economic growth: time series evidence from Asian developing countries. Energy Economics, 22, $615-625$.

Kalafatis, P. S., Pollard, M., East, R., \& Tsogas, H. M. (1999). Green marketing and Ajzen's theory of planned behavior: A cross-market examination. Journal of Consumer Marketing, 16, 441-460. 
Kallbekken, S., Saelen, H., \& Hermansen, E. A. T. (2013). Bridging the energy efficiency gap: A field experiment on lifetime energy costs and household appliances. Journal of Consumer Policy, 36, 1-16.

Kelly, G. (2012). Sustainability at home: Policy measures for energy-efficient appliances. Renewable and Sustainable Energy Reviews, 16, 6851-6860.

Kim, Y., \& Choi, M. S. (2005). Antecedents of Green Purchase Behavior: An examination of collectivism, environmental concern and PCE. Advances in Consumer Research, 32, $592-599$.

Kollmuss, A., \& Agyeman, J. (2002). Mind the gap: Why do people act environmentally and what are the barriers to pro-environmental behavior? Environmental Education Research, 8, 239-260.

Levine, M., Ürge-Vorsatz, D., Blok, K., Geng, L., Harvey, D., Lang, S., Levermore, G., Mongameli A. M., Mirasgedis, S., Novikova, A., Rilling, J., Yoshino, H. (2007). Residential and commercial buildings. In E. Jochem \& H. Xu (Eds.), Climate Change 2007: Working Group III: Mitigation of Climate Change. Cambridge and New York: Cambridge University Press.

Long, J.E. (1993). An econometric analysis of residential expenditures on energy conservation and renewable energy sources. Energy Economics, 15(4), pp 232-238.

Michaelis, L. (2003). Sustainable consumption and greenhouse gas mitigation. Climate Policy, 3S1, S135-S146.

Mostafa, M. M. (2007). A hierarchical analysis of the green consciousness of the Egyptian consumer. Psychology \& Marketing, 24, 445-473. 
Muratori, M., Schuelke-Leech, B., \& Rizzoni, G. (2014). Role of residential demand response in modern electricity markets. Renewable and Sustainable Energy Reviews, 33, 546-553.

Nair, G., Gustavsson, L., \& Mahapatra, K. (2010). Factors influencing energy efficiency investments in existing swedish residential buildings. Energy Policy, 38, 2956-2963.

Natural Resources Canada (NRCan). (2010). Energy Efficiency Trends in Canada 1990 to 2007. Ottawa: NRCan Publishing. Retrieved February 7, 2015 from http://oee.nrcan.gc.ca/publications/statistics/trends09/pdf/trends.pdf

Nesbakken, R. (1999). Price sensitivity of residential energy consumption in Norway. Energy Economics, 21, 493-515.

Newsham, G. R., \& Donnelly, C. I. (2013). A model of residential energy end-use in Canada: Using conditional demand analysis to suggest policy options for community energy planners. Energy Policy, 59, 133-142.

OECD/IEA. (2001). An Initial View on Methodologies for Emission Baselines: Energy Efficiency Case Study. Paris: OECD Environment Directorate. Retrieved March 15, 2015 from http://www.oecd.org/env/cc/2002529.pdf

OECD. (2008 a). (2008). OECD Household Survey on Environmental Attitudes and Behaviour: Data Corroboration. Retrieved December 16, 2014 from http://www.oecd.org/greengrowth/consumption-innovation/44101274.pdf

OECD. (2008 b). Household Behaviour and the Environment: Reviewing the Evidence. Paris: OECD Publishing. Retrieved March 15, 2015 from http://www.oecd.org/environment/consumption-innovation/42183878.pdf

OECD. (2011). Greening Household Behaviour: The Role of Public Policy. Paris: OECD Publishing. doi: 10.1787/9789264096875-en 
Omer, A. M. (2008). Energy, environment and sustainable development. Science Direct, 12, 2265-2300.

Ontario Energy Board (OEB). (2014). Electricity Prices. Retrieved October 6, 2014 from http://www.ontarioenergyboard.ca/OEB/Consumers/Electricity/Electricity+Prices

O’Neill, B. C., \& Chen, B. S. (2002). Demographic determinants of household energy use in the United States. Population and Development Review, 28, 53-88.

Poortinga, W., Steg, L, \& Vlek, C. (2004). Values, Environmental Concern, and Environmental Behaviour. A study into household energy use. Environment and Behaviour, 36, 70-93.

Poortinga, W.; Steg, L.; Vlek, C.; Wiersma, G. (2003). Household preferences for energy-saving measures: A conjoint analysis. Journal of Economic Psychology, 24, 49-64.

Powers, T. L., Swan, J. E., \& Lee, S. D. (1992). Identifying and understanding the energy conservation consumer: A macromarketing systems approach. Journal of Macromarketing, 12, 5-15.

Renner, S., Albu, M., van Elburg, H., Heinemann, C., Lazicki, A., Penttinen, L., Puente, F., \& Saele, H. (2011). European Smart Metering Landscape Report. Vienna: Österreichische Energieagentur - Austrian Energy Agency (AEA). Retrieved from http://www.piio.pl/dok/European_Smart_Metering_Landscape_Report.pdf

Reiss, P. C., \& White, M. W. (2008). What changes energy consumption? Prices and public pressures. The RAND Journal of Economics, 39, 636-663. doi: 10.1111/j.17562171.2008.00032.x

Rowlands, I. H., Scott, D., \& Parker, P. (2003). Consumers and Green Electricity: Profiling Potential Purchasers. Business Strategy and the Environment, 12, 36-48. 
Sardianou, E. (2007). Estimating energy conservation patterns of Greek households. Energy Policy, 35, 3778-3791.

Schahn, J., \& Holzer, E. (1990). Studies of individual environmental concern: The role of knowledge, gender, and background variables. Environment and Behavior, 22, 767-786.

Simshauser, P., Nelson, T., \& Doan, T. (2010). The Boomerang Paradox: how a nation's wealth is creating fuel poverty - and how to defuse the cycle (Working Paper No. 17). Retrieved from AGL Applied Economic \& Policy Research website http://www.aglblog.com.au/wp-content/uploads/2010/10/No.17-Boomerang-ParadoxFinal-Oct-20102.pdf

Smartmeters. (2014). About smart meters. Retrieved October 6, 2014, from http://www.smartmeters.vic.gov.au/about-smart-meters/reports-andconsultations/advanced-metering-infrastructure-cost-benefit-analysis/1.-introduction

Smart Metering Entity (SME). (n.d). History. Retrieved October 6, 2014 from http://www.smiieso.ca/history

Urban, J., \& Scasny, M. (2012). Exploring domestic energy-saving: The role of the environmental concern and background variables. Energy Policy, 47, 69-80.

U.S. Department of Energy (DOE). (2005). Benefits of Demand Response in Electricity Markets and Recommendations for Achieving Them. Retrieved March 15, 2015 from http://energy.gov/sites/prod/files/oeprod/DocumentsandMedia/DOE_Benefits_of_Deman d_Response_in_Electricity_Markets_and_Recommendations_for_Achieving_Them_Rep ort_to_Congress.pdf 
U.S. Energy Information Administration (EIA). (2015). How much energy is consumed in the world by each sector? Retrieved February 7, 2015 from http://www.eia.gov/tools/faqs/faq.cfm?id=447\&t=1

U.S. Energy Information Administration (EIA). (2013). Annual Energy Outlook 2013 with Projections to 2040. Retrieved February 7, 2014 from http://www.eia.gov/forecasts/aeo/pdf/0383(2013).pdf

U.S. Energy Information Administration (EIA). (2008). Emission of Greenhouse Gases in the United States 2007. Retrieved February 9, 2015 from http://www.eia.gov/oiaf/1605/ggrpt/pdf/0573\%282007\%29.pdf

World Bank. (2014). Electric Power Consumption. Retrieved October 7, 2014 from http://data.worldbank.org/indicator/EG.USE.ELEC.KH.PC?page=1

World Energy Council (WEC). (2008). Energy Efficiency Policies around the World: Review and Evaluation. London: World Energy Council Publishing. Retrieved February 17, 2015 from http://www.worldenergy.org/wpcontent/uploads/2012/10/PUB_Energy_Efficiency_Policies_Around_the_World_Review_and_Evaluation_2008_WEC.pdf

Yang, L., Dong, C., Wan, C. L. J., \& Ng, C. T. (2013). Electricity time-of-use tariff with consumer behaviour consideration. International Journal of Production Economics, 402410.

Yuan, C., Liu, S., \& Wu, J., (2010). The relationship among energy prices and energy consumption in China. Energy Policy, 38, 197-207.

Zelezny, L.C.; Chua, P.-P.; Aldrich, C. (2000). Elaborating on gender differences in environmentalism. Journal of Social Issues, 56, 443-457 